PNNL-12257, Rev. 1

\title{
Geologic Data Package for 2001 Immobilized Low-Activity Waste Performance Assessment
}

\author{
S. P. Reidel \\ D. G. Horton
}

December 1999

Prepared for

the U.S. Department of Energy

under Contract DE-AC06-76RLO 1830

Pacific Northwest National Laboratory

Richland, Washington 99352 


\section{DISCLAIMER}

This report was prepared as an account of work sponsored by an agency of the United States Government. Neither the United States Government nor any agency thereof, nor any of their employees, make any warranty, express or implied, or assumes any legal liability or responsibility for the accuracy, completeness, or usefulness of any information, apparatus, product, or process disclosed, or represents that its use would not infringe privately owned rights. Reference herein to any specific commercial product, process, or service by trade name, trademark, manufacturer, or otherwise does not necessarily constitute or imply its endorsement, recommendation, or favoring by the United States Government or any agency thereof. The views and opinions of authors expressed herein do not necessarily state or reflect those of the United States Government or any agency thereof. 


\section{DISCLAIMER}

Portions of this document may be illegible in electronic image products. Images are produced from the best available original document. 


\section{Summary}

This database is a compilation of existing geologic data from both the existing and new immobilized low-activity waste disposal sites for use in the 2001 Performance Assessment. Data were compiled from both surface and subsurface geologic sources. Large-scale surface geologic maps, previously published, cover the entire 200-East Area and the disposal sites. Subsurface information consists of drilling and geophysical logs from nearby boreholes and stored sediment samples. Numerous published geological reports are available that describe the subsurface geology of the area. Site-specific subsurface data are summarized in tables and profiles in this document.

Uncertainty in data is mainly restricted to borehole information. Variations in sampling and drilling techniques present some correlation uncertainties across the sites. A greater degree of uncertainty exists on the new site because of restricted borehole coverage. There is some uncertainty to the location and orientation of clastic dikes across the sites. 



\section{Contents}

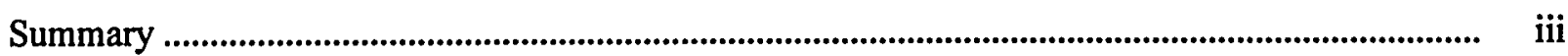

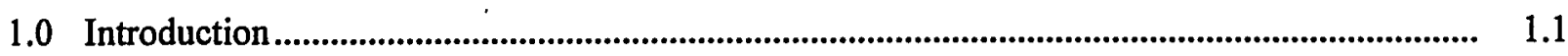

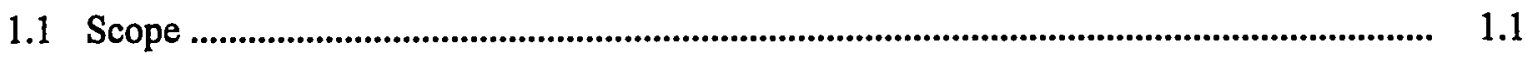

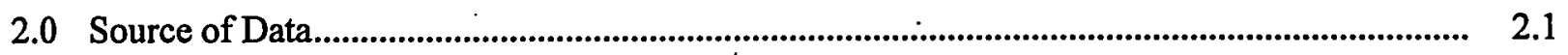

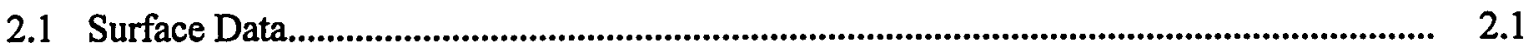

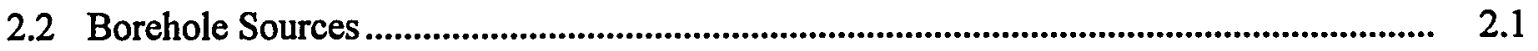

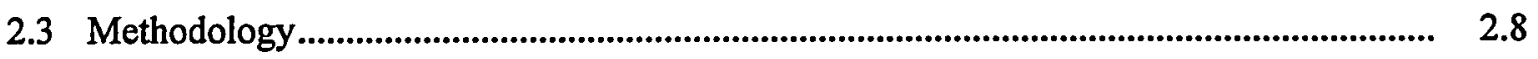

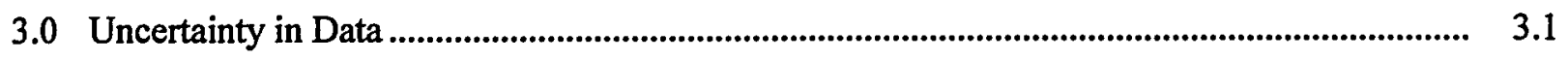

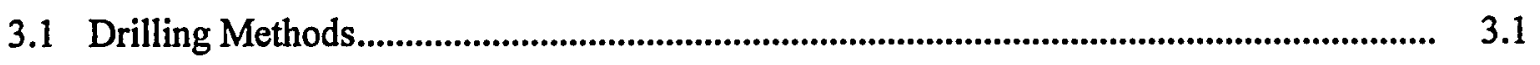

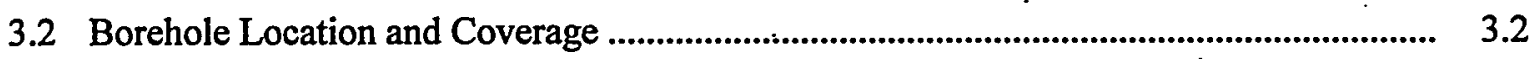

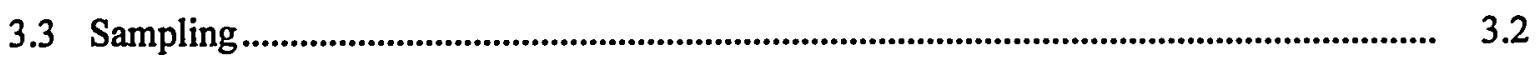

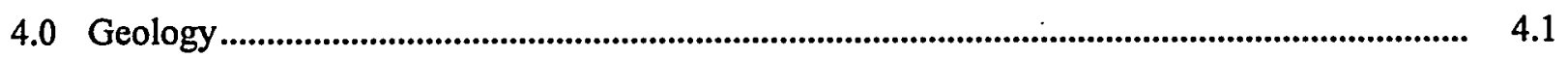

4.1 General Hanford Stratigraphy..................................................................................... 4.1

4.1.1 Surface Geology and Geomorphology ............................................................. 4.1

4.1.2 Subsurface Geology ..................................................................................... 4.1

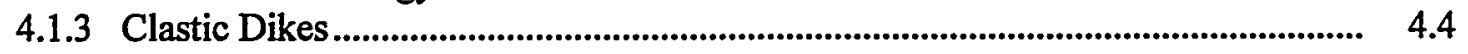

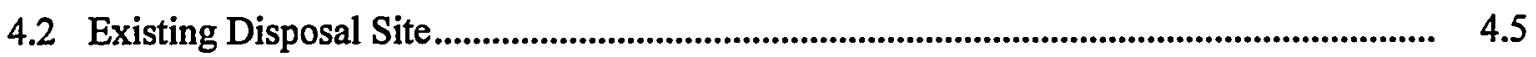

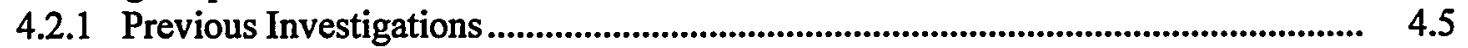

4.2.2 Site Stratigraphy ................................................................................................. 4.6

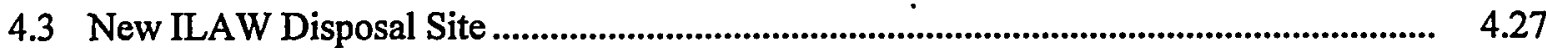

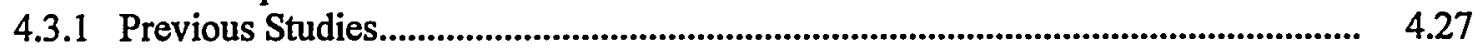

4.3.2 Site Stratigraphy .................................................................................................. 4.27

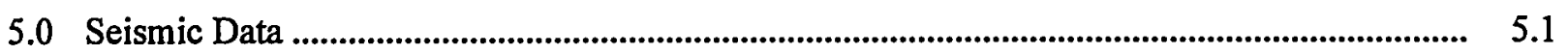

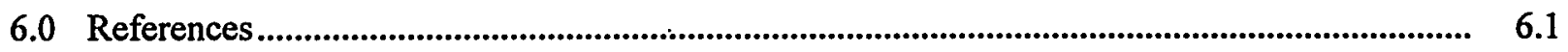

Appendix A - Quality Assurance and Safety.................................................................................. A.1

Appendix B - Paleomagnetic Study ....................................................................................... B.1

Appendix C - Summary Stratigraphic Cross Sections for the Existing and New Immobilized

Low-Activity Waste Disposal Site .............................................................................. C.1 


\section{Figures}

1.1 Location Map of the Existing Disposal Site and the New ILAW Disposal Site .................... 1.2

4.1 Geologic and Geomorphic Map of the 200-East Area .......................................................... 4.2

4.2 Generalized Stratigraphy of the Hanford Site and New ILAW Disposal Site........................ 4.3

4.3 Map of the Existing Disposal Site Showing the Location of Boreholes and Cross-Sections ......................................................................................................................... $4: 7$

4.4 Cross-Section A-A' Across the Existing Disposal Site ................................................. 4.9

4.5 Cross-Section B-B' Across the Southern Part of the Existing Disposal Site .......................... 4.13

4.6 Cross-Section C-C' North of the Existing Disposal Site...................................................... 4.17

4.7 Cross-Section D-D' Across the West Part of the Existing Disposal Site .............................. 4.19

4.8 Generalized Elevation of the Top of the Columbia River Basalt Group Under the 200-East Area

4.9 Structure Contour Map of the Top of the Ringold Formation in the Existing Disposal Site.

4.10 Structure Contour Map of the Top of the Hanford Formation Gravel Sequence in the Existing Disposal Site

4.11 Fence Diagram of the New ILAW Disposal Site and Vicinity

4.12 Map Showing Borehole Locations in the New ILAW Disposal Site and the Locations of Cross-Sections A-A', B-B', B'-B', and C-C'

4.13 Cross-Section A-A' Across the New ILAW Disposal Site

4.14 Cross-Section B-B' Across the New ILAW Disposal Site

4.15 Cross-Section B'-B" Across the New ILAW Disposal Site

4.16 Cross-Section C-C' Across the New ILAW Disposal Site

4.17 Isopach Map of the Ringold Formation at the New ILAW Disposal Site.

4.18 Structural Contour Map on the Surface of the Ringold Formation

4.19 Isopach Map of the Hanford Formation at the New ILAW Disposal Site 


\section{Tables}

2.1 Borehole Information for Some Boreholes in and Adjacent to the Existing Disposal Site..... 2.2

2.2 New ILAW Disposal Site Borehole Database................................................................ 2.5

4.1 Existing ILAW Disposal Site Borehole Database ........................................................... 4.21

4.2 Stratigraphic Information from Boreholes in and Adjacent to the New ILAW

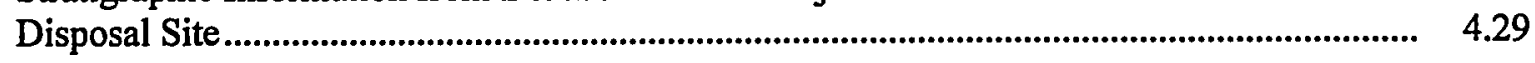

5.1 Earthquakes in the Area Surrounding the Existing and New ILAW Disposal Sites .............. 5.2 


\subsection{Introduction}

The Office of River Protection at the Hanford Site is responsible for safe underground storage of liquid waste from previous Hanford Site operations, storage and disposal of immobilized tank waste, and closure of underground tanks. The current plan is to place immobilized low-activity tank waste (ILAW) in four existing vaults along the east side of 200-East Area and in new facilities in the south-central part of 200-East Area (Figure 1.1) (Mann et al. 1998).

This report is a compilation of geologic information for the existing disposal site and the new ILAW disposal site. This data package is being assembled for the $2001 \mathrm{LAW}$ Performance Assessment (PA). Basic requirements for the ILAW Performance Assessment are defined in Mann et al. (1998). Specific scenarios that will be considered in the 2001 PA are discussed in Mann (1999). These scenarios assume that the main pathway for exposure from the ILAW sites involves water movement into and through the disposal facilities with dissolution of waste followed by transport of contaminants through the vadose zone to the unconfined aquifer and transport in the aquifer to a water supply well. Estimates of possible exposure will be made from predictions of subsurface flow and contaminant transport using numerical simulations. The geologic framework for the numerical model will be developed from this report.

\subsection{Scope}

Data for the 2001 performance assessment will be derived from the following sources:

- Geology. Geologic Data Package for the 2001 Immobilized Low-Activity Waste Performance Assessment (this report).

- Near-Field Hydrology. Near-Field Hydrology Data Package for the Immobilized Low-Activity Waste 2001 Performance Assessment (Meyer and Serne 1999).

- Far-Field Hydrology. Far-Field Hydrology Data Package for the Immobilized Low-Activity Tank Waste Performance Assessment (Khaleel 1999).

- Recharge. Recharge Data Package for the Immobilized Low-Activity Waste 20001 Performance Assessment (Fayer et al. 1999).

- Geochemistry. Geochemical Data Package for the Immobilized Low-Activity Tank Waste Performance Assessment (Kaplan and Serne 1999).

- Inventory. Immobilized Low-Activity Waste Inventory Data Package (Woọtan 1999).

The geology data provided in this report concentrate principally on stratigraphy and structure of the two areas. The mineralogy of sediments and their geochemistry is presented in the geochemistry data 


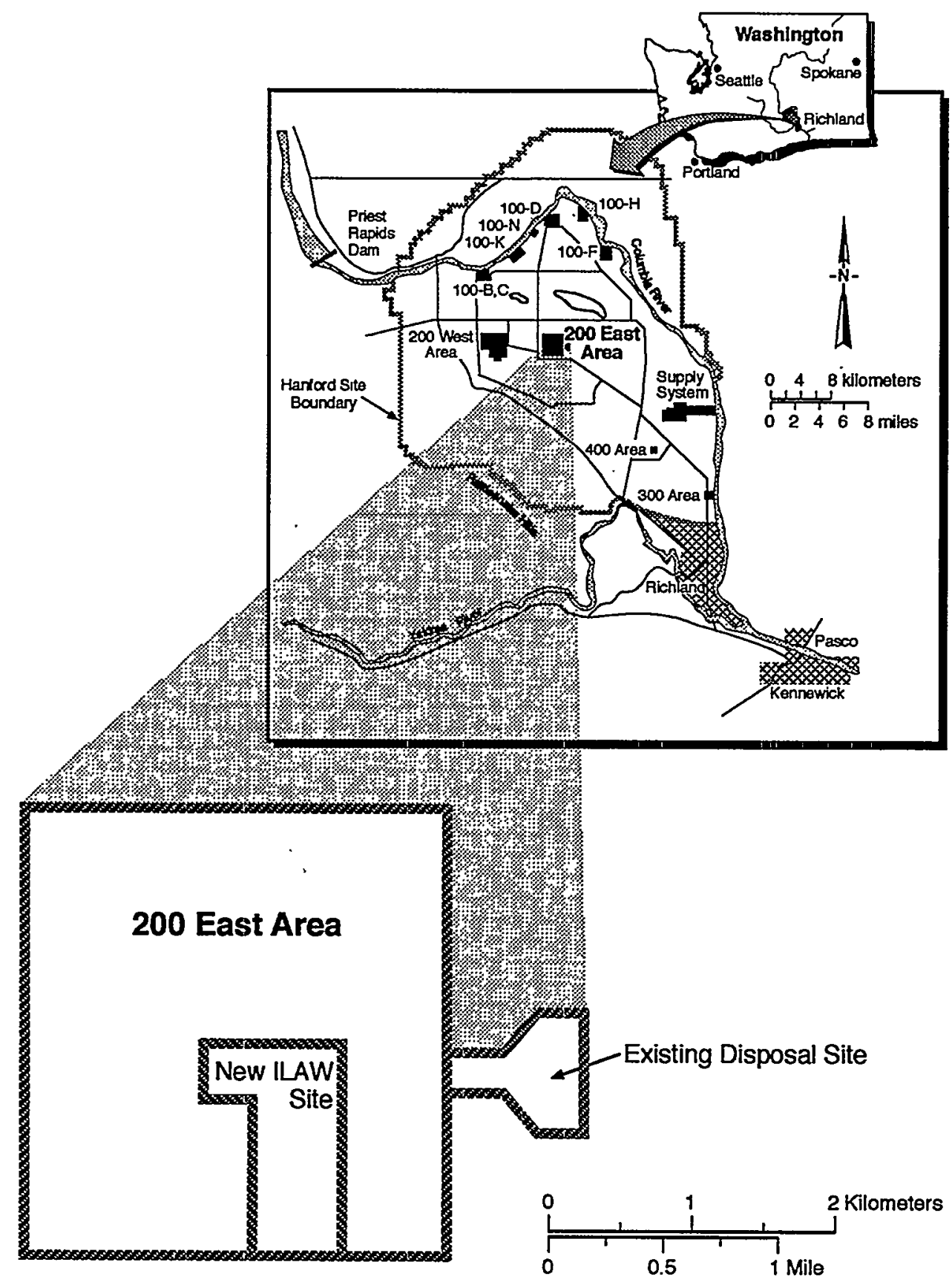

G99060e23.30

Figure 1.1. Location Map of the Existing Disposal Site and the New ILAW Disposal Site 
package. The physical, hydraulic, and transport properties of the soils sediments are presented in the farfield data package and the near-field data package.

This geology data package is a compilation of the basic stratigraphic and structural framework of the two sites and a description of the principal sediments. In addition, this report includes a summary on the sources and uncertainties of the data.

It is beyond the scope of this report to integrate the physical, hydraulic, and transport properties reported in the other data packages. An integration of all the physical, hydraulic, and transport properties of the stratigraphic layers from the ILAW sites will be done in preparation for the numerical simulations for the PA. 


\subsection{Source of Data}

Data used in this compilation was obtained from surface geologic studies and from borehole data.

\subsection{Surface Data}

The surface geology and geomorphology of the Hanford Site has been mapped and published by Reidel and Fecht (1994a, 1994b). The physiography of the Hanford Site is dominated by the low-relief plains of the Central Plains physiographic region and anticlinal ridges of the Yakima Folds physiographic region. Surface topography has been modified within the past several million years by geomorphic processes related to 1) Pleistocene cataclysmic floods, 2) Holocene eolian activity, and 3) landslides.

Cataclysmic flooding of the Hanford Site occurred when ice dams in western Montana and northern Idaho were breached, allowing large volumes of water to spill across eastern and central Washington. The last major flood occurred about 13,000 years ago, during the late Pleistocene Epoch. Anastomosing flood channels, giant current ripples, bergmounds, and giant flood bars are among the landforms created by the floods and are readily seen on Site. Most of the large landslides in the region occurred when these flood waters eroded steep slopes of the anticlinal ridges and along the White Bluffs.

The 200-East Area is located on the Cold Creek bar, one major Pleistocene flood bar. Since the end of the Pleistocene, winds have locally reworked the flood sediments, depositing sand dunes in the lower elevations and loess (windblown silt) around the margins of the Pasco Basin. Sand dunes have generally been stabilized by anchoring vegetation except where the dunes have been reactivated when vegetation is disturbed.

\subsection{Borehole Sources}

Borehole data consisting of drilling logs, archive samples, and geophysical logs provide the principal data used to interpret the subsurface at the existing disposal site and the new ILAW disposal site. In addition, numerous reports describing the geology of the area and vicinity are available and a valuable source of information (e.g., Tällman et al. 1979; DOE 1988; Connelly et al. 1992; Lindberg et al. 1993; Lindsey et al. 1992, 1994b).

Tables 2.1 and 2.2 summarize information about the wells and boreholes used in this report. The north-south and east-west coordinates listed in Tables 2.1 and 2.2 were obtained from the well completion report for each borehole or, if no well completion report was available, from the well location database maintained by Pacific Northwest National Laboratory (PNNL). If several surveys for the same well were found in the database, the most recent survey was used. The specific survey associated with borehole locations obtained from well completion reports is not known but should not affect significantly the information in this data package. 
Table 2.1. Borehole Information for Some Boreholes in and Adjacent to the Existing Disposal Site

\begin{tabular}{|c|c|c|c|c|c|c|c|c|c|c|c|c|c|c|c|}
\hline Borehole \# & $\begin{array}{c}\text { Completion } \\
\text { Date }\end{array}$ & $\begin{array}{c}\text { Lambert } \\
\text { Coordinates } \\
\text { NS/EW (m) }\end{array}$ & $\begin{array}{c}\text { Hanford } \\
\text { Coordinates } \\
\text { NS/EW (ft) }\end{array}$ & $\begin{array}{c}\text { Casing } \\
\text { Elevation } \\
\text { (ft) }\end{array}$ & $\begin{array}{l}\text { NAVD88, } \\
\text { TOC }^{(\boldsymbol{k})}(\mathrm{m})\end{array}$ & $\begin{array}{c}\text { Ground } \\
\text { Surface } \\
\text { Elevation } \\
\text { (ft) (brass } \\
\text { plate) }\end{array}$ & $\begin{array}{c}\text { Total } \\
\text { Depth (f) }\end{array}$ & $\begin{array}{c}\text { Type of } \\
\text { Log }\end{array}$ & $\begin{array}{l}\text { Drilling } \\
\text { Method }^{(\mathfrak{})}\end{array}$ & Sieve & $\mathrm{CaCO}_{3}$ & Moisture & $\begin{array}{c}\text { Gross } \\
\text { Gamma- } \\
\text { Ray Log }\end{array}$ & $\begin{array}{c}\text { Neutron } \\
\text { Log }\end{array}$ & $\begin{array}{c}\text { Drill } \\
\text { Cuttings }\end{array}$ \\
\hline 299-E16-1 & Jan. 1961 & $\begin{array}{l}135219.906 / \\
575782.65\end{array}$ & $38505 /-46303$ & 696.44 & & 694.3 & 510 & Driller & & Yes & & & Yes & & Yes \\
\hline 299-E25-1 & Feb. 1955 & $\begin{array}{l}136031.16 / \\
575366.21\end{array}$ & $41165 /-47759$ & 690.57 & 211.56 & 690.21 & 322 & Driller & $\begin{array}{l}\text { Hard tool } \\
\text { (nom) }\end{array}$ & Yes & & & & & Yes \\
\hline 299-E25-2 & Mar. 1955 & $\begin{array}{l}136062.15 / \\
575513.98\end{array}$ & $41270 /-47190$ & 675.45 & 206.95 & 673.6 & 375 & Driller & $\begin{array}{l}\text { Hard tool } \\
\text { (nom) }\end{array}$ & Yes & & & Yes & & Yes \\
\hline 299-E25-22 & Jun. 1983 & $\begin{array}{l}135609.375 / \\
575998.483\end{array}$ & $\begin{array}{l}39776.4 / \\
-45588.8\end{array}$ & 674.02 & & 671.66 & 295 & Driller & $\begin{array}{l}\text { DB 0 - 190; } \\
\text { HT 191 - 295. }\end{array}$ & Yes & & & & & Yes \\
\hline 299-E25-25 & Apr. 1985 & $\begin{array}{l}135984.406 / \\
576588.887\end{array}$ & $\begin{array}{r}41002.00 / \\
-43648.00\end{array}$ & 699.42 & 205.13 & -672 & 288 & Geologist & $\begin{array}{l}\text { DB 0 - 170; } \\
\text { HT 170-288 }\end{array}$ & Yes & & Yes & Yes & Yes & Yes \\
\hline 299-E25-26 & Apr. 1985 & $\begin{array}{l}135912.861 / \\
575907.504\end{array}$ & $\begin{array}{r}40772.82 / \\
-45884.46\end{array}$ & 668.55 & 204.85 & 668.51 & 290 & Geologist & $\begin{array}{l}\text { DB 0 - 160; } \\
\text { HT 160-205 }\end{array}$ & Yes & & Yes & Yes & & Yes \\
\hline 299-E25-27 & May 1985 & $\begin{array}{l}135633.91 / \\
576136.46\end{array}$ & $\begin{array}{r}39855.23 / \\
-45135.71 \\
\end{array}$ & 676.08 & 207.16 & 674.06 & 300 & Geologist & $\begin{array}{l}\text { DB } 0-155 ; \\
\text { HT } 155-300\end{array}$ & & & Yes & Yes & Yes & Yes \\
\hline 299-E25-28 & Mar. 1985 & $\begin{array}{l}136111.693 / \\
576011.773\end{array}$ & $\begin{array}{r}41424.00 / \\
-45541.00 \\
\end{array}$ & 662.44 & & 660.34 & 348 & Geologist & $\begin{array}{l}\text { DB } 0 \text { - 200; } \\
\text { HT 200 - 348 }\end{array}$ & Yes & & & Yes & & Yes \\
\hline 299-E25-29 & Sept. 1987 & $\begin{array}{l}135729.161 / \\
575953.668 \\
\end{array}$ & $\begin{array}{l}40169.4 / \\
-45734.77\end{array}$ & 672.84 & 206.17 & 672.07 & 336 & Geologist & $\begin{array}{l}\text { DB 40 - 205; } \\
\text { HT 205 - 336 }\end{array}$ & Yes & & & Yes & Yes & Yes \\
\hline 299-E25-30 & Oct. 1987 & \begin{tabular}{|l|}
$135589.913 /$ \\
576208.357
\end{tabular} & $\begin{array}{l}39710.36 / \\
-44900.42\end{array}$ & 678.15 & 207.78 & 677.24 & 330 & Geologist & $\begin{array}{l}\text { DB } 0 \text { - } 178 ; \\
\text { HT } 178-330\end{array}$ & Yes & & & Yes & Yes & Yes \\
\hline 299-E25-31 & July 1987 & $\begin{array}{l}135772.251 / \\
575948.016\end{array}$ & $\begin{array}{l}40311.20 \prime \\
-45752.9\end{array}$ & 674.64 & 206.65 & 671.66 & 298 & Driller & Air rotary & Yes & & & Yes & Yes & Yes \\
\hline 299-E25-32 & Jan. 1988 & $\begin{array}{l}136044.335 / \\
576382.422 \\
\end{array}$ & $\begin{array}{l}41199.17 / \\
-44325.6 \\
\end{array}$ & 670.38 & 205.31 & 668.07 & 354 & Geologist & $\begin{array}{l}\text { DB 0 - } 180 ; \\
\text { HT 180 - 354 }\end{array}$ & Yes & & & Yes & Yes & Yes \\
\hline 299-E25-33 & Jan. 1988 & $\begin{array}{l}135713.014 / \\
575992.033 \\
\end{array}$ & $\begin{array}{l}40116.4 / \\
-45609.0 \\
\end{array}$ & 674.97 & 205.3 & 672 & 400 & Geologist & $\begin{array}{l}\text { DB } 0-190 \\
\text { HT } 190-400\end{array}$ & & & & & & Yes \\
\hline 299-E25-34 & Sept. 1988 & $\begin{array}{l}136100.011 / \\
576019.038\end{array}$ & $\begin{array}{r}41385.90 / \\
-45516.85\end{array}$ & 662.87 & 203.12 & 660.62 & 276 & Geologist & $\begin{array}{l}\text { DB 0 - } 160 ; \\
\text { HT 160-276 }\end{array}$ & & & & & & Yes \\
\hline 299-E25-35 & Aug. 1988 & \begin{tabular}{|l}
$135864.687 /$ \\
575708.338 \\
\end{tabular} & $\begin{array}{r}40616.66 / \\
-46538.50 \\
\end{array}$ & 674.39 & 206.64 & 670.89 & 285 & Geologist & $\begin{array}{l}\text { DB 0-220; } \\
\text { HT 220-285 }\end{array}$ & & & & Yes & Yes & Yes \\
\hline 299-E25-37 & Sept. 1989 & $\begin{array}{l}135818.4 ! \\
575949.2\end{array}$ & $\begin{array}{l}40461.5 / \\
-45749.2\end{array}$ & 673.29 & 206.34 & 670.29 & 280 & Geologist & $\begin{array}{l}\text { DB 0 - 198; } \\
\text { HT 198 - 280 }\end{array}$ & & & & Yes & Yes & Yes \\
\hline
\end{tabular}


Table 2.1. (contd)

\begin{tabular}{|c|c|c|c|c|c|c|c|c|c|c|c|c|c|c|c|}
\hline Borehole \# & $\begin{array}{c}\text { Completion } \\
\text { Date }\end{array}$ & $\begin{array}{c}\text { Lambert } \\
\text { Coordinates } \\
\text { NS/EW (m) }\end{array}$ & $\begin{array}{c}\text { Hanford } \\
\text { Coordinates } \\
\text { NS/EW (ft) }\end{array}$ & $\begin{array}{c}\text { Casing } \\
\text { Elevation } \\
\text { (ft) }\end{array}$ & $\begin{array}{l}\text { NAVD88, } \\
\text { TOC }^{(2)}(\mathrm{m})\end{array}$ & $\begin{array}{c}\text { Ground } \\
\text { Surface } \\
\text { Elevation } \\
\text { (ft) (brass } \\
\text { plate) }\end{array}$ & $\begin{array}{c}\text { Total } \\
\text { Depth }(\mathrm{ft})\end{array}$ & $\begin{array}{l}\text { Type of } \\
\text { Log }\end{array}$ & $\begin{array}{l}\text { Drilling } \\
\text { Method }^{(0)}\end{array}$ & Sieve & $\mathrm{CaCO}_{3}$ & Moisture & $\begin{array}{c}\text { Gross } \\
\text { Gamma- } \\
\text { Ray Log }\end{array}$ & $\begin{array}{c}\text { Neutron } \\
\text { Log }\end{array}$ & $\begin{array}{c}\text { Drill } \\
\text { Cuttings }\end{array}$ \\
\hline 299-E25-38 & Sept. 1989 & $\begin{array}{l}135695.2 / \\
576034.9\end{array}$ & $\begin{array}{l}40056.4 \prime \\
-45469.0\end{array}$ & 673.52 & 206.38 & 670.54 & 283 & Geologist & $\begin{array}{l}\text { DB 0 - 202; } \\
\text { HT 202 - 283 }\end{array}$ & & & & Yes & Yes & Yes \\
\hline 299-E25-39 & Oct. 1990 & $\begin{array}{l}135837.271 \\
576581.88\end{array}$ & $40518 /-43673$ & 671.01 & 205.65 & 668.45 & 282.35 & Geologist & \begin{tabular}{|l}
$\mathrm{DB} 0-207$ \\
$210-262 ; \mathrm{HT}$ \\
$207-210$ \\
$262-282$
\end{tabular} & & Yes & Yes & Yes & Yes & Yes \\
\hline 299-E25-40 & Sept. 1989 & $\begin{array}{l}136212.317 / \\
575464.675\end{array}$ & $\begin{array}{l}41759.6 / \\
-47334.8\end{array}$ & 665.71 & & 662.8 & 274 & Geologist & DB 0-274 & & & & Yes & & Yes \\
\hline 299-E25-41 & Sept. 1989 & $\begin{array}{l}136145.925 / \\
575466.061\end{array}$ & $\begin{array}{r}45541.8 I \\
-47330.9\end{array}$ & 671.26 & & 668.1 & 279 & Geologist & $\begin{array}{l}\text { DB 0 - 225; } \\
\text { HT 225 - 279 }\end{array}$ & & & & Yes & & Yes \\
\hline 299-E25-42 & Aug. 1991 & $\begin{array}{l}135887.6 / \\
575622.8\end{array}$ & $40692 /-46820.1$ & 683.29 & 209.33 & 679.71 & 294.68 & Geologist & $\begin{array}{l}\text { DB 0 - 19; } \\
\text { HT 191- }\end{array}$ & & Yes & Yes & Yes & & Yes \\
\hline 299-E25-43 & Aug. 1991 & $\begin{array}{l}136251.5 / \\
576132.3\end{array}$ & $\begin{array}{l}41881.7 / \\
-45144.9\end{array}$ & 649.89 & 199.15 & 646.52 & 259.7 & Geologist & DB 0-260 & & Yes & Yes & Yes & & Yes \\
\hline 299-E25-44 & Jun. 1992 & $\begin{array}{l}135656.93 / \\
576185.55\end{array}$ & & 675.29 & 206.84 & 672.9 & $293.3^{\circ}$ & Geologist & Air rotary & & Yes & Yes & Yes & Yes & Yes \\
\hline 299-E25-45 & Aug. 1992 & $\begin{array}{l}135659.15 / \\
576185.55\end{array}$ & & 678.45 & 207.81 & 675.74 & 297.65 & Geologist & Air rotary & & Yes & Yes & Yes & Yes & Yes \\
\hline 299-E25-48 & Aug. 1992 & $\begin{array}{l}135815.16 / \\
575623.43\end{array}$ & & 682.31 & 208.98 & 679.68 & 297.5 & Geologist & $\begin{array}{l}\text { Rotary } \\
0-265 ; \text { DB } \\
265-297\end{array}$ & & Yes & Yes & Yes & & Yes \\
\hline 299-E25-49 & Augg. 1993 & $\begin{array}{l}135668.325 / \\
576291.697\end{array}$ & & 678.66 & 207.88 & 675.44 & 293 & Geologist & Air rotary & & Yes & Yes & Yes & Yes & Yes \\
\hline 299-E25-50 & Sept 1993 & $\begin{array}{l}135681.613 / \\
576399.049\end{array}$ & & 677.6 & 207.56 & 675.32 & 294.2 & Geologist & Air rotary & & Yes & Yes & 'Yes & Yes & Yes \\
\hline 299-E25-234 & Sept. 1987 & & $\begin{array}{l}40547.2 / \\
-45618.5\end{array}$ & & & 622 & 141 & Geologist & $\begin{array}{l}\text { SS } 0 \text { - 59 ft; } \\
\text { DB 59 - 141 }\end{array}$ & Yes & & & & & Yes \\
\hline 299-E25-235 & Oct. 1987 & & $40054 /-45185$ & & T & & 174 & Geologist & DB & Yes & & & & & Yes \\
\hline 299-E25-1000 & Oct. 1993 & $\begin{array}{l}135737.654 / \\
576478.436\end{array}$ & & 674.4 & 206.58 & 670.96 & 391.89 & Geologist & Air rotary & & Yes & Yes & Yes & Yes & Yes \\
\hline
\end{tabular}


Table 2.1. (contd)

\begin{tabular}{|c|c|c|c|c|c|c|c|c|c|c|c|c|c|c|c|}
\hline Borehole \# & $\begin{array}{c}\text { Completion } \\
\text { Date }\end{array}$ & $\begin{array}{c}\text { Lambert } \\
\text { Coordinates } \\
\text { NS/EW (m) }\end{array}$ & $\begin{array}{c}\text { Hanford } \\
\text { Coordinates } \\
\text { NS/EW (ft) }\end{array}$ & $\begin{array}{c}\text { Casing } \\
\text { Elevation } \\
\text { (ft) }\end{array}$ & $\begin{array}{l}\text { NAVD88, } \\
\operatorname{TOC}^{(a)}(\mathrm{m})\end{array}$ & \begin{tabular}{|c} 
Ground \\
Surface \\
Elevation \\
(f) (brass \\
plate)
\end{tabular} & Total & $\begin{array}{c}\text { Type of } \\
\text { Log }\end{array}$ & $\begin{array}{l}\text { Drilling } \\
\text { Method }^{(\text {o) }}\end{array}$ & Sieve & $\mathrm{CaCO}_{3}$ & Moisture & $\begin{array}{l}\text { Gross } \\
\text { Gamma- } \\
\text { Ray Log }\end{array}$ & $\begin{array}{c}\text { Neutron } \\
\text { Log }\end{array}$ & $\begin{array}{c}\text { Drill } \\
\text { Cuttings }\end{array}$ \\
\hline 299-E26-12 & Aug. 1991 & $\begin{array}{l}136383.21 \\
576197.7\end{array}$ & & 630.75 & 193.31 & 627.27 & 242.2 & Geologist & DB & & Yes & Yes & Yes & & Yes \\
\hline $699-41-42$ & Feb. 1992 & $\begin{array}{l}136068.171 \\
577122.21\end{array}$ & & 643.91 & & 640.32 & 342.92 & Geologist & Rotary & & Yes & Yes & & & Yes \\
\hline $699-42-42 B$ & Oct. 1988 & $\begin{array}{l}136433.9231 \\
579998.097\end{array}$ & $\begin{array}{l}42472.9 / \\
-42301.3\end{array}$ & 583.23 & & 579.83 & 250 & Geologist & \begin{tabular}{|l|} 
DB 0 - 109, \\
$161-180 ; \mathrm{HT}$ \\
$109-160 ;$ \\
$181-250$
\end{tabular} & Yes & & & Yes & & Yes \\
\hline $699-43-42 \mathrm{~K}$ & Jan. 1989 & $\begin{array}{l}136445.203 / \\
576997.5\end{array}$ & $\begin{array}{l}42509.0 / \\
-42304.3\end{array}$ & 581.38 & & 579.03 & 263 & Geologist & \begin{tabular}{|l|} 
DB $0-111 ;$ \\
HT 112-263
\end{tabular} & & & & Yes & & Yes \\
\hline
\end{tabular}


Table 2.2. New ILAW Disposal Site Borehole Database

\begin{tabular}{|c|c|c|c|c|c|c|c|c|c|c|c|c|c|c|c|}
\hline Borehole \# & $\begin{array}{c}\text { Completion } \\
\text { Date }\end{array}$ & $\begin{array}{c}\text { Lambert } \\
\text { Coordinates } \\
\text { NS/EW (m) }\end{array}$ & $\begin{array}{c}\text { Hanford } \\
\text { Coordinates } \\
\text { NS/EW (ft) }\end{array}$ & \begin{tabular}{|c|} 
Casing \\
Elevation \\
(ft)
\end{tabular} & Quality & \begin{tabular}{|c|} 
Ground \\
Elevation \\
(fi)
\end{tabular} & $\begin{array}{l}\text { Total } \\
\text { Depth } \\
\text { (ft) }\end{array}$ & Type of Log & $\begin{array}{l}\text { Drilling } \\
\text { Method }\end{array}$ & Sieve & $\mathrm{CaCO}_{3}$ & Moisture & \begin{tabular}{|c|} 
Gross \\
Gamma- \\
Ray Log \\
\end{tabular} & $\begin{array}{l}\text { Neutron } \\
\text { Log }\end{array}$ & $\begin{array}{c}\text { Drill } \\
\text { Curtings }\end{array}$ \\
\hline E13-10 & 1984 & $\begin{array}{l}134249.07 / \\
573190.57\end{array}$ & $35348 /-54798$ & 733 & Good & $\mathrm{NA}$ & 346 & Geologist. & Cable tool & & & & & & \\
\hline E17-12 & 1986 & $\begin{array}{l}135118.36 / \\
574902.94\end{array}$ & $38200 /-49180$ & 719 & Good & NA & 340 & Geologist & Cable tool & & & & & & \\
\hline E17-13 & 1986 & $\begin{array}{l}135164.69 / \\
574902.94\end{array}$ & $38352 /-49039$ & 719 & Good & NA & 337 & Geologist & Cable tool & & & & & & \\
\hline E17-17 & 1988 & $\begin{array}{l}135201.571 \\
575044.06\end{array}$ & $38473 /-48717$ & 720 & Good & 717 & 331 & Geologist & Cable tool & & & & Yes & & \\
\hline E17-18 & 1988 & $\begin{array}{l}135115.31 / \\
575109.99\end{array}$ & $\begin{array}{l}38190 / \\
-48500.7\end{array}$ & 721 & Good & 718 & 332 & Geologist & Cable tool & & & & Yes & & \\
\hline E17-20 & 1988 & \begin{tabular}{|l}
$135407.71 /$ \\
574936.49
\end{tabular} & \begin{tabular}{|l|}
$39149.3 /$ \\
-49069.9 \\
\end{tabular} & 719 & Good & 717 & 324 & Geologist & Cable tool & & & & Yes & & \\
\hline E17-21 & 1998 & $\begin{array}{l}134894.21 / \\
574107.02\end{array}$ & NA & 737 & Good & 735 & 480 & Geologist & $\begin{array}{l}\text { Becker } \\
\text { hammer }\end{array}$ & Yes & Yes & Yes & \begin{tabular}{|c|} 
Yes \\
(spectral \\
gamma)
\end{tabular} & Yes & Yes \\
\hline$\overline{E 18-1}$ & 1988 & \begin{tabular}{|l|}
$135197.30 /$ \\
573294.20
\end{tabular} & $38459 /-54458$ & 720 & Good & 716 & 332 & Geologist & Cable tool & Yes & Yes & & Yes & & Yes \\
\hline E18-3 & 1988 & $\begin{array}{l}135274.42 / \\
573426.85\end{array}$ & \begin{tabular}{|l|}
$38712 /$ \\
-54022.8
\end{tabular} & 722 & Good & 718 & 330 & Geologist & Cable tool & Yes & Yes & & Yes & & Yes \\
\hline E18-4 & 1988 & \begin{tabular}{|l|}
$135755.82 I$ \\
573426.48
\end{tabular} & $38651 /-54024$ & 722 & Good & 718 & 330 & Geologist & Cable tool & Yes & Yes & & Yes & & Yes \\
\hline E19-1 & 1957 & \begin{tabular}{|l|}
$135083.31 /$ \\
572817.19
\end{tabular} & $38085 /-56023$ & 736 & Poor & $\overline{N A}$ & 370 & Driller's & Cable tool & & & & Yes & & \\
\hline E23-1 & 1956 & $\begin{array}{l}136011.73 / \\
574043.40\end{array}$ & $41131 /-52000$ & 710 & Fair & $\mathrm{NA}$ & 348 & Driller's & Cable tool & Yes & Yes & & Yes & & Yes \\
\hline$\overline{E 23-2}$ & 1961 & $\begin{array}{l}135667.00 / \\
573738.60\end{array}$ & $\begin{array}{l}40000 / \\
-53000\end{array}$ & 721 & Fair & & 456 & Driller's & Cable tool & & & & Yes & & \\
\hline E24-4 & 1956 & \begin{tabular}{|l|}
$136027.24 I$ \\
575115.44
\end{tabular} & $\begin{array}{l}41181.9- \\
48482.8\end{array}$ & 697 & Fair & NA & 330 & Driller's & Cable tool & & & & Yes & & \\
\hline E24-7 & 1956 & \begin{tabular}{|l|}
$135554.38 /$ \\
574405.20
\end{tabular} & \begin{tabular}{|l|}
$39630.5 /$ \\
-50813
\end{tabular} & 716 & Poor & NA & 450 & Driller's & Cable tool & Yes & Yes & & & & Yes \\
\hline
\end{tabular}


Table 2.2. (contd)

\begin{tabular}{|c|c|c|c|c|c|c|c|c|c|c|c|c|c|c|c|}
\hline Borehole \# & $\begin{array}{c}\text { Completion } \\
\text { Date }\end{array}$ & $\begin{array}{c}\text { Lambert } \\
\text { Coordinates } \\
\text { NS/EW (m) }\end{array}$ & $\begin{array}{l}\text { Hanford } \\
\text { Coordinates } \\
\text { NS/EW (ft) }\end{array}$ & \begin{tabular}{|c|} 
Casing \\
Elevation \\
(ft) \\
\end{tabular} & Quality & $\begin{array}{c}\text { Ground } \\
\text { Elevation } \\
\text { (f) } \\
\end{array}$ & $\begin{array}{l}\text { Total } \\
\text { Depth } \\
\text { (ft) }\end{array}$ & Type of Log & $\begin{array}{l}\text { Drilling } \\
\text { Method }\end{array}$ & Sieve & $\mathrm{CaCO}_{3}$ & Moisture & $\begin{array}{c}\text { Gross } \\
\text { Gamma- } \\
\text { Ray Log }\end{array}$ & $\begin{array}{l}\text { Neutron } \\
\text { Log }\end{array}$ & $\begin{array}{l}\text { Drill } \\
\text { Cuttings }\end{array}$ \\
\hline E24-16 & 1988 & $\begin{array}{l}135456.54 / \\
575016.14\end{array}$ & \begin{tabular}{|c|}
$39309.5 /$ \\
-48808.6
\end{tabular} & 718 & Good & 715 & 329 & Geologist & Cable tool & & & & Yes & & \\
\hline E24-17 & 1988 & \begin{tabular}{|l|}
$135456.32 /$ \\
574936.34 \\
\end{tabular} & \begin{tabular}{|l|}
$39308.8 /$ \\
-49070.4 \\
\end{tabular} & 719 & Good & 716 & 329 & Geologist & Cable tool & & & & Yes & & \\
\hline E24-18 & 1988 & $\begin{array}{l}135463.0 / \\
574645.59\end{array}$ & \begin{tabular}{|l|}
39330.71 \\
-50024.3
\end{tabular} & 719 & Good & 716 & 330 & Geologist & Cable tool & & & & Yes & & \\
\hline E37-47A & 1996 & $\begin{array}{l}34893.261 \\
575556.97\end{array}$ & $\begin{array}{l}37430.58 / \\
47044.23\end{array}$ & 717 & Good & 715 & 525 & Geologist & \begin{tabular}{|l|} 
Air Rotary \\
\end{tabular} & Yes & Yes & Yes & Yes & Yes & Yes \\
\hline
\end{tabular}


Elevation information listed in Tables 2.1 and 2.2 were obtained from well completion reports or as-built diagrams if available, or from Chamness and Merz (1993). Because several different borehole surveys have been used at the Hanford Site over the years, no attempt was made to assure consistency in the elevation survey data. However, differences among surveys are generally small ( $<3$ feet $[1 \mathrm{~m}]$ ) compared to other uncertainties associated with the data (see discussion on uncertainties) and, except for water levels in areas with a relatively flat water table, will not affect significantly the information presented in this database. The well completion dates for the boreholes, the total depths, and the types of boreholes were obtained from well completion reports, as-built diagrams, and Chamness and Merz (1993).

Particle size distribution and calcium carbonate content information are available for some boreholes from the ROCSAN database. The database is no longer maintained but is on file at PNNL. Tables 2.1 and 2.2 indicate the drilling method used for each borehole. ROCSAN data was only considered for intervals in boreholes sampled by drive barrel because hard tool drilling pulverizes the sediments so that results are not representative of actual particle size distribution. The drilling method was obtained from geologists logs, well construction reports, and as-built diagrams for most boreholes. Appropriate particle size distribution data from ROCSAN was used as supplemental textural information but, because of varying data quality, it is not included in this report. The Khaleel (1999) and Fayer et al. (1999) report on particle size data from the two disposal sites are the best compilation of particle size information from the two sites for the ILAW 2001 PA. Meyer and Serne (1999) report similar data on near-field material for the two sites.

Calcium carbonate and moisture contents are available for some boreholes. Available data are in borehole packages on file at PNNL and in the ROCSAN database. The data were obtained from discrete samples collected by the borehole geologist during drilling. Moisture data were used to supplement the geologists log and the gross gamma-ray log in determining lithologic variations. For obvious reasons, moisture data is only valuable for samples collected above the water table. Khaleel (1999) and Fayer et al. (1999) report moisture data from the disposal sites and should be referred to for the best compilation of moisture data from these sites.

Gross gamma-ray logs and neutron moisture logs exist for many of the boreholes used for this report. If at all possible, logs obtained during drilling were used to supplement geologist logs. This is important for moisture measurements because most of the geophysical logs obtained subsequent to borehole completion reflect borehole construction materials more than they do geologic materials. Available logs listed in Tables 2.1 and 2.2 are on file at PNNL.

Finally, drill cuttings are available from most boreholes used for this report. The same precautions pertaining to ROCSAN data pertain to physical samples. That is, drill cuttings obtained from hard tool drilling methods will yield an unrepresentative particle size distribution. Uncertainties in these data are discussed in Section 3.0. All available physical samples are on file in the Hanford Geotechnical Sample Library under custody of PNNL. 


\subsection{Methodology}

The process of building the data package followed a series of steps designed to ensure data were used properly. First, the main stratigraphic units and contacts were identified in boreholes with geologists logs and geophysical data. Gross gamma-ray logs were examined with respect to geologist logs for geophysical signatures of the stratigraphy. For many boreholes from both sites, chip samples from the Hanford Geotechnical Sample Library were examined to help control the location of contacts and lithologies of stratigraphic units and lateral changes in the percentage of silt, sand, and gravel. Next, boreholes with driller's logs and gross gamma-ray logs were examined and compared to nearby wells and boreholes. Lastly, boreholes with only driller's logs were given the least priority for constructing the geologic models. These data were then used to construct the maps and cross sections in Section 4.0. 


\subsection{Uncertainty in Data}

The principal source of uncertainty is in borehole data. Surface mapping is well controlled at Hanford and has been done by geologists with extensive mapping experience at Hanford and in the Columbia Basin. The quality of borehole data is related to drilling technique, logging of the boreholes, and sample collection. Borehole data collection methods (i.e., grab samples) make subtle differences between some stratigraphic units such as silty sandy layers of the Hanford formation and units of the underlying Ringold Formation (e.g., upper Ringold) difficult to identify. The use of geophysical logs is crucial to reducing uncertainty in poor quality driller and geologists logs.

In addition to the uncertainty in borehole data, there is uncertainty in the geometric shape of the sediment body. Lindsey (1996) provides a detailed depositional model for the Ringold Formation but few models are available on the Hanford formation. Borrow pits and excavation sites at Hanford (e.g., FFTF, tank farms, burial grounds, US Ecology) in the Pasco Basin provide information on the geometric shape of a sediment body but boreholes remain the principle means of collecting data to interpret the subsurface.

\subsection{Drilling Methods}

Most boreholes at and near the existing disposal site and the new disposal site have been drilled using cable tool techniques and, less often, air rotary techniques. Only the new ILAW borehole, 299-E17-21, was drilled using the Becker-Hammer technique that allowed high quality core samples to be recovered.

Cable tool drilling has been the standard technique from earliest drilling at Hanford because drilling can be done without adding water; unfortunately, many drillers routinely added water. Drilling techniques include use of drive barrel or hard tool and by driven temporary or permanent casing. The technique generally provides acceptable sample control and has proven successful. More recently, in uncontaminated areas, air rotary has been the preferred technique. Samples obtained from most drilling methods have inherent disadvantages. These disadvantages include:

- Limited sample size. The diameter of the borehole and length of the sampling device control the size of the sample.

- Retention of samples. Dry sediment samples are difficult to retain in any sampling device. This is especially true in drive barrels but also true of core barrels.

- Gravel retrieval. Unconsolidated gravels are not easily retained in drive barrels. Split spoon samples have better success.

- Depth control. Except for cored samples, the exact depth of a sample is not well controlled because part of the sample may be lost or sluffing may occur. 
- Cemented gravels. Cemented gravels or large gravels must be sampled using a "hard tool." All drilling methods requiring hammered drilling and sampling including a split spoon breaks up the sample. Cemented gravels have been successfully cored but some loss is always to be expected.

Most boreholes prior to the 1980 s were drilled without a well-site geologist to log samples. Thus, the only records of early drilling are driller's logs that vary in quality of the sample description. Driller's logs reflect lack of geologic knowledge, detailed descriptions, and accuracy of sampling interval. The quality of the geologists logs also varies from borehole to borehole. For example, a geologist new to the site will recognize the major sediment changes in drill cuttings but may not recognize the subtler changes that also represent changes in stratigraphy. Various procedures used to log sediments can result in different descriptions, which may not be directly comparable to other borehole sample descriptions.

Many boreholes at Hanford were completed without the benefit of being geophysically logged. Geophysical logging can be an important tool for determining lithologic changes. Geophysical logs show subtle lithology differences stemming from differing amounts of natural gamma-ray emitters (most commonly ${ }^{40} \mathrm{~K}$ ). At Hanford, gamma-ray logs typically indicate clay and silt abundance and can provide information on changes in grain size. When geophysical logs are used along with well-site geologist's logs and archived samples, the uncertainty of the depth of lithologic changes is reduced.

\subsection{Borehole Location and Coverage}

Borehole coverage is usually dictated by factors other than just addressing a geologic problem. Therefore, the coverage of boreholes is generally inadequate to address many geologic problems. For the existing disposal site, there is borehole coverage for most of the area because of siting studies for the Grout Treatment project. Borehole coverage is less than adequate for the new ILAW disposal site because there are no existing waste disposal site studies. Borehole data is particularly poor on the east side of the new ILAW disposal site.

\subsection{Sampling}

Sample retrieval is often difficult and sample quantities are limited. Vadose zone drilling is difficult for sample recovery because the samples are typically dry and are not easily retained in the drive barrel. As indicated above, grain size of the sample can also be affected by drilling techniques such as in "hard tool" drilling or sonic drilling.

In order to perform certain tests, samples from several depths often must be composited. Also, certain tests performed on samples in the past may also have destroyed the integrity of the sample. In the past, particle size testing resulted in loss of fines, which were discarded before samples were returned to the Hanford Geotechnical Sample Library. 


\subsection{Geology}

\subsection{General Hanford Stratigraphy}

\subsubsection{Surface Geology and Geomorphology}

Previous studies (DOE 1988) have discussed the general geomorphology of the 200 Areas. These studies describe the 200 Areas as a flood bar (200 Areas plateau) that formed as sediments were deposited by the Missoula floods during Pleistocene. The topographic low area immediately east of 200-East Area is an erosional channel cut by Missoula flood waters that moved south through Gable Gap.

The principal geologic units exposed at the surface are glacial fluvial and eolian sands (Reidel and Fecht 1994a, 1994b) (Figure 4.1). The fluvial sands were deposited by Missoula floods and have since been reworked by westerly winds to form a thin veneer of parabolic dunes.

\subsubsection{Subsurface Geology}

The existing and new disposal sites are in a sequence of sediments that overlie the Columbia River Basalt Group on the north limb of the Cold Creek syncline. These sediments include the upper Miocene to Pliocene Ringold Formation, Pleistocene cataclysmic flood gravels, sands and silt of the Hanford formation, and Holocene eolian deposits (Figures 4.1 and 4.2).

The main nomenclature employed in this report is consistent with the standardized use for the Hanford Site (i.e., Delaney et al. 1991; Reidel et al. 1992; Lindsey et al. 1994a, 1994b; Lindsey 1996) and the new ILAW disposal site (Reidel et al. 1998). Subdivision of some units is inconsistent across the sites because of the difficulty in correlating beds over great distances. Following geologic convention, the discussion in this report proceeds from oldest to youngest units. In addition, this report will use feet rather than meters following the convention used in borehole data.

Rocks underlying the 200-East Area consists of the Elephant Mountain Member of the Saddle Mountains Basalt, Columbia River Basalt Group overlain by the Ringold Formation and the Hanford formation. The Elephant Mountain Member consists of two lava flows totaling approximately $100 \mathrm{ft}(30 \mathrm{~m})$ in thickness and forms the base of the unconfined aquifer at 200-East Area.

The Ringold Formation consists of fluvial and lacustrine sediments deposited by the ancestral Columbia and Clearwater-Salmon river systems between about 3.4 and 8.5 Ma. Lindsey (1996) described the Ringold Formation in terms of three informal members: 1) the member of Wooded Island, 2) the member of Taylor Flat, and 3) the member of Savage Island. Of these, only the member of Wooded Island is present beneath the 200-East Area (Figure 4.2). 


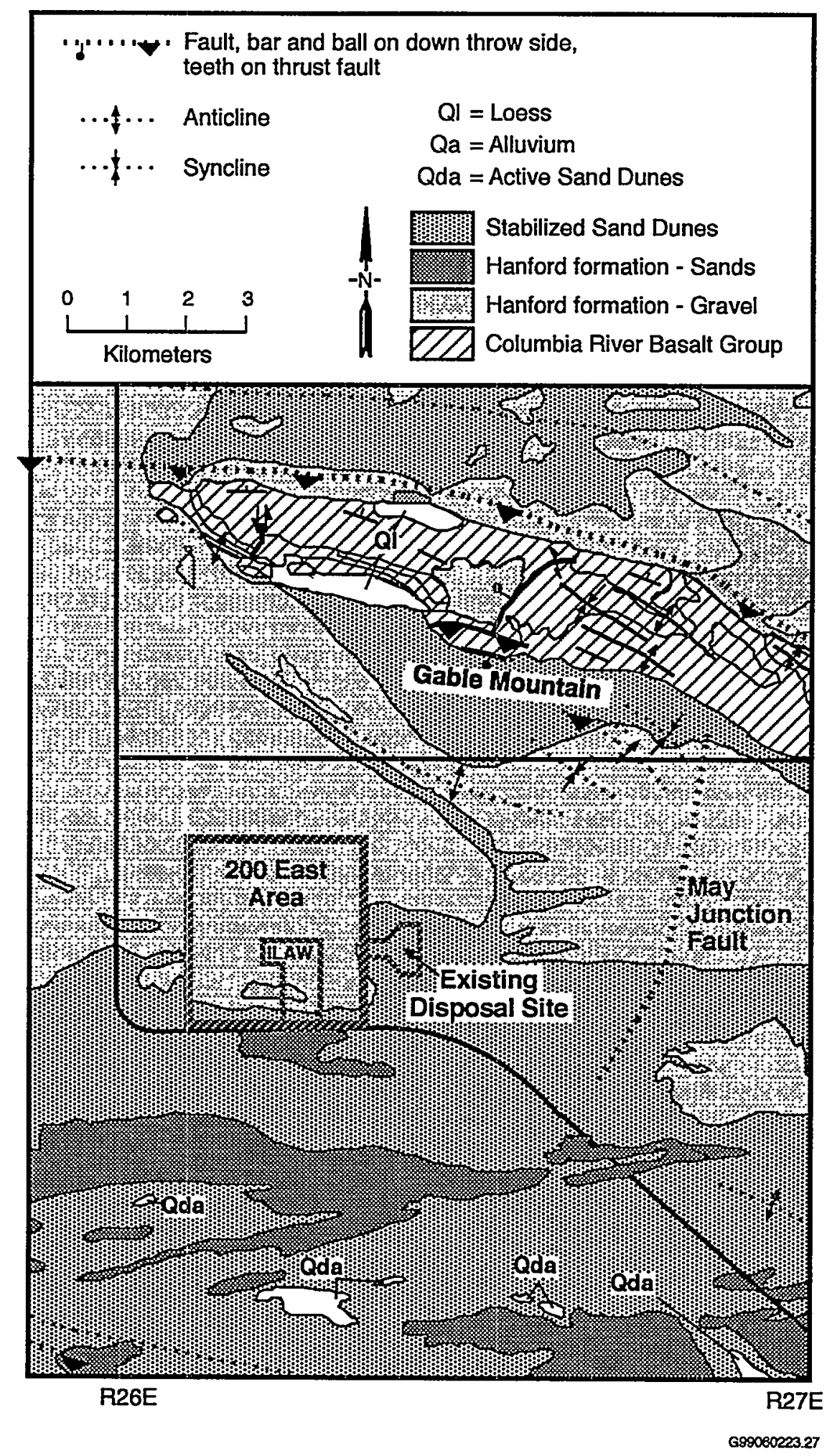

Figure 4.1. Geologic and Geomorphic Map of the 200-East Area (dashed geologic structures indicate they are buried by younger units) (From Reidel and Fecht [1994a, 1994b]) 


\begin{tabular}{|c|c|c|c|}
\hline \multicolumn{2}{|c|}{$\begin{array}{c}\text { Nomenclature Used in this } \\
\text { Report }\end{array}$} & $\begin{array}{l}\text { Equivalent of Lindsey et al. } \\
\text { (1994a), Lindsey (1996), and } \\
\text { Reidel et al. (1992) }\end{array}$ & $\begin{array}{c}\text { Equivalent of } \\
\text { Reidel and Fecht } \\
(1994 a, 1994 b)\end{array}$ \\
\hline \multicolumn{2}{|l|}{ Eolian } & & $\mathrm{Qd}$ \\
\hline \multicolumn{2}{|c|}{ Hanford formation } & $\mathrm{H}$ & Qfs and Qfg \\
\hline \multirow{3}{*}{$\begin{array}{l}\text { Sandy } \\
\text { Sequence }\end{array}$} & Layer 3 & $\mathrm{H} 2$ & $\mathrm{Qfs}_{3}$ \\
\hline & Layer 2 & $\mathrm{H} 2$ & $\mathrm{Qfs}^{2}$ \\
\hline & Layer 1 & $\mathrm{H} 2$ and $\mathrm{HZA}$ & $\mathrm{Qfs}_{1}(?)$ \\
\hline \multicolumn{2}{|c|}{ Basal Gravel Sequence } & $\mathrm{H} 3$ & $\mathrm{Qfs}_{1}(?)$ \\
\hline \multicolumn{2}{|c|}{$\begin{array}{l}\text { Ringold Formation, Member } \\
\text { of Wooded Island }\end{array}$} & $\begin{array}{l}\text { Ringold Formation, Member } \\
\text { of Wooded Island }\end{array}$ & $\mathrm{P}_{\mathrm{L}} \mathrm{M}$ \\
\hline & Unit E & Unit E & $P_{L} A c g$ \\
\hline & Lower-Mud & Lower Mud & $P_{L} A M c$ \\
\hline & Unit A & Lower A & $P_{L} A c g$ \\
\hline
\end{tabular}

Figure 4.2. Generalized Stratigraphy of the Hanford Site and New ILAW Disposal Site

The member of Wooded Island consists of five separate units dominated by fluvial gravels (conglomerate). The gravels are designated (from bottom to top) as units $\mathrm{A}, \mathrm{B} / \mathrm{D}, \mathrm{C}$, and $\mathrm{E}$. The gravel units are separated by fine-grained deposits typical of overbank and lacustrine environments. The lowermost of the fine-grained sequences is designated the lower mud unit. Only gravel units $A$ and $E$ are present beneath the 200-East Area and the Ringold Formation is entirely absent beneath the north and northeast parts of the 200-East Area (Lindsey et al. 1992, 1994b).

The Ringold Formation conglomerate is a variably indurated clast- and matrix-supported, pebble to cobble gravels with a fine to coarse sand matrix (Lindsey 1996). The most common lithologies are basalt, quartzite, and intermediate to felsic volcanics. Interbedded lenses of silt and sand are common. Cemented zones within the gravels are discontinuous and of variable thickness. In outcrop, the gravels are massive, planer bedded, or cross-bedded. Lying above the Ringold gravels are silts and sands of the upper Ringold, the member of Taylor Flats, which is not generally present beneath the 200-East Area.

The Hanford formation overlies the Ringold Formation. The Hanford formation consists of glaciofluvial sediments deposited by cataclysmic floods from Glacial Lake Missoula, Pluvial Lake Bonneville, and ice-margin lakes. Hanford formation sediments resulted from at least four major glacial events and were deposited between about $1 \mathrm{Ma}$ and $13 \mathrm{Ka}$. The formation consists of pebble- to boulder-gravel, fineto coarse-grained sand, and silt- to clayey-silt. These deposits are divided into three facies: 1) graveldominated facies, 2) sand-dominated facies, and 3) silt-dominated facies (Reidel et al. 1992; Lindsey et al. 1992, 1994a, 1994b). These same facies are referred to as coarse-grained deposits, plane-laminated sand facies, and rhythmite facies, respectively, in Bjornstad et al. (1987) and Baker et al. (1992). The Hanford formation is present throughout the Hanford Site and is as much as $380 \mathrm{ft}(116 \mathrm{~m})$ thick (Delaney et al. 1991). 
- Gravel-dominated facies - This facies generally consists of coarse-grained basaltic sand and granule to boulder gravel. These deposits display an open framework texture, massive bedding, plane to lowangle bedding, and large-scale planar cross bedding in outcrop. Silt content is variable and local interbedded silt and clay have been observed in outcrop. Clay and silt have been found as coatings on clasts but generally not filling open spaces between clasts. The gravel-dominated facies was deposited by high-energy floodwaters in or immediately adjacent to the main cataclysmic flood channelways.

- Sand-dominated facies - This facies consists of fine- to coarse-grained sand and granule gravel. The sands typically have a high basalt content and are commonly referred to as black, gray, or salt-andpepper sands (Lindsey et al. 1992). They may contain small pebbles and rip-up clasts, pebble-gravel interbeds, and silty interbeds less than $3 \mathrm{ft}(1 \mathrm{~m})$ thick. The silt content of the sands is variable, but where it is low a well-sorted and open framework texture is common. The sand facies was deposited adjacent to main flood channelways during the waning stages of flooding. The facies is transitional between the gravel-dominated facies and the silt-dominated facies.

- Silt-dominated facies - This facies consists of thin bedded, plane-laminated and ripple crosslaminated silt and fine- to coarse-grained sand. Beds are typically a few centimeters to several tens of centimeters thick and commonly display normal grading (Myers et al. 1979; Bjornstad et al. 1987; DOE 1988). Local clay-rich beds occur in the silt-dominated facies and paleosols have been observed in core from the 200-East Area. Sediments of this facies were deposited under slack water conditions and in back flooded areas (DOE 1988).

\subsubsection{Clastic Dikes}

Clastic dikes are vertical to subvertical sedimentary structures that cross cut normal sedimentary layering and could effect the vertical movement of water and contaminants. Clastic dikes are a common geologic feature of Pleistocene flood deposits of the Hanford formation although they also have been found in the underlying Ringold Formation and in Columbia River Basalt Group and intercalated sedimentary interbeds. Clastic dikes at Hanford have been described in detail by Fecht et al. (1998).

Clastic dikes typically occur in swarms and occur as regular-shaped polygonal-patterns; irregularshaped polygonal-patterns; pre-existing fissure fillings; and random occurrences. Regular polygonal networks resemble 4- to 8-sided polygons. Dikes in irregular-shaped polygon networks are generally crosscutting in both plan and cross-section resulting in extensive segmentation of the dikes. Where zones of pre-existing weakness occur, clastic dikes often occur in these zones.

Clastic dikes typically show a wide range in widths, depths, and lengths. The vertical extent of clastic dikes has been observed to range from $30 \mathrm{~cm}$ to greater than $55 \mathrm{~m}$. Clastic dike widths ranges from about $1 \mathrm{~mm}$ to greater than $2 \mathrm{~m}$ and their length varies from as little as $0.3 \mathrm{~m}$ to more than $100 \mathrm{~m}$.

In general, a clastic dike is composed of an outer skin of clay with coarser infilling material. Clay linings are commonly $0.03 \mathrm{~mm}$ to $1.0 \mathrm{~mm}$ thick, but linings up to about $10 \mathrm{~mm}$ are known. The clay skins may have a great influence on transport both within and adjacent to the clastic dikes. The width of 
individual infilling layers range from as little as $0.01 \mathrm{~mm}$ to more than $30 \mathrm{~cm}$ and their length can vary from about $0.2 \mathrm{~m}$ to more than $20 \mathrm{~m}$. Infilling sediments are typically poor to well-sorted sand, but may contain clay, silt, and gravel.

Clastic dikes have been noted in the Hanford formation sand sequence in the existing disposal site (Lindberg et al. 1993) and are suspected to occur but have not been identified at the new disposal site. At the existing disposal site, clastic dikes have not been mapped and their number and distribution are not known. Clastic dikes have been found in numerous locations on the 200 Area plateau where they occur primarily in polygonal networks with dimensions ranging from 30 to $240 \mathrm{~m}$ (Fecht et al. 1998). The total depth of the clastic dikes in the existing disposal site is also unknown but they extend below the bottom of the excavations for the former Grout Treatment Facility (Lindberg et al. 1993).

\subsection{Existing Disposal Site}

\subsubsection{Previous Investigations}

In 1988, Swanson et al. reported the existing knowledge of the subsurface geology of the existing disposal site area. Their report included geologic cross-sections, available particle size distribution data, chemical analyses of 47 sediment samples from boreholes, and sediment moisture data.

Swanson (1992) published the borehole completion package containing all known data from the then new RCRA borehole 299-E25-39 within the existing disposal facility. A gross gamma-ray borehole log, moisture and $\mathrm{CaCO}_{3}$ contents, and a geologists $\log$ are included in that report. Similar reports are available for boreholes 299-E25-37 and 299-E25-38 (Swanson 1993) and boreholes 299-E25-49, -50, and -1000 (Swanson 1994).

Lindberg et al. (1993) updated Swanson's description of the geology and aquifer characteristics of the Grout Disposal site (now the existing disposal facility area). Using geologic logs from approximately 45 groundwater wells in the Grout Facility - B Pond - 241-A, AX area, they produced a set of isopach and structure contour maps for each of the geologic units in their interpretation of the subsurface geology. They also provided two cross-sections through the existing disposal site.

Rockhold et al. (1993) estimated the hydraulic properties of material and sediments that determine the movement of water at the existing disposal facility area. They present particle size, bulk density, and particle density data from selected samples from borehole 299-E25-234 in the existing disposal facility.

In 1998, the TWRS Phase 1 Privatization Site Preconstruction Characterization Report (Mitchell 1998) was issued for the existing disposal site and planned glass melter. That report included ground penetrating radar and electromagnetic induction surveys, and borehole geophysical surveys (spectral gamma-ray and neutron-moisture surveys): Unfortunately, most of the neutron moisture surveys from the existing disposal site are of little use because they reflect borehole construction characteristics rather than geologic characteristics. 
Surface geophysical surveys reported by Mitchell (1998) for the existing disposal site interrogated the subsurface to a depth of about $13 \mathrm{ft}(4 \mathrm{~m})$. Most of the upper $13 \mathrm{ft}(4 \mathrm{~m})$ of the existing disposal facility area consisted of homogeneous sediment interpreted as wind blown Holocene sands and silts. In some areas, however, stratification was observed similar to what is found in inactive sand dunes or possibly the finer sediments of the Hanford formation (Mitchell 1998). In one area, geologically complex stratification was noted where soil stratification was laterally discontinuous possibly, in part, due to clastic dikes (Mitchell 1998). Several clastic dikes were noted in the excavation for the former Grout Treatment Facility.

\subsubsection{Site Stratigraphy}

Data reported in this document were compiled from 32 boreholes and monitoring wells in and around the existing disposal site. Figure 4.3 shows the location of the boreholes. Table 4.1 is a listing of the boreholes used along with their location, elevation, and construction information pertinent to this report. For this report, boreholes within the existing disposal facility are considered most important. The boreholes outside the existing disposal facility are used to supplement those within the existing disposal facility.

Six lithologic sequences are identified in this data package for performance assessment purposes. These are (from youngest to oldest):

- Recent surface deposits

- Hanford formation sand sequence

- Hanford formation gravel sequence

- Ringold Formation fine-grain sequence at top of Unit A

- Ringold Formation Unit A

- Columbia River Basalt Group.

The vadose zone beneath the existing disposal site is from approximately $250 \mathrm{ft}(76 \mathrm{~m})$ to $277 \mathrm{ft}$ $(84 \mathrm{~m})$ thick. The vadose zone thins toward the northeast due to a decrease in elevation in that direction and an increase in the elevation of the water table beneath $B$ Pond. With a few exceptions, the water table is in the Ringold Formation fine-grained sequence or just above the sequence in the Hanford formation gravel sequence.

Figure 4.3 shows the locations of the wells in the existing disposal site that were used to interpret the geology and construct the four cross-sections given in Figures 4.4 through 4.7. The cross sections depict the relationships of the lithologic sequences. All data used in constructing the cross sections (and the structure contour maps presented later) are given in Table 4.1. Appendix C provides a more generalized north-south and east-west cross sections depicting the primary features of the area.

The location of cross-section A-A' was chosen to illustrate the geology across the center of the existing disposal site. The exact location was influenced by the locations of existing and newer groundwater wells with the maximum of quality data. The location of cross-section B-B' was chosen to illustrate the geology along the southern portion of the existing disposal site. Likewise, the location of C-C' was 


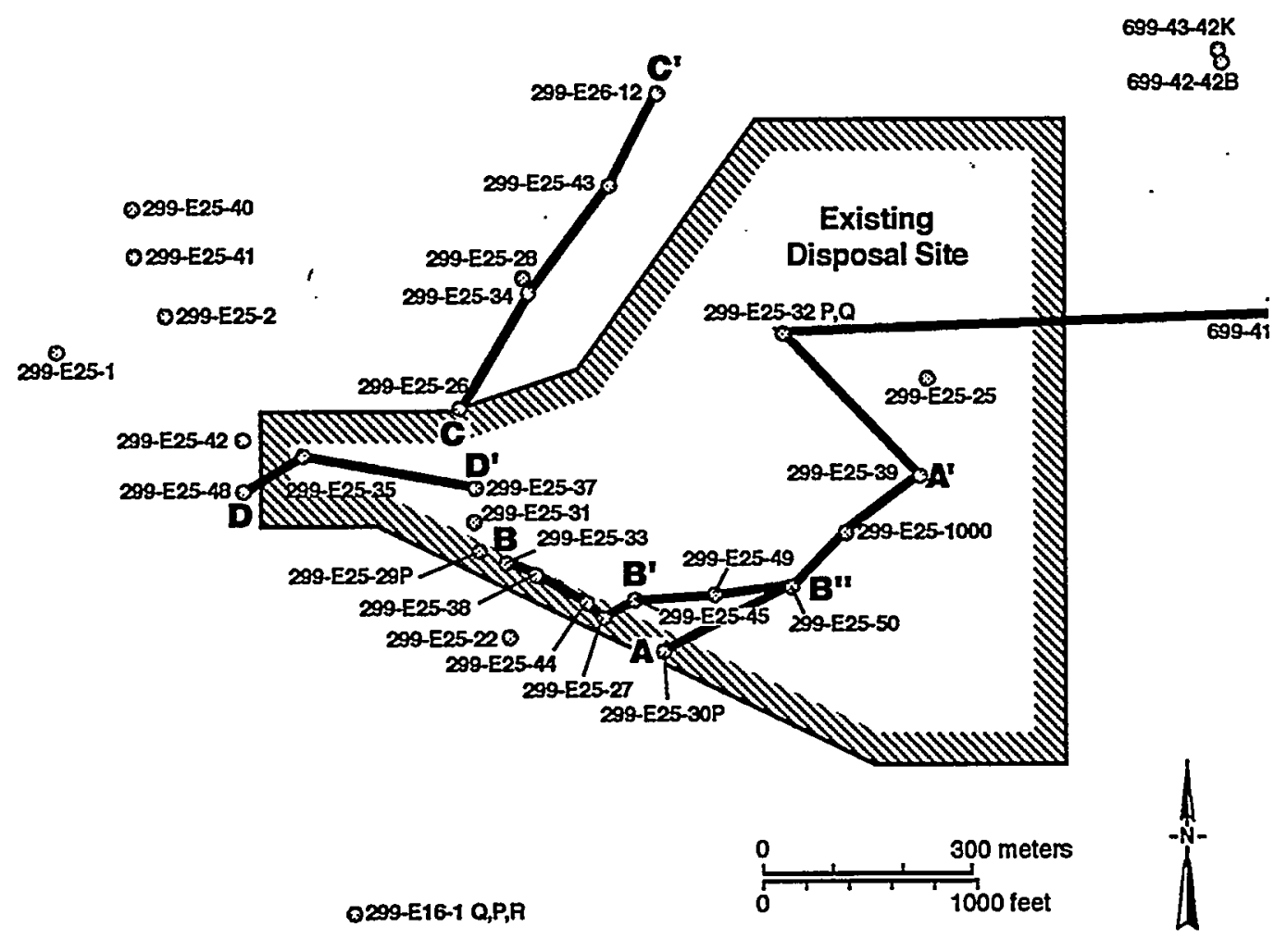

G99080223.18

Figure 4.3. Map of the Existing Disposal Site Showing the Location of Boreholes and Cross-Sections

chosen to illustrate the geology along the northwestern edge of the site. The lack of suitable wells along the northern edge precluded extending the cross-section in that direction. Finally, cross-section D-D' is to illustrate the geology through the center of the waste transfer corridor.

\subsubsection{Columbia River Basalt Group}

The Elephant Mountain Member of the Saddle Mountains Basalt, Columbia River Basalt Group underlies the Ringold Formation. The top of the Elephant Mountain Member was penetrated in only 6 boreholes in the existing disposal facility area. A top of basalt map is shown in Figure 4.8.

\subsubsection{Ringold Formation Unit A}

The Ringold Formation Unit A overlies the Columbia River Basalt Group. This unit is equivalent to the Ringold Formation Unit A described in Lindberg et al. (1993).

The Ringold Formation Unit $A$ is described on borehole logs of cuttings and samples as gravel, sandy gravel, and slightly sandy gravel to muddy sandy gravel at the existing disposal site. The gravels are 
generally poorly sorted, subangular to rounded, and consist of pebbles and cobbles in a sand and mud matrix. Calcium carbonate is common but not abundant. These sediments are interpreted to represent fluvial gravels and sands.

Based on observations of outcrop and intact core, the Ringold Formation Unit A fluvial gravels consist of clast- and matrix-supported, pebble- to cobble-conglomerate with a fine- to coarse-sand matrix and interbedded fine- to coarse-sand and silt lenses (Lindsey 1996). The cement content ranges from absent to well developed. Cemented Ringold Formation conglomerates are discontinuous zones of variable thickness. The conglomerates exhibit massive, planer, and cross-bedding. Clast imbrication is common in the stratified sediments (Lindsey 1996).

Intercalated in the Ringold conglomerates are laterally discontinuous, fine- to coarse-grained, crossbedded sand interbeds. Also interbedded in the conglomerates are thin, variably colored silty deposits, typically with disrupted bedding (Lindsey 1966).

The Ringold Formation Unit A is interpreted to represent rapid deposition of fluvial bed-load sediment in shallow channels across a gravelly floodplain.

The total thickness of the Ringold Formation Unit A at the existing disposal site is not known in most boreholes because most boreholes terminate before penetrating the lower contact. The lower contact is known, however, in 6 boreholes in the existing disposal facility area. In these boreholes, the Ringold Formation Unit A ranges from 55 to $100 \mathrm{ft}$ (17 to $30 \mathrm{~m}$ ) thick with an average thickness of $78 \mathrm{ft}(23.7 \mathrm{~m})$.

\subsubsection{Ringold Formation Fine-Grained Sequence at Top of Unit A}

A fine-grained sequence occurs as the uppermost Ringold Formation sediments in the existing disposal facility area. This sequence, along with the underlying gravels, is equivalent to the Ringold Formation Unit A described by Lindberg et al. (1993) and may be equivalent to a portion of the Ringold Formation Lower Mud. However, facies distribution maps shown in Lindberg et al. (1993) indicate that the Lower Mud has been eroded from most of the area beneath the existing disposal facility so that, if the Lower Mud is present, it is found only as erosional remnants.

The fine-grained sequence is described on borehole logs of cuttings and samples as sand and silty sand with minor silt/clay beds. The sequence is unconsolidated and generally lacks significant cement although it commonly has a variable but often strong reaction with $\mathrm{HCl}$. On borehole logs, internal stratification and other internal features generally are not noted; however, the drilling method used to collect the samples has probably destroyed any internal structure that existed. The fine-grained sequence is represented by an increase in activity on the gross gamma-ray log from most but not all boreholes where it is present. The fine-grained sequence is interpreted to be fluvial sand deposits; possibly, bedload deposits and/or proximal overbank deposits.

The fine-grained sequence varies in thickness from 0 to $27 \mathrm{ft}$ ( 0 to $8 \mathrm{~m})$ with an average thickness of $18 \mathrm{ft}(5.5 \mathrm{~m})$. The sequence is absent in boreholes 299-E25-25, $-28,-31,-37,-42$, and -43 . 


\section{A
Southwest}

\section{9-E25-30P}

El. 677

Drilled

(Feet) CZSG

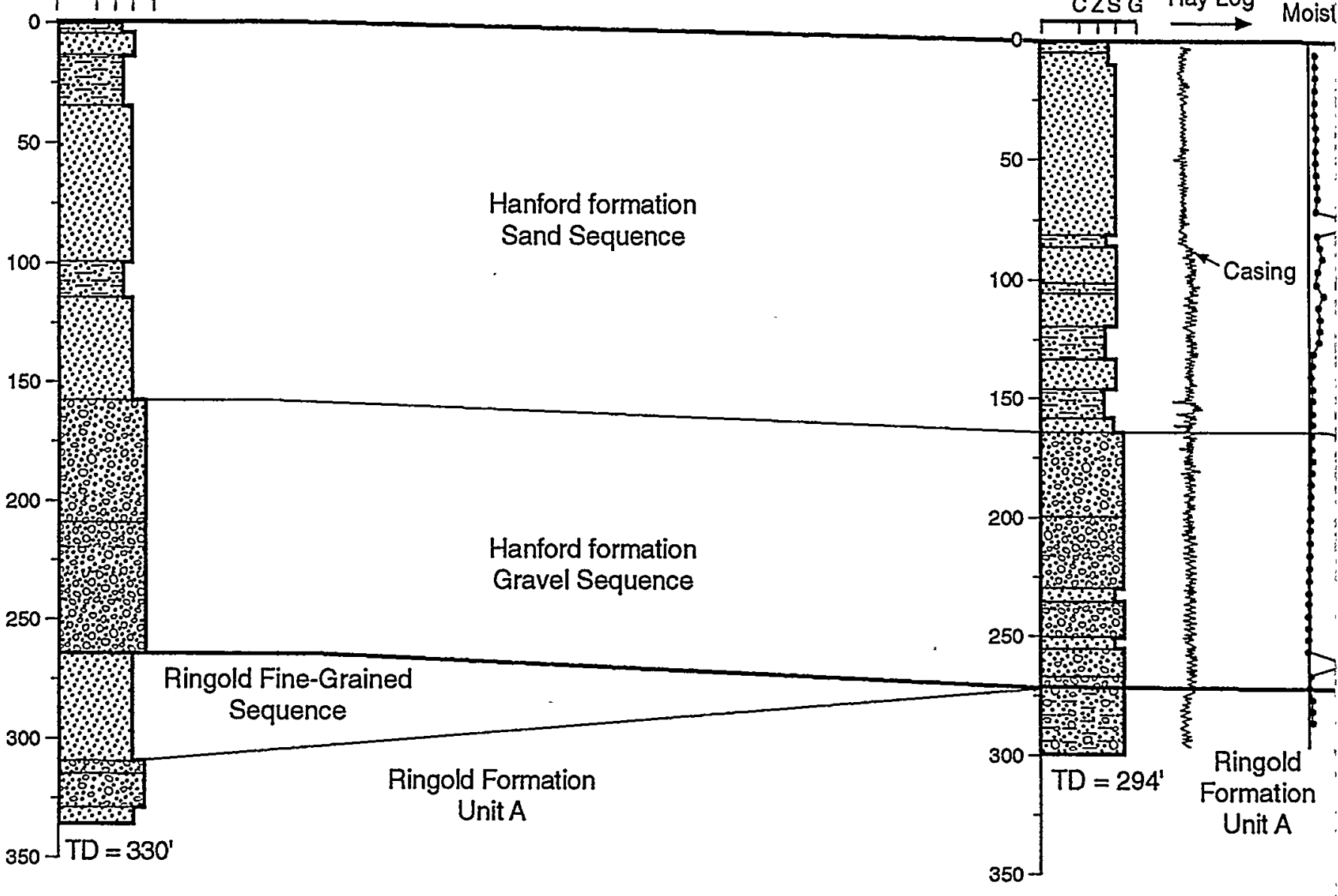

299-E25-50

El. $675^{\prime}$
Gross

Gamma -

Ray Log

Figure 4.4. Cross-Section A-A" 


\section{$A^{\prime}$ \\ Southwest}

299-E25-39

El. 688'
299-E25-32

.El. $668^{\prime}$

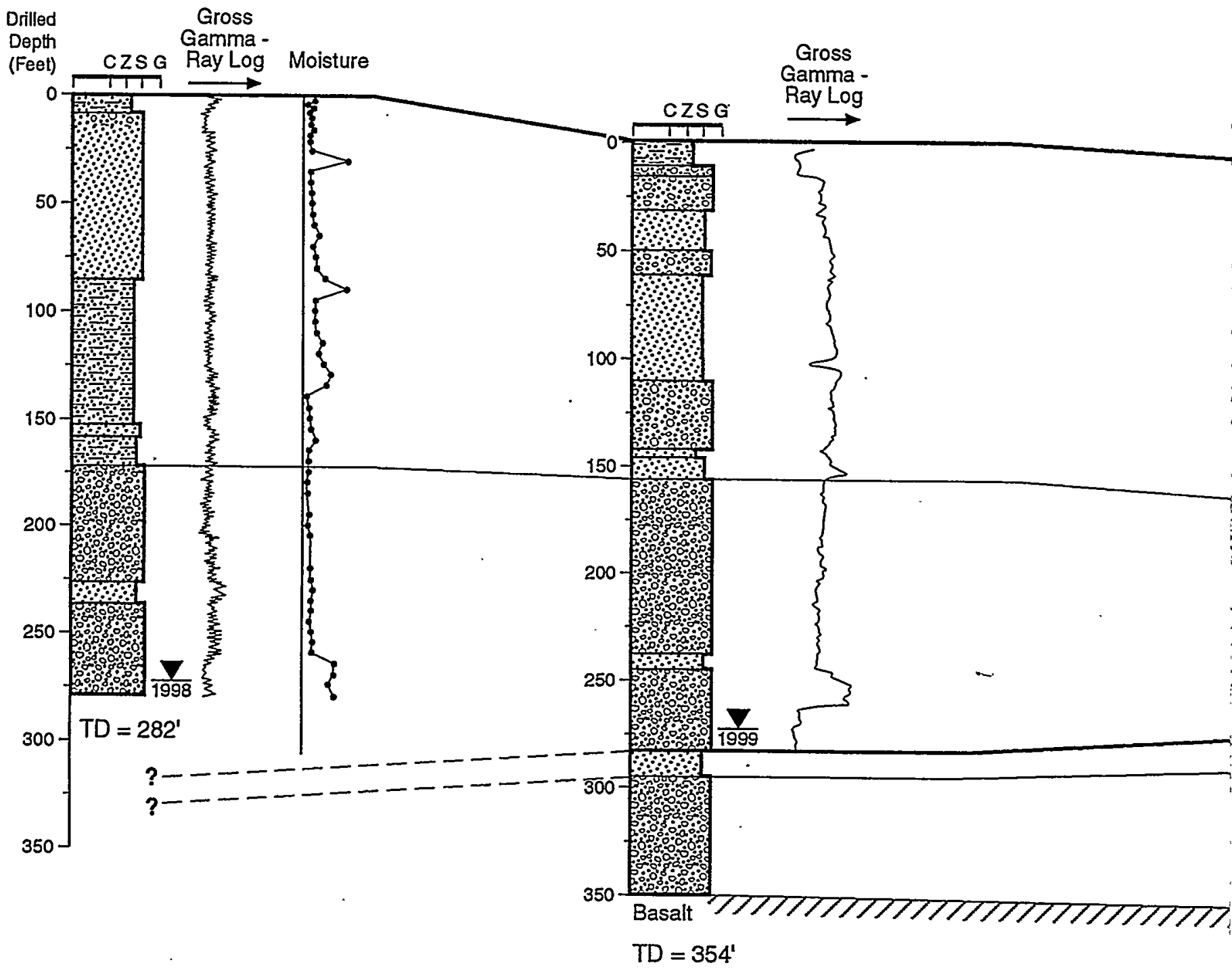

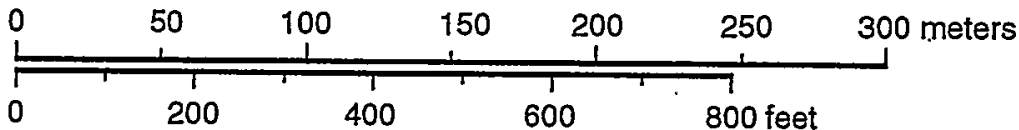

Figure 4.4. (c 


\section{A" \\ Northeast}

699-41-42

El. $640^{\prime}$

Elevation

Feet Meters

Hanford formation

Sand Sequence

Hanford formation

Gravel Sequence

ingold Fine-Grained Sequence

Ringold Formation Unit A

td)

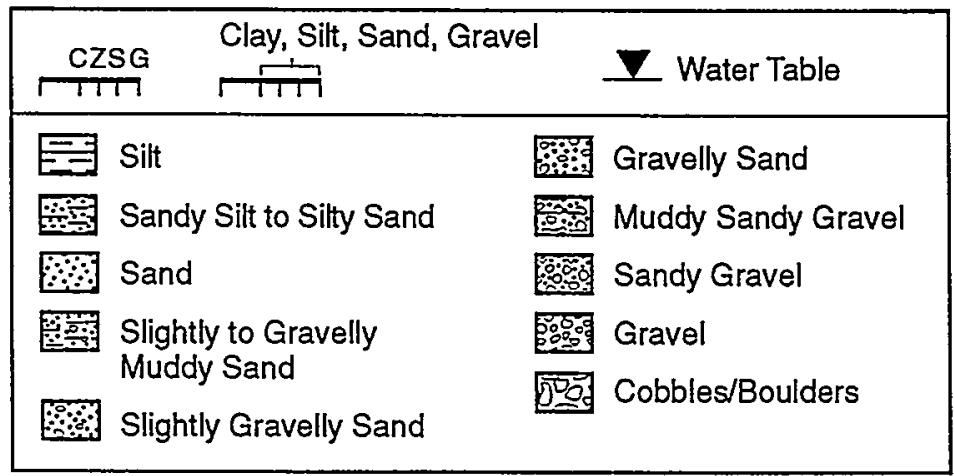




\section{B \\ West}

299-E25-33

El. $672^{\prime}$

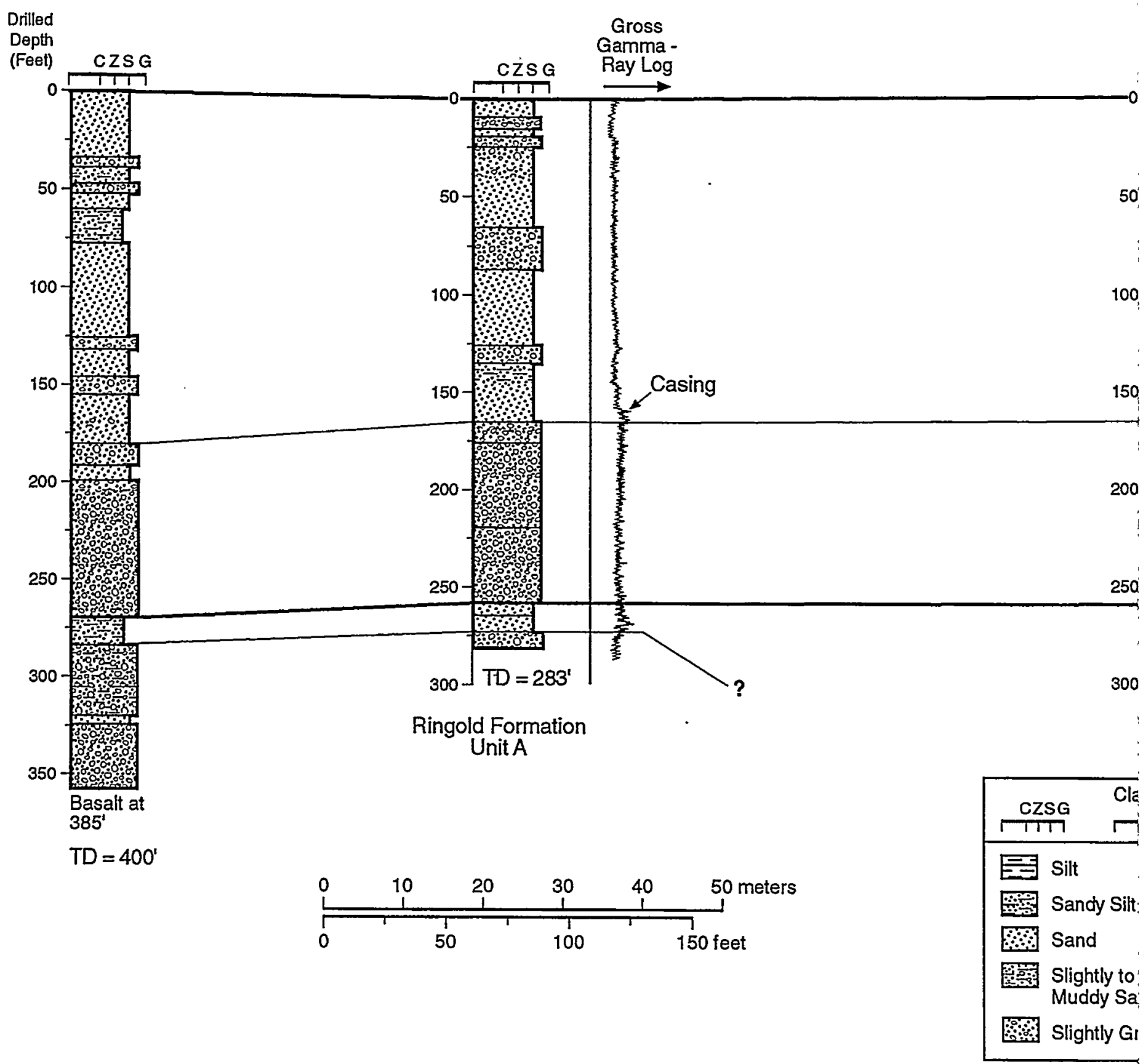

299-E25-38

El. $671^{2}$
29 


\section{B' \\ East}

$-E 25-44$

El. $673^{\prime}$
299-E25-27

El. $674^{\prime}$

299-E25-45

El. $676^{2}$

Gross

Gamma -

Gross

Gross

Gamma -

Ray Log

CZS

$\frac{11}{910}$

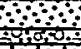

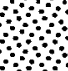

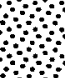

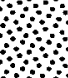

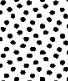

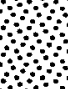

6

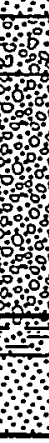

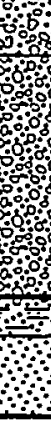

TD $=293^{\prime}$

$\longrightarrow$

CZSG

Ray Log
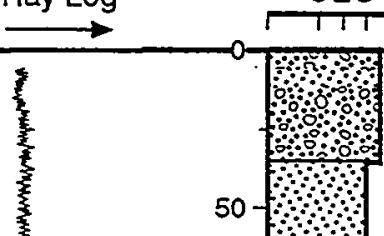

Sil

7

Water Table

Gravelly Sand

Silty Sand

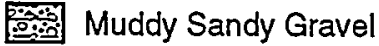

Fandy Gravel

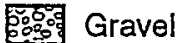

0obbles/Boulders

Elevation

Feet Meters

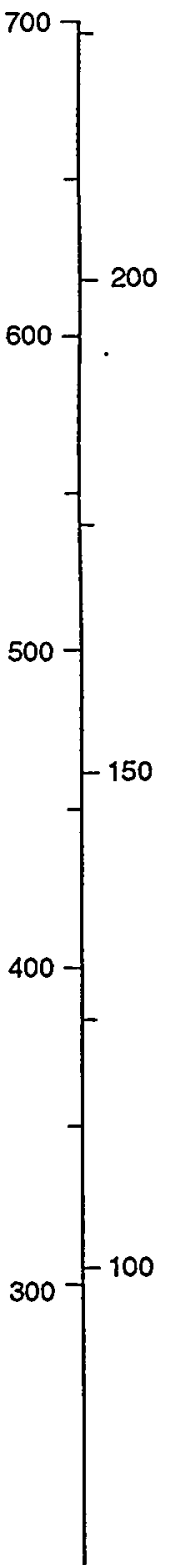

G99060223.9A

outhern Part of the Existing Disposal Site 


\section{$B^{\prime}$ \\ West}

299-E25-45

El. $676^{\prime}$
299-E25-49

El. 675'

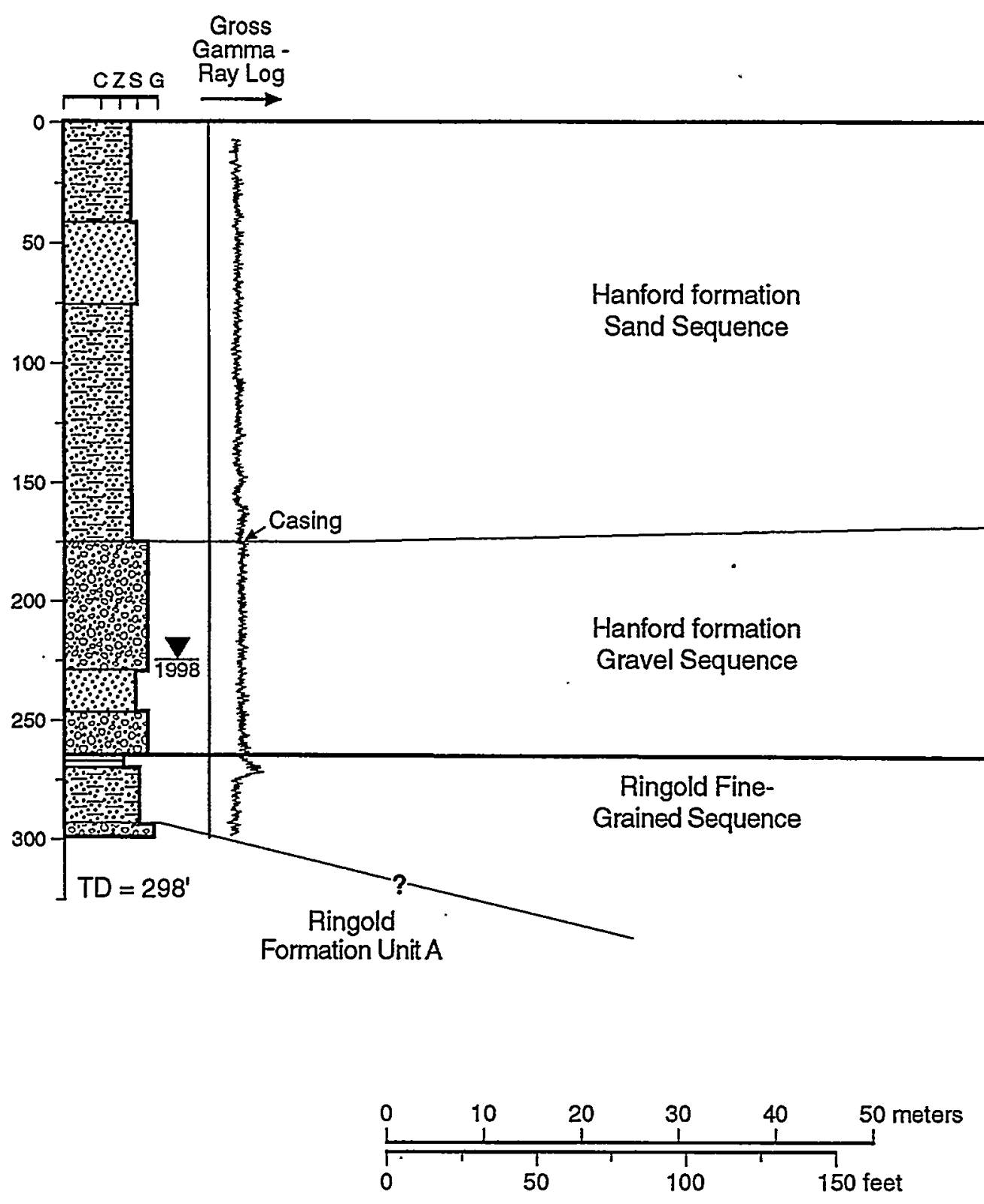

Figure 4.5. 


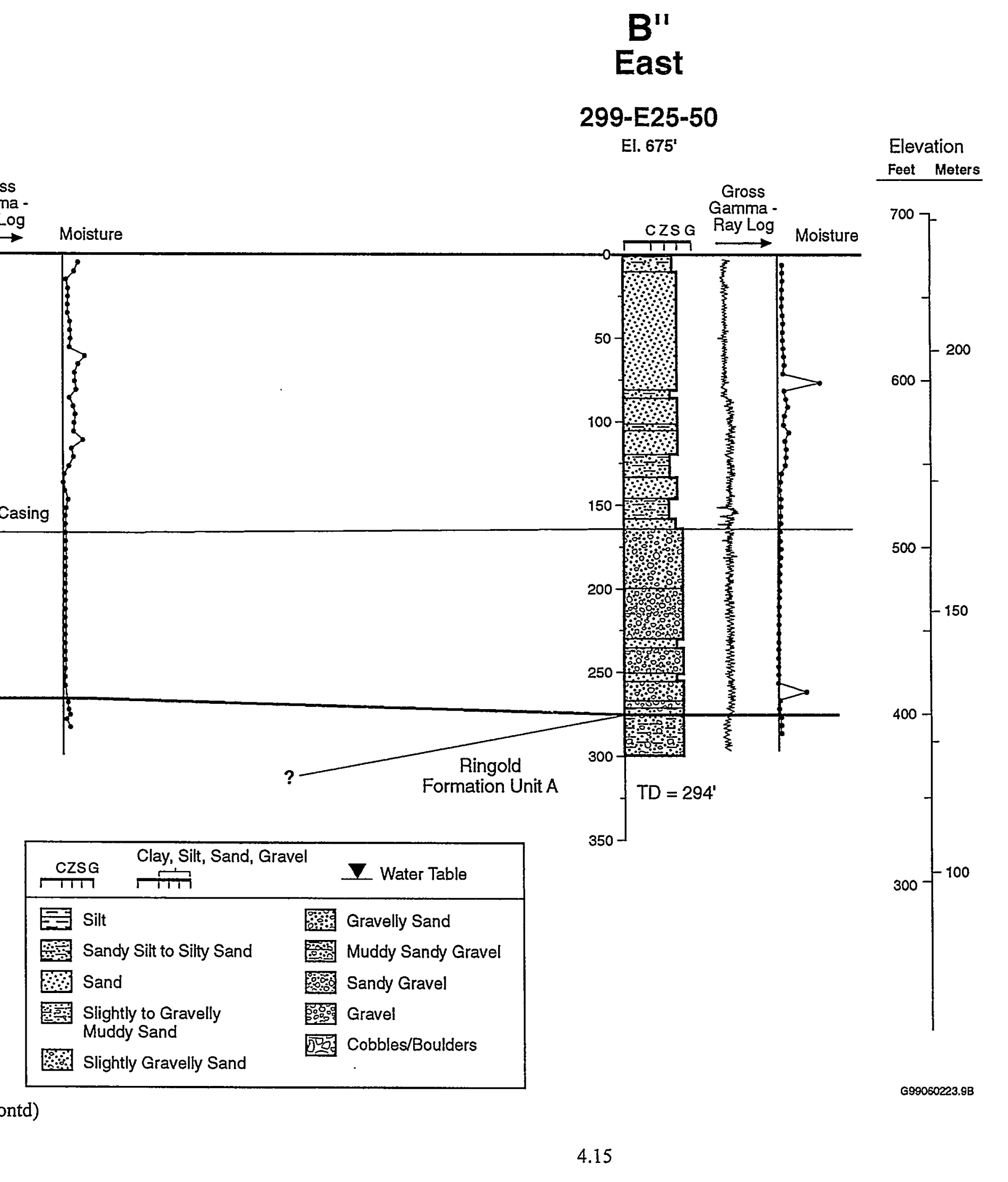




\section{C South}

299-E25-26
E1. $669^{\prime}$

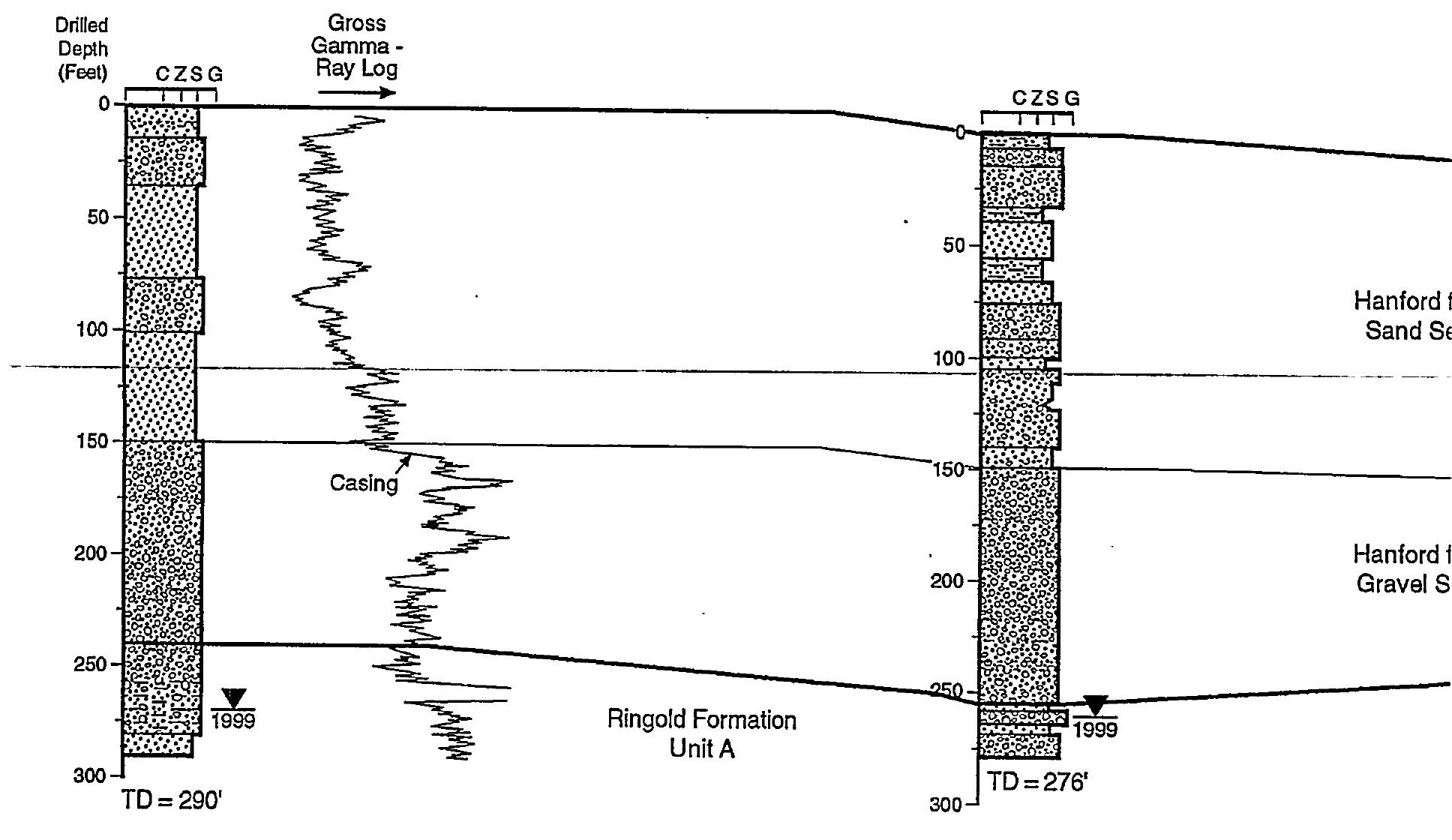

\section{9-E25-34}

\author{
EI. $661^{\prime}$
}




\section{$C^{\prime}$ \\ North}

299-E25-43

El. $647^{\prime}$
299-E26-12

El. 627'
Elevation

Feet Meters

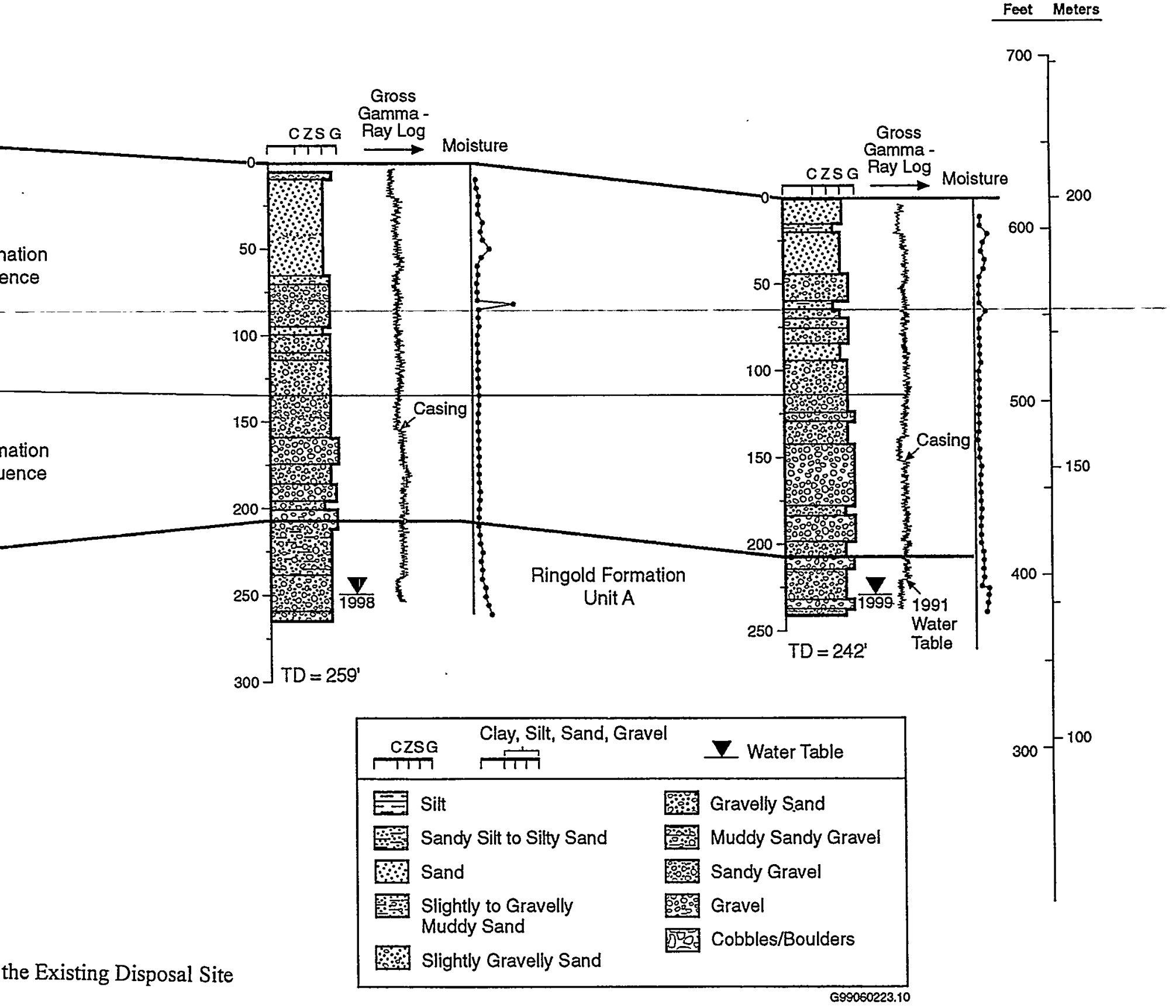




\section{D \\ West}

\section{9-E25-48}

El. $680^{\circ}$

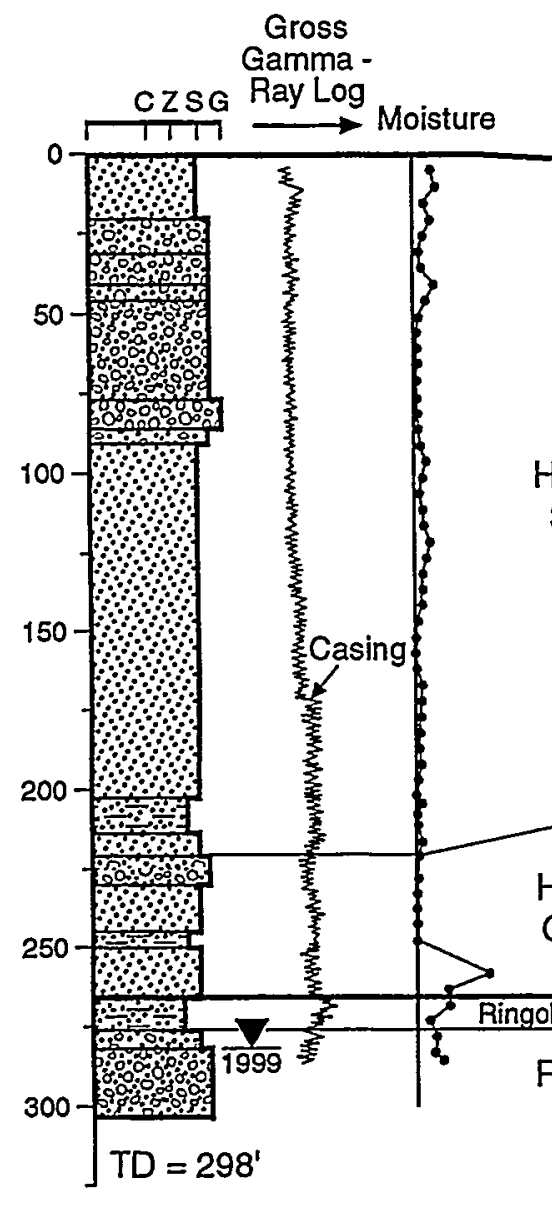

299-E25-35

El. $671^{\prime}$

Gamma -

Ray Log 
Table 4.1. Existing ILAW Disposal Site Borehole Database

\begin{tabular}{|c|c|c|c|c|c|c|c|c|c|c|c|c|c|}
\hline Borehole \# & $\begin{array}{l}\text { Ground } \\
\text { Surface } \\
\text { Elevation } \\
\text { (ft) (brass } \\
\text { plate) }\end{array}$ & $\begin{array}{c}\text { Total } \\
\text { Depth (ft) }\end{array}$ & $\begin{array}{l}\text { Elevation of } \\
\text { Top of } \\
\text { Hanford } \\
\text { Formation } \\
\text { Sand } \\
\text { Sequence } \\
\text { (ft) } \\
\end{array}$ & \begin{tabular}{|l|} 
Thickness of \\
Hanford \\
Formation \\
Sand \\
Sequence \\
(ft)
\end{tabular} & $\begin{array}{c}\text { Elevation } \\
\text { of Top of } \\
\text { Hanford } \\
\text { Formation } \\
\text { Gravel } \\
\text { Sequence } \\
\text { (ft) }\end{array}$ & $\begin{array}{l}\text { Thickness } \\
\text { of Hanford } \\
\text { Formation } \\
\text { Gravel } \\
\text { Sequence } \\
\text { (fi) }\end{array}$ & \begin{tabular}{|c|} 
Elevation of \\
Top of \\
Ringold \\
Formation \\
Fine-grained \\
Sequence \\
(ft) \\
\end{tabular} & \begin{tabular}{|} 
Thickness of \\
Ringold \\
Formation \\
Fine-grained \\
Sequence \\
(f)
\end{tabular} & $\begin{array}{c}\text { Elevation of } \\
\text { Top of } \\
\text { Ringold } \\
\text { Formation } \\
\text { Unit A } \\
\text { Gravel } \\
\text { Sequence }\end{array}$ & $\begin{array}{c}\text { Thickness } \\
\text { of Ringold } \\
\text { Formation } \\
\text { Unit A } \\
\text { Gravel } \\
\text { Sequence } \\
\text { (ft) } \\
\end{array}$ & $\begin{array}{l}\text { Elevation } \\
\text { of Top of } \\
\text { Basalt (ft) }\end{array}$ & $\begin{array}{l}\text { Depth to the } \\
\text { Water Table } \\
\text { (ft) }\end{array}$ & $\begin{array}{c}\text { Date of Water } \\
\text { Level } \\
\text { Measurement }\end{array}$ \\
\hline 299-E16-1 & 694.3 & 510 & 694 & & & & & & & & 222 & 292.37 & 1999 \\
\hline 299-E25-1 & 690.21 & 322 & 655 & 250 & NP? & & 420 & 15 & 405 & TD & & 288.52 & Jul-93 \\
\hline 299-E25-2 & 673.6 & 375 & 639 & 170 & 469 & 55 & 414 & 15 & 399 & 90 & 309 & 275.99 & Mar-99 \\
\hline 299-E25-22 & 671.66 & 295 & 672 & 196 & 476 & 58 & 418 & 20 & 398 & TD & & 273.42 & 1996 \\
\hline 299-E25-25 & $672 ?$ & 288 & 672 & 168 & 504 & 82 & $\mathrm{NP}$ & & 422 & TD & & 269.64 & Jul-98 \\
\hline 299-E25-26 & 668.51 & 290 & 668 & 150 & 518 & 105 & 413 & TD & & & & 269.7 & Mar-99 \\
\hline 299-E25-27 & 674.06 & 300 & 674 & 165 & 509 & 95 & 414 & TD & & & & 273.64 & Jun-93 \\
\hline 299-E25-28 & 660.34 & 348 & 660 & 145 & 515 & 99 & $\mathrm{NP}$ & & 416 & 97 & 319 & 263.34 & Mar-99 \\
\hline 299-E25-29 & 672.07 & 336 & 672 & 203 & 469 & 99 & 370 & 23 & 347 & TD & & 272.02 & Aug-97 \\
\hline 299-E25-30 & 677.24 & 330 & 677 & 149 & 518 & 105 & 413 & 46 & 367 & TD & & 276.8 & Jul-96 \\
\hline 299-E25-31 & 671.66 & 298 & 672 & 180 & 492 & 79 & & & 413 & TD & & 275.01 & Mar-99 \\
\hline 299-E25-32 & \begin{tabular}{|l|}
668.07 \\
\end{tabular} & 354 & 668 & 155 & 513 & 130 & 383 & 10 & 373 & 55 & 318 & 271.1 & Mar-99 \\
\hline 299-E25-33 & 672 & 400 & 672 & 205 & 492 & 90 & 402 & 15 & 387 & 100 & 287 & 268.64 & Jun-96 \\
\hline 299-E25-34 & 660.62 & 276 & 660 & 150 & 510 & 105 & 405 & 15 & 390 & TD & & 263.94 & Mar-99 \\
\hline $299-\mathrm{E} 25-35$ & 670.89 & 285 & 671 & $175^{\circ}$ & 496 & 85 & 411 & 10 & 401 & TD & & 274.97 & Mar-99 \\
\hline 299-E25-37 & 670.29 & 280 & 670 & 165 & 505 & 105 & & & 400 & $\mathrm{TD}$ & & 272.3 & Oct-95 \\
\hline 299-E25-38 & 670.54 & 283 & 670 & 165 & 505 & 92 & 413 & 13 & 400 & TD & & 271.52 & Oct-93 \\
\hline 299-E25-39 & 668.45 & 282 & 668 & 175 & 493 & 55 & 438 & 10 & 428 & TD & & 271.07 & Jul-98 \\
\hline 299-E25-40 & 662.8 & 274 & 663 & 195 & 468 & 60 & 408 & 10 & 398 & TD & & 266.37 & Jun-05 \\
\hline 299-E25-41 & 668.1 & 279 & 668 & 220 & 468 & 55 & 413 & 15 & 398 & TD & & 271.82 & Jun-05 \\
\hline 299-E25-42 & 679.71 & 295 & 680 & 220 & 460 & TD & & & & & & 283.78 & Mar-99 \\
\hline 299-E25-43 & 646.52 & 260 & 646 & 134 & 511 & 75 & $\mathrm{NP}$ & & 436 & TD & & 249.87 & Jul-98 \\
\hline 299-E25-44 & 672.9 & 293 & 673 & 165 & 508 & 98 & 410 & TD & & & & 275.62 & Mar-99 \\
\hline 299-E25-45 & 675.74 & 297 & 676 & 175 & 501 & 94 & 407 & 26 & 381 & TD & & 277.93 & Apr-98 \\
\hline 299-E25-48 & 679.68 & 298 & 680 & 220 & 460 & 46 & 414 & 18 & 396 & TD & & 282.64 & Mar-99 \\
\hline 299-E25-49 & 675.44 & 293 & 675 & 165 & 510 & 100 & 410 & TD & & & & & \\
\hline 299-E25-50 & 675.32 & 294 & 675 & 165 & 510 & 110 & 400 & TD & & & & & - \\
\hline
\end{tabular}


Table 4.1. (contd)

\begin{tabular}{|c|c|c|c|c|c|c|c|c|c|c|c|c|c|}
\hline Borehole \# & $\begin{array}{c}\text { Ground } \\
\text { Surface } \\
\text { Elevation } \\
\text { (ft) (brass } \\
\text { plate) }\end{array}$ & $\begin{array}{c}\text { Total } \\
\text { Depth (ft) }\end{array}$ & $\begin{array}{l}\text { Elevation of } \\
\text { Top of } \\
\text { Hanford } \\
\text { Formation } \\
\text { Sand } \\
\text { Sequence } \\
\text { (ft) }\end{array}$ & $\begin{array}{l}\text { Thickness of } \\
\text { Hanford } \\
\text { Formation } \\
\text { Sand } \\
\text { Sequence } \\
\text { (ft) }\end{array}$ & $\begin{array}{c}\text { Elevation } \\
\text { of Top of } \\
\text { Hanford } \\
\text { Formation } \\
\text { Gravel } \\
\text { Sequence } \\
\text { (ft) }\end{array}$ & $\begin{array}{l}\text { Thickness } \\
\text { of Hanford } \\
\text { Formation } \\
\text { Gravel } \\
\text { Sequence } \\
\text { (ft) }\end{array}$ & $\begin{array}{c}\text { Elevation of } \\
\text { Top of } \\
\text { Ringold } \\
\text { Formation } \\
\text { Fine-grained } \\
\text { Sequence } \\
\text { (ft) }\end{array}$ & \begin{tabular}{|} 
Thickness of \\
Ringold \\
Formation \\
Fine-grained \\
Sequence \\
(ft)
\end{tabular} & $\begin{array}{c}\text { Elevation of } \\
\text { Top of } \\
\text { Ringold } \\
\text { Formation } \\
\text { Unit A } \\
\text { Gravel } \\
\text { Sequence }\end{array}$ & \begin{tabular}{|} 
Thickness \\
of Ringold \\
Formation \\
Unit A \\
Gravel \\
Sequence \\
(ft)
\end{tabular} & $\begin{array}{l}\text { Elevation } \\
\text { of Top of } \\
\text { Basalt ( } \mathrm{ft})\end{array}$ & $\begin{array}{l}\text { Depth to the } \\
\text { Water Table } \\
\text { (ft) }\end{array}$ & $\begin{array}{l}\text { Date of Water } \\
\text { Level } \\
\text { Measurement }\end{array}$ \\
\hline 299-E25-234 & 622 & 141 & 622 & 125 & 497 & TD & & & & & & & \\
\hline 299-E25-1000 & 670.96 & 392 & 671 & 180 & 481 & 111 & 370 & 10 & 360 & 67 & 293 & 274.15 & Jun-98 \\
\hline 299-E26-12 & 627.27 & 242 & 627 & 115 & 512 & 95 & NP & & 417 & TD & & 231.01 & Mar-99 \\
\hline $699-41-42$ & 640.32 & 345 & 634 & 150 & 485 & 73 & 412 & 27 & 385 & 80 & 305 & 240.87 & Mar-99 \\
\hline $699-42-42 B$ & 579.83 & 250 & 580 & 109 & 471 & 50 & 421 & 23 & 398 & TD & & 179.64 & 1999 \\
\hline $699-43-43 \mathrm{~K}$ & 579.03 & 263 & 579 & 109 & 470 & 49 & 421 & 23 & 398 & 62 & 336 & & \\
\hline Average & & & & 169.16 & & 84.66 & & 18.11 & & 78.71 & & & \\
\hline Std Dev & & & & 33.21 & & 22.72 & & 8.81 & & 17.77 & & & \\
\hline \multicolumn{14}{|c|}{$\begin{array}{l}\text { Elevations are feet above sea level. } \\
\mathrm{NP}=\text { Not present. } \\
\mathrm{TD}=\text { Total depth of borehole. }\end{array}$} \\
\hline
\end{tabular}




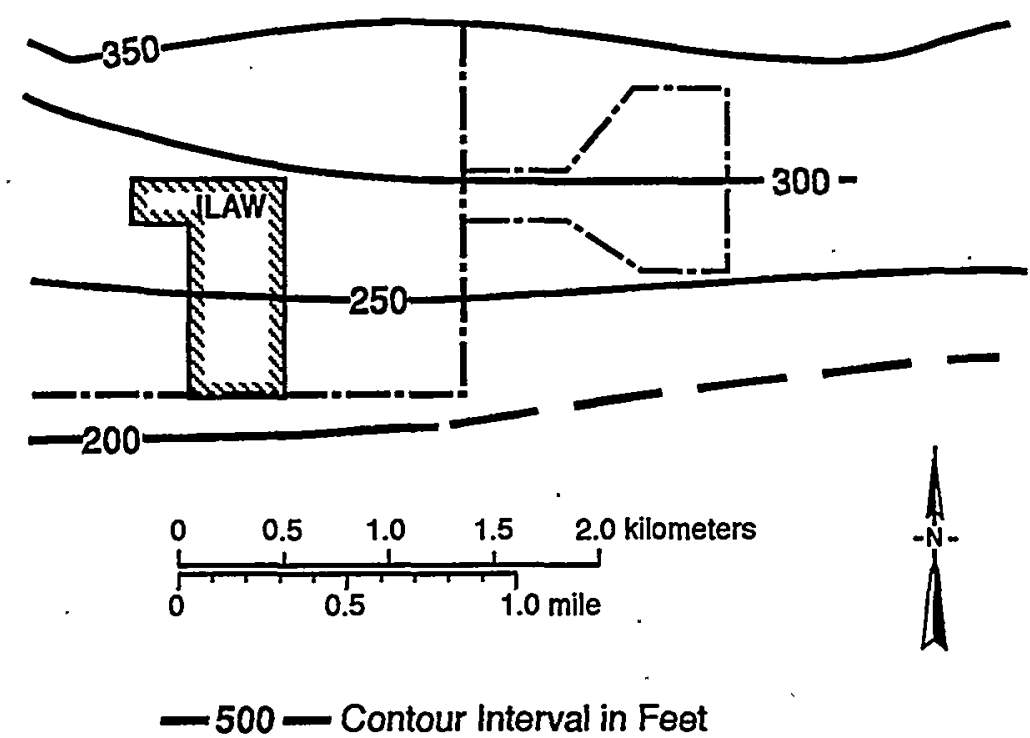

G99110106.9

Figure 4.8. Generalized Elevation of the Top of the Columbia River Basalt Group Under the 200-East Area

Figure 4.9 is a structure contour map of the top of the Ringold Formation. The map shows a roughly northwest to southeast trending low across the center of the existing disposal site with about $66 \mathrm{ft}(20 \mathrm{~m})$ of relief in the area. The structural low may be due to post-depositional scouring by Pleistocene floods.

\subsubsection{Hanford Formation Gravel Sequence}

A thick sequence of Pleistocene Hanford formation flood gravels overlies the Ringold Formation. This sequence is equivalent, at least in part, to the lower gravel sequence of the Hanford formation of Lindberg et al. (1993) and Lindsey et al. (1992), to the Hanford formation H3 sequence of Lindsey et al. (1994a), and to the Qfg deposits of Reidel and Fecht (1994a, 1994b) (Figure 4.2).

The Hanford formation gravel sequence is described on borehole logs of cuttings and samples as dominantly sandy gravel and gravelly sand in the existing disposal site. Thin beds of sand, generally less than about $10 \mathrm{ft}(3 \mathrm{~m})$ in thickness, are common but not abundant. Silt lenses were not noted on the borehole logs of the gravel sequence at the existing disposal site. The gravels are generally poorly sorted, subrounded to subangular and have basalt content up to $80 \%$. Calcium carbonate is common but the gravel sequence is not cemented.

Based on observation of outcrop and intact core, the gravel sequence sediments described on the borehole logs are interpreted to be gravel-dominated facies. This facies is typically open framework or matrix supported framework, granule to boulder gravel with massive bedding, plane to low-angle bedding, and cross-bedding. Lenticular and discontinuous units of sand-dominated facies are interbedded with gravel-dominated facies. The Hanford formation gravel sequence was deposited by high-energy; cataclysmic, Pleistocene floods. 


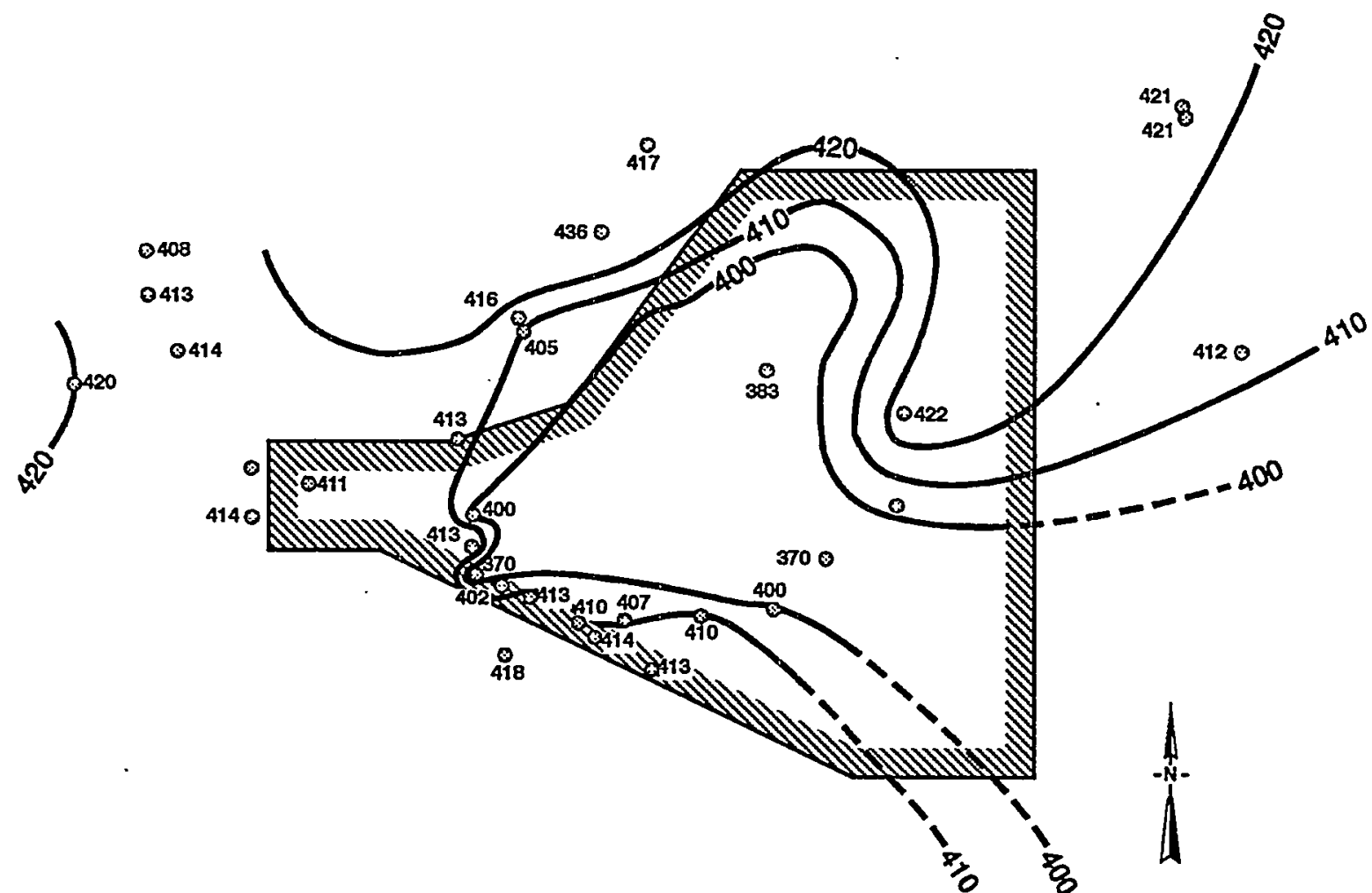

0

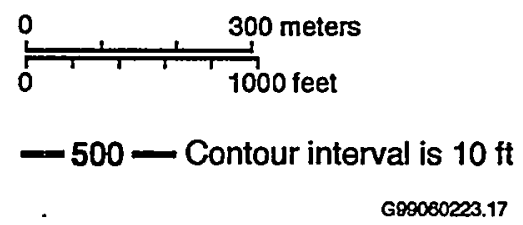

Figure 4.9. Structure Contour Map of the Top of the Ringold Formation in the Existing Disposal Site. Values are Elevations Above Sea Level.

The base of the Hanford formation gravel sequence was picked at the top of the silt, silty sand, or sand defining the top of the Ringold fine-grained sequence. In boreholes where the Ringold fine-grained sequence does not occur, the contact was chosen at a change in the degree of induration and/or change in the basalt content of the gravel. The lithology change was generally fairly dramatic going from about $50 \%$ or more basalt in the Hanford formation gravel sequence to about 10 to $15 \%$ basalt in the underlying Ringold Formation. In a few boreholes where neither the Ringold fine-grained sequence nor a dramatic change in lithology was evident, the base of the Hanford formation gravel sequence was taken from data in Lindberg et al. (1993).

Figure 4.10 shows a structure contour map on the top surface of the Hanford formation gravel sequence. The map shows that the top of the sequence has about $55 \mathrm{ft}(17 \mathrm{~m})$ of relief in the existing disposal site area and is highest through the center of the area in a north to north-northwest trend. 


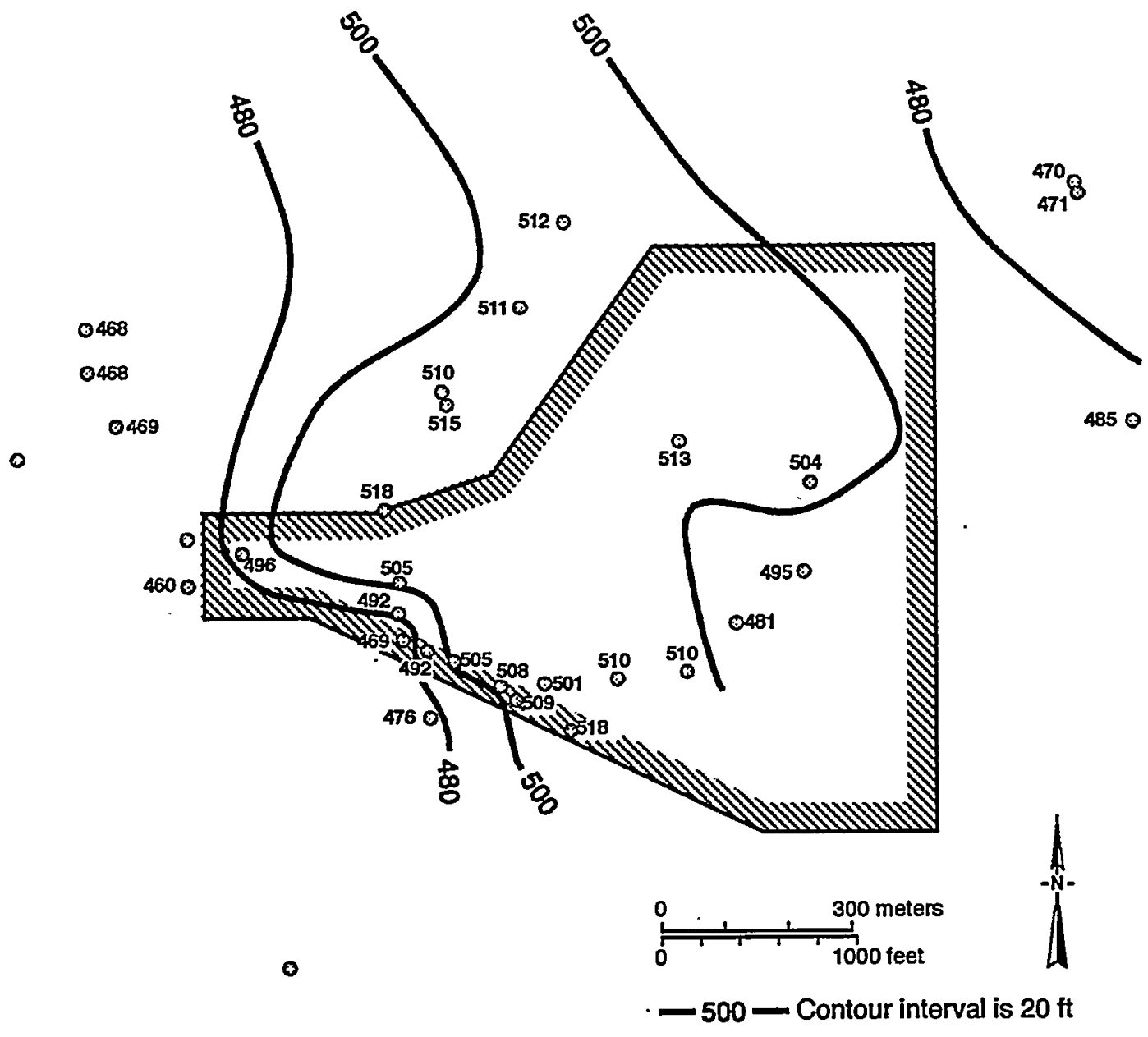

G99060223.15

Figure 4.10. Structure Contour Map of the Top of the Hanford Formation Gravel Sequence in the Existing Disposal Site. Values are elevations in feet.

\subsubsection{Hanford Formation Sand Sequence}

The Hanford formation sand sequence overlies the Hanford formation gravel sequence. This sequence is equivalent to the sandy sequence of the Hanford formation of Lindberg et al. (1993) and Lindsey et al. (1992), the Hanford formation H2 sequence of Lindsey et al. (1994a), and to Qfs of Reidel and Fecht (1994a, 1994b) (Figure 4.2).

The Hanford formation sand sequence is described on borehole logs of cuttings as coarse to very fine sand. Beds of silty sand and gravelly sand are common; sandy gravels also exist but are less common. The composition of the sand sequence varies from typically 50 to $70 \%$ mafic and 30 to $50 \%$ felsic. Minor calcium carbonate is common in the sand sequence as indicated on the geologist's logs. Also, some caliche layers were noted on geologist's logs. The caliche is generally fine to medium pebble-sized cemented clasts. 
The sand-sequence sediments are interpreted to consist of typical sand-dominated facies intercalated with beds of the silt-dominated and gravel-dominated facies. The amount of gravel-dominated facies sediment tends to increase toward the northwestern and western parts of the existing disposal site (see Figures 4.4 through 4.7 ) whereas the sequence is mostly sand-dominated with some silt-dominated beds in the central and eastern parts of the site.

Beds of silt-dominated facies were noted in the Hanford formation sand sequence from many geologist's logs. The beds are generally 6 in. $(0.15 \mathrm{~m})$ or less in thickness and in many boreholes were moist to wet relative to adjacent sediment. Silt-dominated units primarily were noted in three depth intervals: 10 to $15 \mathrm{ft}$ ( 3 to $4.5 \mathrm{~m}$ ), 20 to about $35 \mathrm{ft}$ ( 6 to about $11 \mathrm{~m}$ ), and 100 to $135 \mathrm{ft}$ ( 30 to $41 \mathrm{~m}$ ). However, many silt-dominated units were identified outside these depth intervals between 50 and $70 \mathrm{ft}$ (15 and $21 \mathrm{~m}$ ) and between 87 and $97 \mathrm{ft}(26.5$ and $29.5 \mathrm{~m})$. Silt intervals were commonly noted as layered or bedded (with sand) by the geologist. In some boreholes, anomalies in gross gamma-ray logs and moisture content data reflect the presence of silt-dominated strata. In other boreholes, similar anomalies probably reflect silt-dominated strata that were not noted on the lithologic logs. Silt-dominated units cannot be correlated among boreholes and are interpreted to be lenticular. However, samples are normally collected every $5 \mathrm{ft}(1.5 \mathrm{~m})$ during drilling so most thin silt-dominated units would not get described.

The geologist's logs for two boreholes (299-E25-26 and 299-E25-220) indicate the presence of Mt. St. Helens set "S" ash at 14 to $15 \mathrm{ft}$ ( 4.3 to $4.6 \mathrm{~m}$ ) depth. If this horizon is Mt. St. Helens set "S" ash, it indicates an age of 13,000 years for the sediment at this depth.

The Hanford formation sand sequence in the existing disposal site varies from 134 to $220 \mathrm{ft}$ (41 to $67 \mathrm{~m}$ ) in thickness with an average thickness of $169 \mathrm{ft}(51 \mathrm{~m})$. Because of the difficulty in picking a contact between the Hanford formation sand sequence and the overlying surficial sands, both are included in the sand sequence thickness given in Table 4.1 .

The bottom of the Hanford formation sand sequence was chosen as the top of the first, thick $(>10 \mathrm{ft}$ [3 m]), sandy gravel or gravelly sand underlying at least $25 \mathrm{ft}(7.6 \mathrm{~m})$ of sand, silty sand or slightly gravelly sand. Although there are some differences, this change in lithology agrees well with that used by Lindberg et al. (1993), who used the data set from Lindsey et al. (1992), to delineate the Hanford formation sand sequence from the underlying gravel sequence.

\subsubsection{Recent Surface Deposits}

Ground penetrating surveys conducted in 1998 found a variably thick sequence of surficial deposits across most of the existing disposal site. These deposits consist of Holocene wind blown sand and are typically about $10 \mathrm{ft}(3 \mathrm{~m})$ thick. Some geologist's logs and driller's logs note a surficial deposit but most do not. In some boreholes, the thickness of the surfical deposits can be established based on lithology where the eolian sands overly sandy gravel or gravelly sand. In those boreholes, the eolian deposits are between about 5 and $15 \mathrm{ft}(1.5$ and $4.5 \mathrm{~m})$ in thickness. In other boreholes, the surfical sands overly the 
Hanford formation sand sequence. The texture of the Hanford formation sand sequence is similar to the eolian material making it hard to differentiate the two without being able to observe the structures (laminations).

\subsection{New ILAW Disposal Site}

\subsubsection{Previous Studies}

The new ILAW disposal site is an area where no previous construction or disposal sites exist so no major geologic studies have been carried out there. Studies relevant to the site are summarized in Tallman et al. (1979), DOE (1988), Lindsey et al. (1993, 1994a, 1994b), Lindsey (1996), Reidel and Reynolds (1998), and Reidel et al. (1998). Less data are available for the new ILAW site and it is generally of poorer quality compared to data from the existing disposal site. The first major activity was the drilling of borehole 299-E17-21 in 1998 at the southwest end of the site and obtaining the first highquality data from the area.

\subsubsection{Site Stratigraphy}

The stratigraphy at the new ILAW disposal site consists of the Hanford formation and Ringold Formation overlying the Columbia River Basalt Group. Surfacial sediments are mainly eolian deposits consisting of reworked Hanford sands and silts.

The stratigraphy and the stratigraphic model developed for this study is summarized in Figures 4.2 and 4.11. This diagram is based upon more detailed cross-sections (Figures 4.12 through 4.16).

The stratigraphy of the new ILAW disposal site is divided from youngest to oldest into the following units:

- Eoliañ Deposits

- Hanford formation, sandy unit (H2 of Lindsey et al. 1994b)

- Layer 3 (extends into upper gravelly unit)

- Layer 2

- Layer 1

- Hanford formation, basal gravel units (H3 of Lindsey et al. 1994b)

- Ringold Formation

- Unit E

- Lower Mud

- Unit A

- Columbia River Basalt Group.

Sequences of sandy gravels to gravelly sands $(\mathrm{G} 1, \mathrm{G} 2, \mathrm{G} 3, \mathrm{G} 4)$ and sand to silty sand units (S, S1, S2, S3) can be recognized in the Hanford formation layers (Table 4.2) but correlation across the area is 


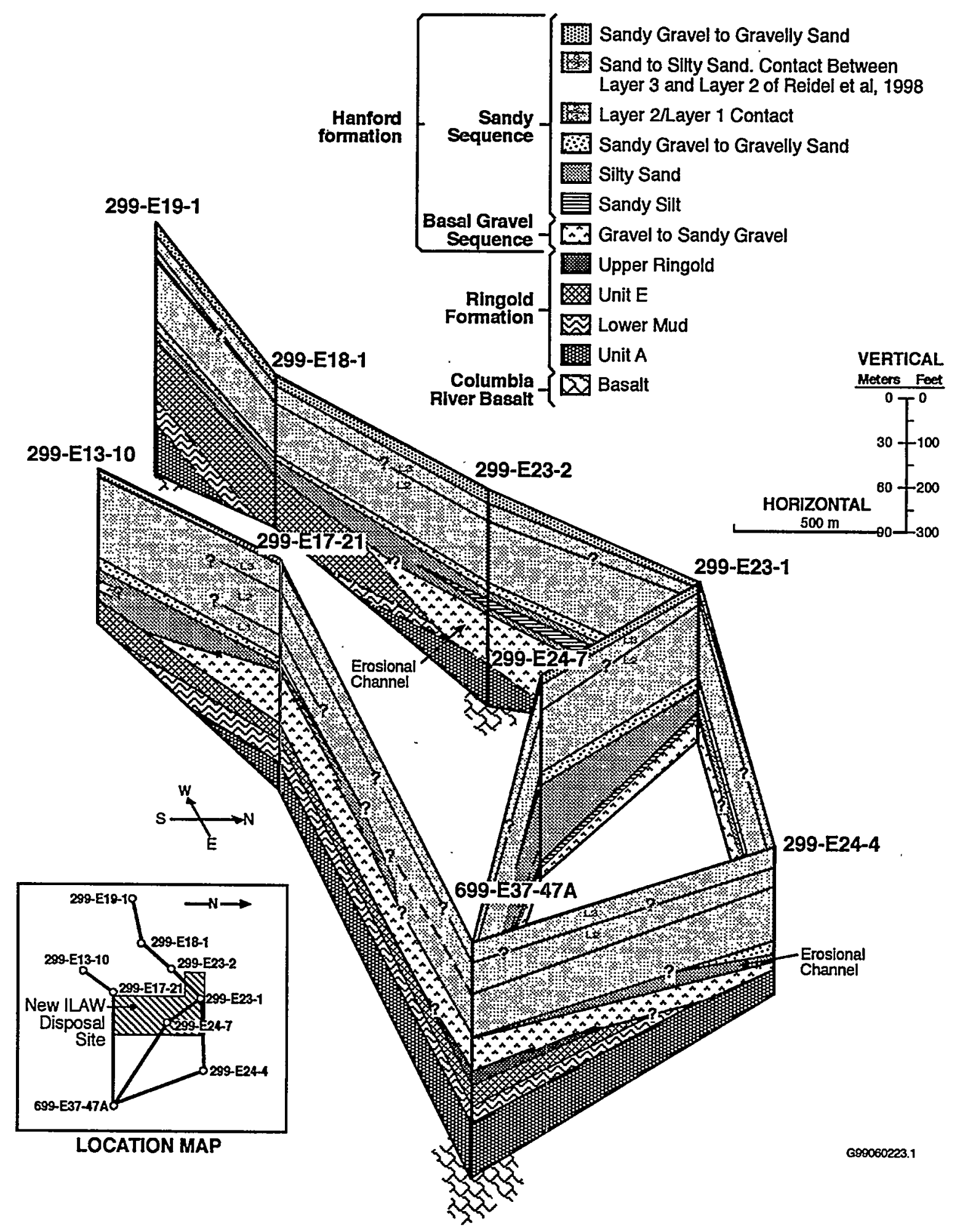

Figure 4.11. Fence Diagram of the New ILAW Disposal Site and Vicinity 
Table 4.2. Stratigraphic Information from Boreholes in and Adjacent to the New ILAW Disposal Site

\begin{tabular}{|c|c|c|c|c|c|c|c|c|c|c|c|c|c|c|c|c|c|c|c|c|c|c|c|}
\hline Borehole & $\begin{array}{c}\text { Back- } \\
\text { fill }\end{array}$ & $\mid \begin{array}{c}\text { Surface } \\
\text { Sand } \\
(\mathbf{S})\end{array}$ & \begin{tabular}{|l} 
Top of \\
Layer \\
$3($ L3)
\end{tabular} & \begin{tabular}{|l} 
Top of \\
Layer \\
$2(22)$ \\
\end{tabular} & $\begin{array}{l}\text { Top of } \\
\text { Layer } \\
1(\mathrm{~L} 1) \\
\end{array}$ & \begin{tabular}{|c|} 
Top of \\
Sandy \\
Gavavil \\
(G1) \\
\end{tabular} & \begin{tabular}{|c} 
Surface \\
Elevation \\
[brass cap \\
or casing \\
(C)]
\end{tabular} & $\begin{array}{c}\text { Top of } \\
\text { Sand 1 } \\
\text { (S1) } \\
\end{array}$ & \begin{tabular}{|c|} 
Top of \\
Sandy \\
Gravel 2 \\
(G2) \\
\end{tabular} & \begin{tabular}{|c|} 
Top of \\
Sand to \\
Silty \\
Gavelly \\
Sand 2 \\
(S2) \\
\end{tabular} & \begin{tabular}{|l|} 
\\
Top of \\
Gravel \\
3 (G3) \\
\end{tabular} & $\begin{array}{c}\text { Top of } \\
\text { Sand to } \\
\text { Silty } \\
\text { Sand } 3 \\
\text { (S3) } \\
\end{array}$ & $\begin{array}{l}\text { Top of } \\
\text { Gravel } \\
4(\mathrm{G} 4) \\
\end{array}$ & $\begin{array}{c}\text { Thickness } \\
\text { of } \\
\text { Hanford } \\
\text { Forma- } \\
\text { tion }\end{array}$ & \begin{tabular}{|c|} 
Top of \\
Ringold
\end{tabular} & $\begin{array}{l}\text { Top of } \\
\text { Unit E } \\
\end{array}$ & Silt & \begin{tabular}{|c} 
Top of \\
Lower \\
Mud
\end{tabular} & $\begin{array}{l}\text { Thickness } \\
\text { of Ringold }\end{array}$ & \begin{tabular}{|l|} 
Top of \\
Unit A
\end{tabular} & Basalt & \begin{tabular}{|c|} 
Water \\
Table \\
Eleva- \\
tion \\
\end{tabular} & $\begin{array}{c}\text { Date of Water } \\
\text { Level } \\
\text { Measurement }\end{array}$ \\
\hline E13-10 & $\mathbf{N}$ & 733 & ND & ND & ND & NP & 733 (C) & 733 & 713 & 705 & 537 & 514 & 494 & 239 & 449 & 494 & NP & $\mathbf{N P}$ & ND & NP & NP & 399.74 & Mar-99 \\
\hline E17-12 & $\bar{N}$ & 719 & 669 & 647 & 564 & 704 & $719(\mathrm{C})$ & 694 & $\mathrm{NP}$ & 694 & 497 & 479 & NP & 290 & 429 & 429 & $\mathrm{NP}$ & $\mathrm{NP}$ & ND & NP & NP & \begin{tabular}{|c|}
399.17 \\
\end{tabular} & Mar-99 \\
\hline E17-13 & 31 & NP & $\mathrm{ND}$ & 647 & ND & ND & $719(\mathrm{C})$ & 689 & NP & 689 & 494 & 469 & NP & 265 & 424 & 424 & NP & NP & ND & NP & NP & |399.56 & Mar-98 \\
\hline E17-17 & $\mathrm{N}$ & 716 & ND & 651 & ND & 716 & 717 & 702 & NP & 702 & $\mathrm{NP}$ & 546 & 492 & 299 & 417 & 492 & 442 & NP & ND & NP & NP & \begin{tabular}{|l|}
399.8 \\
\end{tabular} & Oct-98 \\
\hline E17-18 & $\mathrm{N}$ & 717 & ND & 648 & ND & 713 & 718 & 693 & 626 & 616 & $\mathrm{NP}$ & 546 & 483 & 291 & 426 & 483 & 434 & $\mathrm{NP}$ & ND & NP & NP & 399.27 & Mar-99 \\
\hline E17-20 & $\mathrm{N}$ & 716 & ND & 646 & ND & 706 & 717 & 696 & 676 & 671 & 566 & 556 & NP & ND & NP & 491 & 436 & NP & ND & $\mathrm{NP}$ & NP & 400.55 & Apr-97 \\
\hline E17-21 & $\mathrm{N}$ & 735 & 730 & 677 & & 730 & 735 & 720 & 715 & 705 & 523 & 505 & 447 & 238 & 497 & 400 & $\mathrm{NP}$ & 357 & ND & 296 & NP & 403 & Apr-98 \\
\hline E18-1 & $\mathbf{N}$ & NA & ND & ND & ND & 720 & 716 & 700 & 675 & 660 & 545 & 535 & NP & 215 & 505 & 505 & $\mathrm{NP}$ & NP & ND & NP & $\mathrm{NP}$ & 399.44 & Mar-99 \\
\hline E18-3 & $\mathbf{N}$ & 718 & ND & 656 & ND & 715 & 718 & 703 & $\mathrm{ND}$ & 656 & 546 & 542 & $\mathrm{NP}$ & 235 & 483 & 483 & NP & NP & ND & NP & $\mathrm{NP}$ & 401.1 & Jun-96 \\
\hline E18-4 & $\mathrm{N}$ & 718 & $\mathrm{ND}$ & ND. & ND & 715 & 718 & 699 & 668 & 658 & ND & 568 & $\mathrm{NP}$ & 232 & 486 & 486 & $\mathrm{NP}$ & NP & ND & $\mathrm{NP}$ & $\mathrm{NP}$ & 401.17 & Jun-96 \\
\hline E19-1 & $\mathrm{N}$ & 736 & ND & ND & ND & 735 & $736(\mathrm{C})$ & 716 & 686 & 672 & 520 & 506 & $\mathrm{NP}$ & 250 & 486 & 486 & NP & 346 & 285 & 306 & 201 & ND & $\mathrm{ND}$ \\
\hline E23-1 & $\mathrm{N}$ & 0 to 5 & ND & 665 & ND & 704 & $710(\mathrm{C})$ & NP & 689 & 665 & 489 & 477 & 454 & $\mathrm{ND}$ & NP & 454 & 417 & $\mathrm{NP}$ & ND & NP & $\mathrm{NP}$ & 399.63 & Mar-99 \\
\hline$\overline{E 23-2}$ & 0 & \begin{tabular}{|l|}
720 \\
\end{tabular} & ND & 628 & ND & $\mathrm{NP}$ & $721(\mathrm{C})$ & 720 & $\mathrm{NP}$ & 605 & 520 & 500 & 484 & 290 & 430 & 430 & ND & NP & 166 & ND & 264 & 401.59 & Dec-94 \\
\hline E24-4 & 20 & 696 & ND & 646 & ND & $\mathrm{NP}$ & $697(\mathrm{C})$ & 696 & $\mathrm{NP}$ & ND & ND & ND & 431 & 270 & 426 & 466 & ND & NP & ND & $\mathrm{NP}$ & $\mathrm{NP}$ & 399.53 & Aug-98 \\
\hline E24-7 & $\mathrm{N}$ & 0 & ND & 652 & ND & 716 & 716 (C) & 708 & $\mathrm{NP}$ & 708 & 500 & 486 & 448 & 380 & 336 & 336 & 296 & \begin{tabular}{|l|}
$\mathrm{ND}$ \\
\end{tabular} & 70 & ND & 266 & 400.52 & Jun-97 \\
\hline E24-16 & $\mathrm{N}$ & 715 & ND & 656 & ND & 714 & 715 & 706 & 626 & 616 & 526 & 496 & $\mathrm{NP}$ & ND & $\mathrm{NP}$ & 460 & 426 & NP & ND & NP & $\mathrm{NP}$ & 399.41 & Mar-99 \\
\hline E24-17 & $\mathbf{N}$ & 716 & ND & 659 & ND & 711 & 716 & 706 & $\mathrm{NP}^{\prime}$ & 706 & 536 & 524 & 491 & 295 & 421 & 421 & NP & NP & ND & $\mathrm{NP}$ & NP & 399.59 & Apr-97 \\
\hline E24-18 & $\mathrm{N}$ & 716 & ND & 664 & ND & 715 & 716 & 699 & $\mathrm{NP}$ & 699 & 506 & 481 & 456 & 325 & 391 & 391 & NP & $\mathrm{NP}$ & ND & NP & $\mathrm{NP}$ & \begin{tabular}{|l|}
399.3 \\
\end{tabular} & Mar-99 \\
\hline E37-47A & $\mathrm{N}$ & 716 & ND & ND & ND & $\mathrm{NP}$ & 715 & 716 & $\mathrm{NP}$ & 716 & 526 & $\mathrm{NP}$ & 474 & 284 & 432 & 412 & NP & 350 & 231 & 304 & 201 & 405 & Oct-96 \\
\hline $\begin{array}{l}\mathrm{N}= \\
\mathrm{ND}= \\
\mathrm{NP}=\end{array}$ & & & & & & & & & & & & & & & & & & & & & & & \\
\hline
\end{tabular}




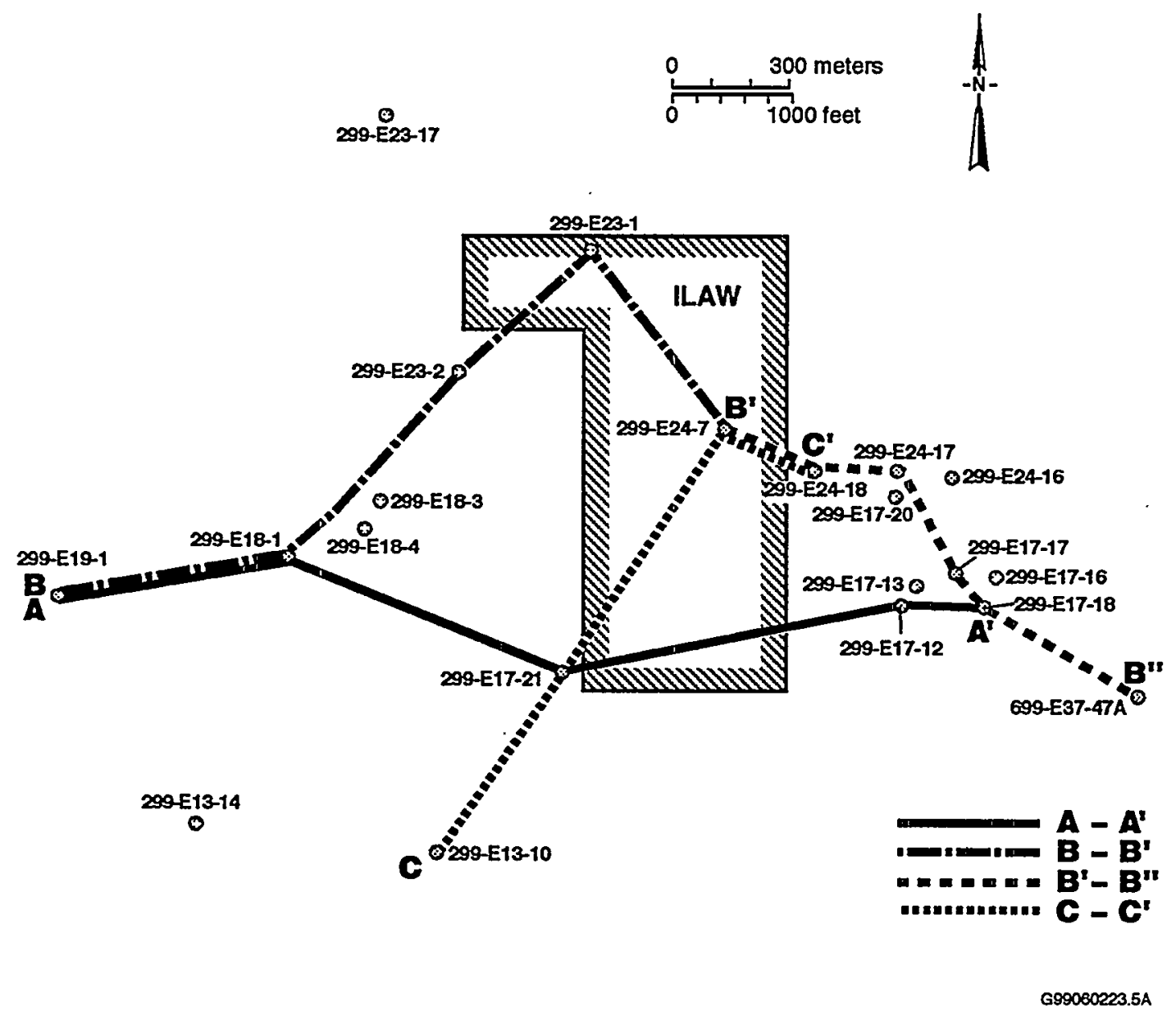

Figure 4.12. Map Showing Borehole Locations in the New ILAW Disposal Site and the Locations of Cross-Sections A-A', B-B', B'-B', and C-C'

tentative at this time because of the distance between boreholes, the poor quality of some data, and the local nature of thin units in the Hanford formation. Additional boreholes will be necessary to verify these correlations.

\subsubsection{Columbia River Basalt Group}

Previous studies (DOE 1988; Reidel and Fecht 1994a) have shown that the youngest lava flows of the Columbia River Basalt Group at the 200-East Area are those of the 10.5 million-year old Elephant Mountain Member. The Elephant Mountain Member is continuous beneath the new disposal site. No erosional windows are known or suspected to occur in the new ILAW disposal site area. 


\section{A \\ West}

\section{9-E19-1}

El. $736^{\prime}$
299-E18-1

El. $720^{\prime}$
299-E17-21

El. $735^{\prime}$

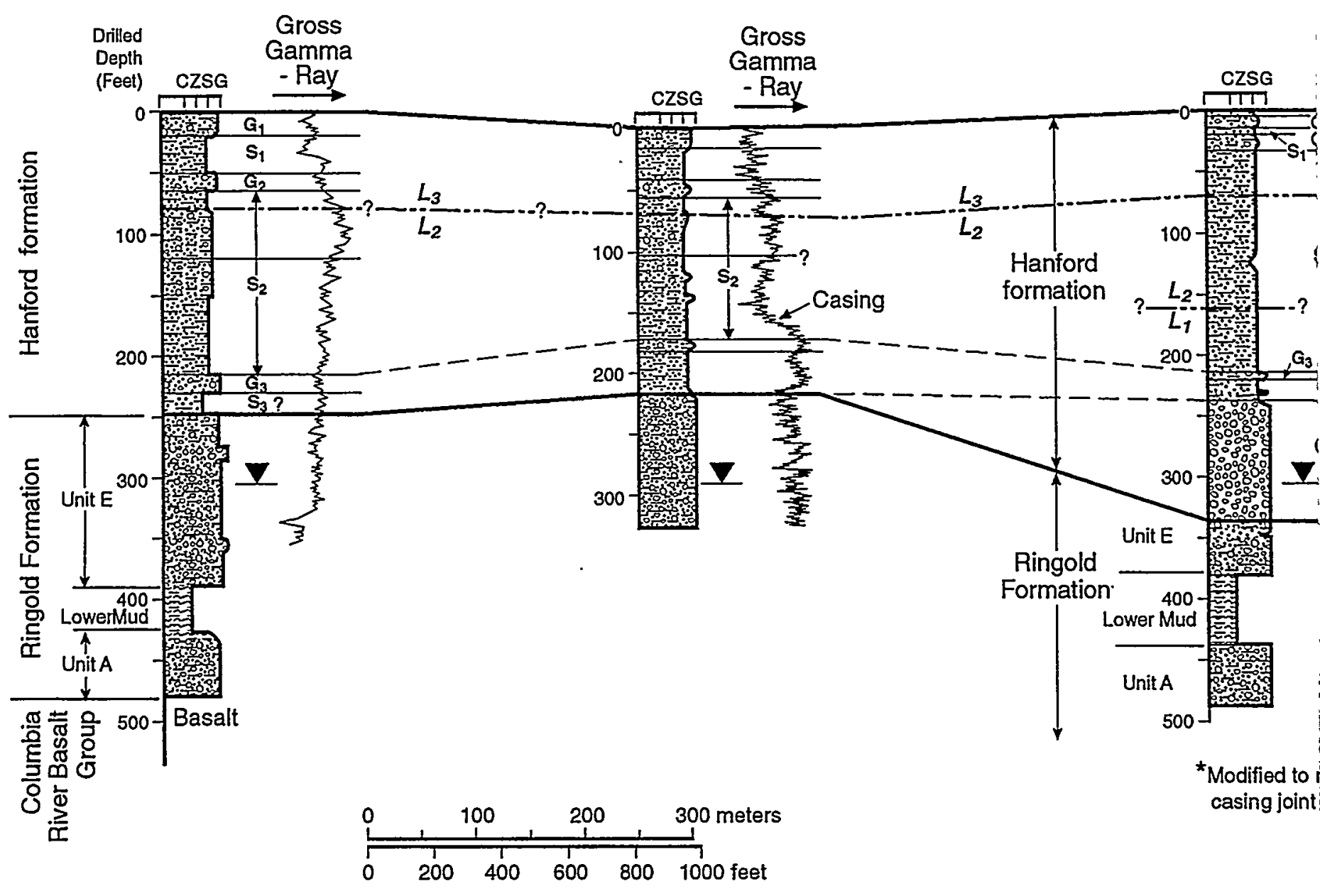

Figure 4.13. Cross-Section A-A 


\section{$A^{\prime}$ \\ East}

299-E17-17

El. $717^{\prime}$
299-E17-18

El. $720^{\prime}$
Gross

Gamma
Gross

Gamma Elevation

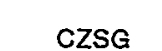

CZSG - Ray

Feet Meters

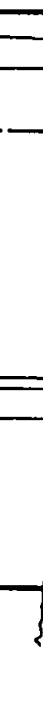

$\frac{\text { CZSG }}{\text { Th }}$

\section{.}

Sand

$$
\text { Sequence }
$$

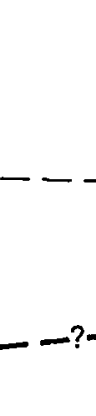

(1)

$$
\text { Gravel }
$$

Sequence

\begin{tabular}{|l}
\hline CzSG Clay, Silt, Sand, Grave \\
\hline Sandy Silt to Silty Sand \\
Sand \\
Muddy Sand \\
Slightly Gravelly Sand \\
Gravelly Sand
\end{tabular}

a Tentative Correlations
Hanford

Water Table

Muddy Sandy Gravel

Sandy Gravel

[9: Gravel

Cobbles/Boulders

Muddy Clay Units $^{\mathrm{a}}$

$G_{1}$

$s_{1}$

$G_{2}$

$S_{2}$

$G_{3}$

$S_{3}$

$G_{4}$

G09060223.3

cross the New ILAW Disposal Site 


\section{B \\ West}

\section{9-E19-1}

El. $736^{\prime}$
299-E18-1

El. $720^{\circ}$

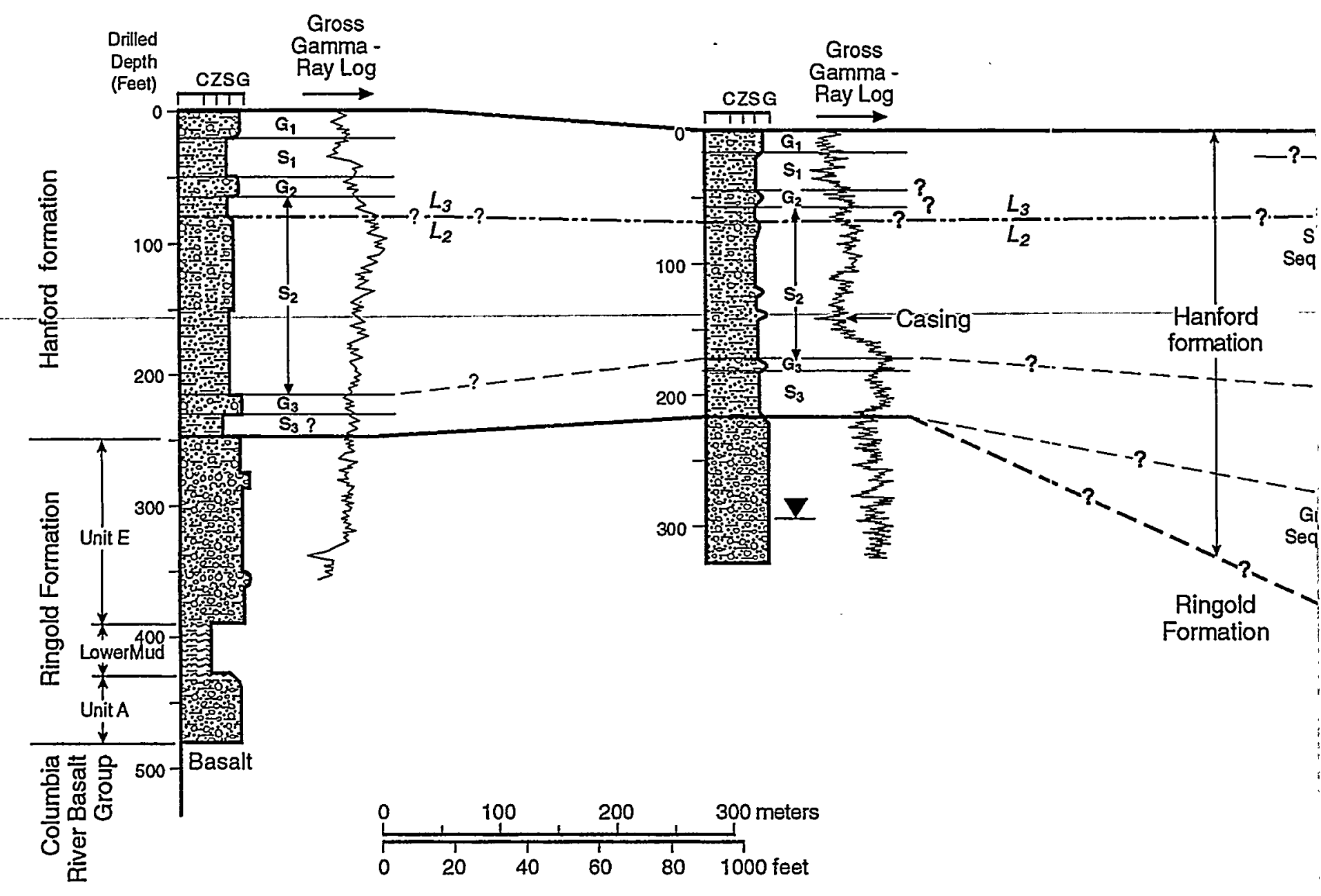

Figure 4.14. Cross-Section B-B' Act 


\section{$B^{\prime}$ \\ Northwest}

299-E24-7

El. $716^{\prime}$
299-E24-18

El. $716^{\prime}$
299-E24-17

El. $716^{:}$
299-E17-17

El. $717^{\prime}$
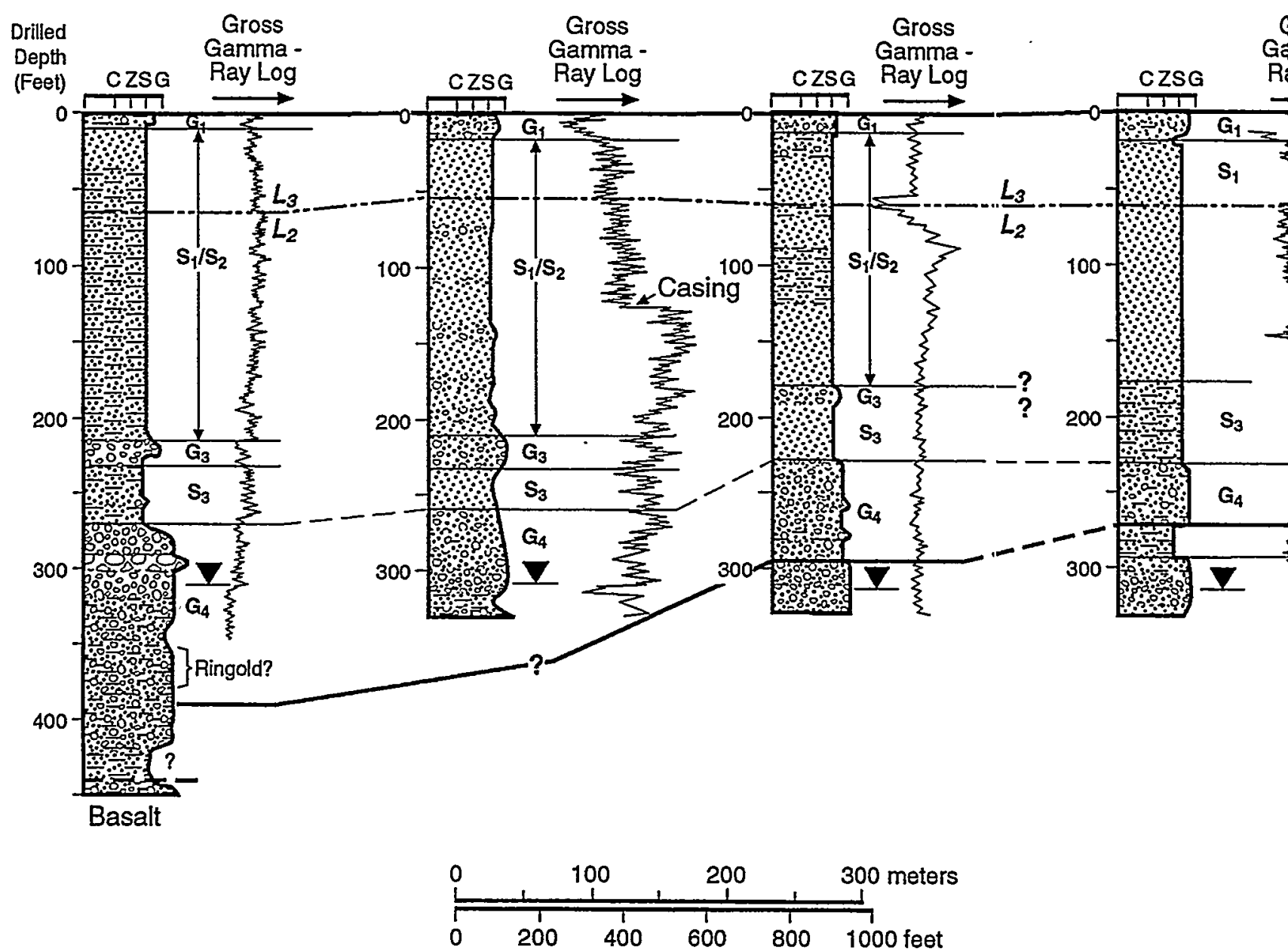

Figure 4.15. C'ross-Section B'-B" Acros 


\section{B" \\ Southeast}

299-E17-18

El. $720^{\circ}$
699-37-47A

El. $717^{1}$

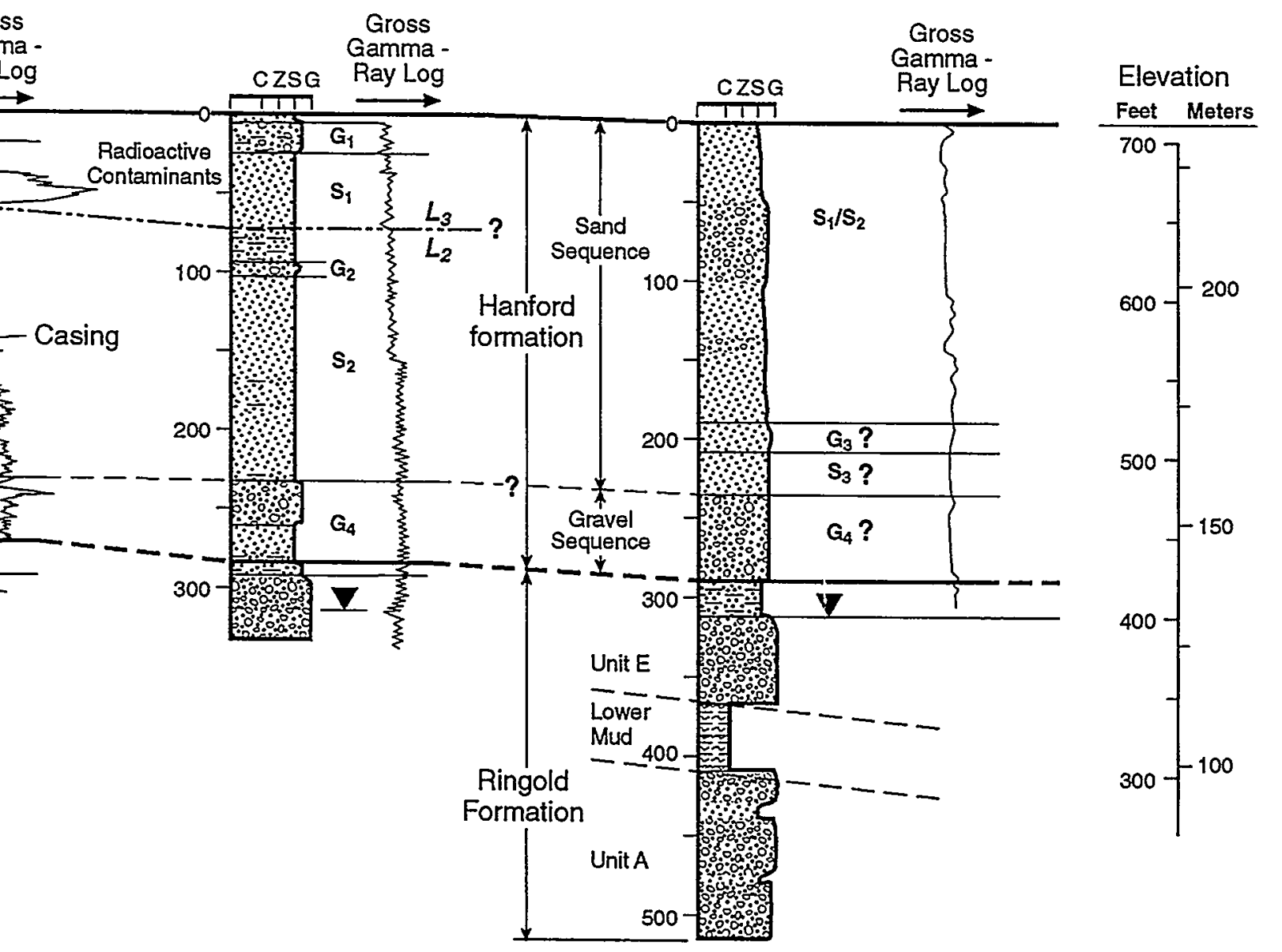

he New ILAW Disposal Site

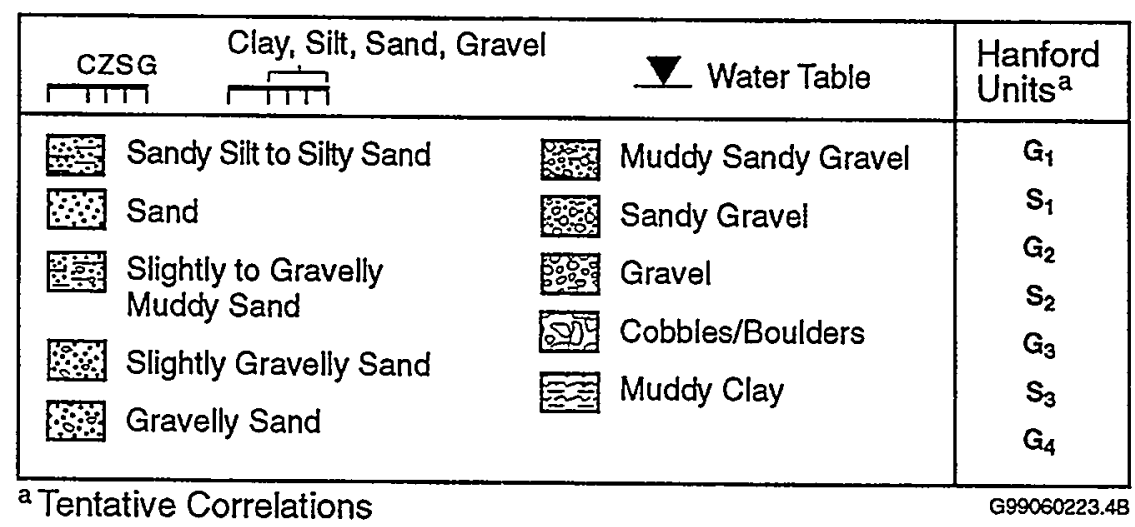




\section{C \\ Southwest}

299-E13-10

EI. $735^{4}$
299-E17-21

El. $735^{\prime}$
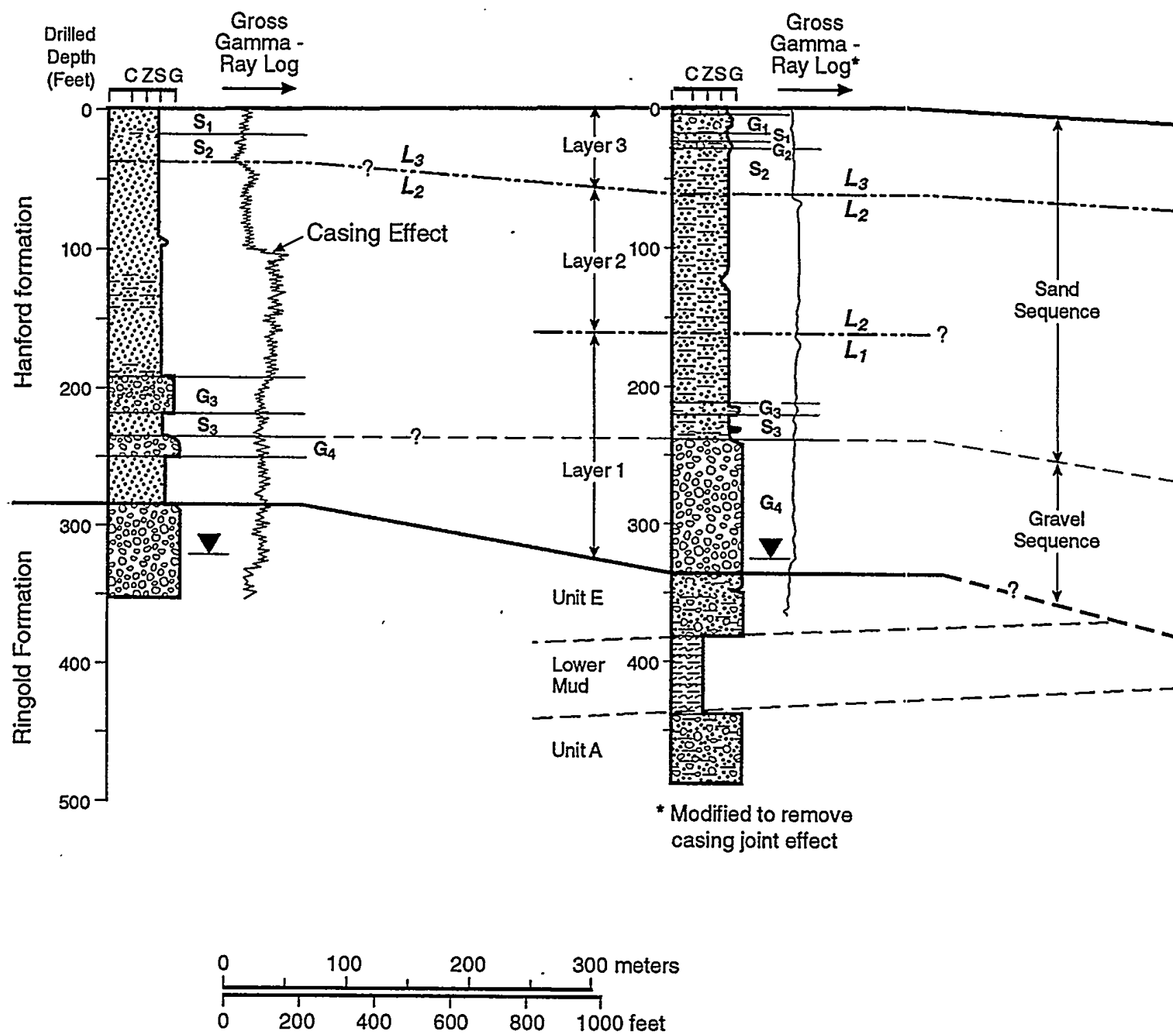

Figure 4.16. Cross-Section C-C' Across 


\section{$C^{\prime}$ \\ Northeast}

\section{9-E24-7}

El. $716^{\prime}$
299-E24-18 .

El. $716^{\prime}$

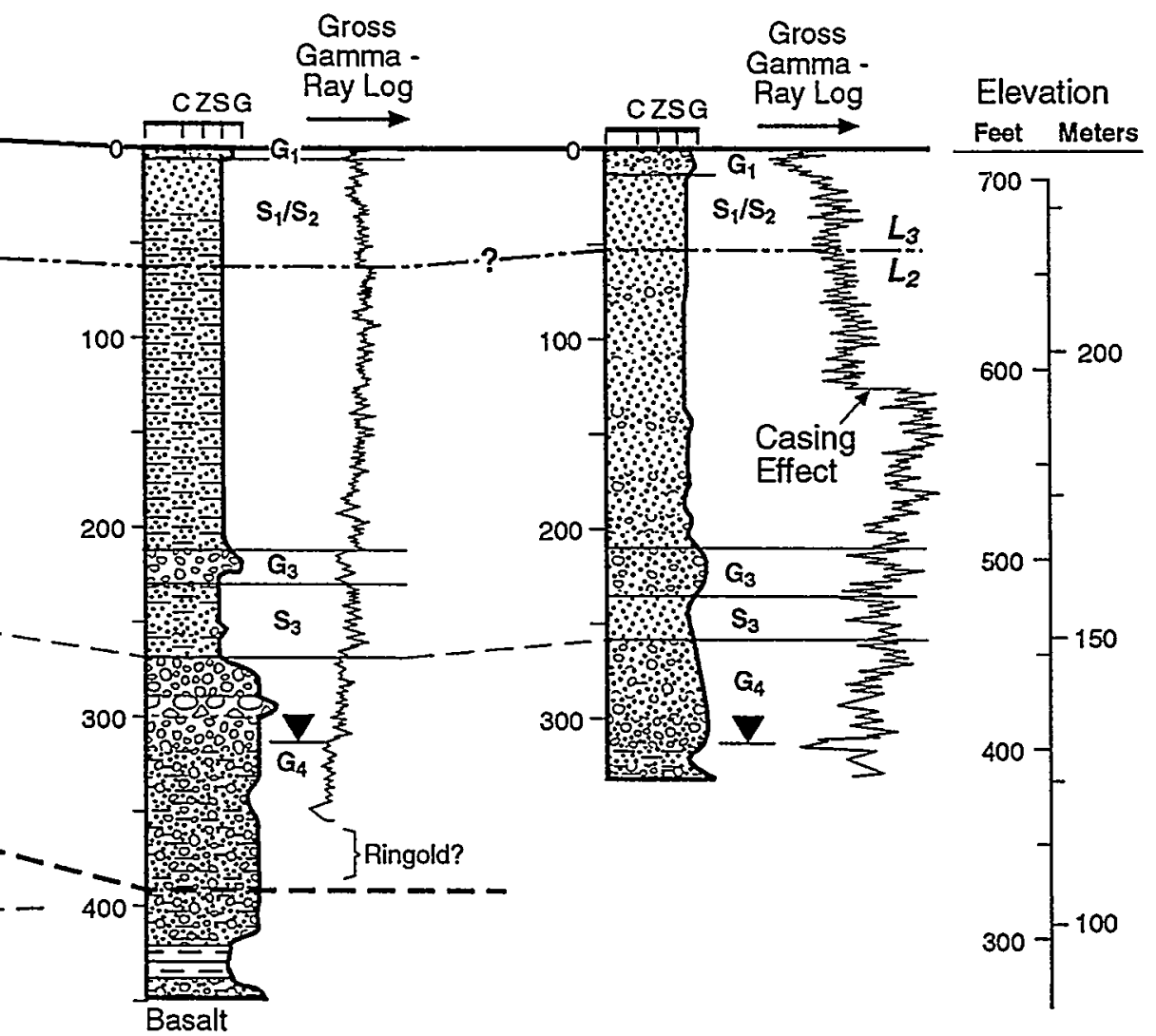

\begin{tabular}{|c|c|c|c|}
\hline $\begin{array}{c}\text { CZSG } \\
\qquad I 11 \\
\end{array}$ & Clay, Sitt, Sand, Gravel & $\varnothing$ Water Table & $\begin{array}{l}\text { Hanford } \\
\text { Units }^{\mathrm{a}}\end{array}$ \\
\hline \multicolumn{2}{|c|}{ Sandy Silt to Silty Sand } & Muddy Sandy Gravel & $\mathrm{G}_{1}$ \\
\hline \multicolumn{2}{|c|}{ Sand } & Sandy Gravel & $s_{1}$ \\
\hline \multirow{2}{*}{\multicolumn{2}{|c|}{$\begin{array}{l}\text { Slightly to Gravelly } \\
\text { Muddy Sand }\end{array}$}} & 品哭承 Gravel & $\mathrm{G}_{2}$ \\
\hline & & 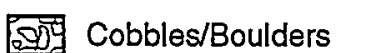 & $\mathrm{G}_{2}$ \\
\hline \multicolumn{2}{|c|}{ Slightly Gravelly Sand } & $\approx$ Muddy Clay & $S_{3}$ \\
\hline \multicolumn{3}{|c|}{ Gravelly Sand } & $\mathrm{G}_{4}$ \\
\hline
\end{tabular}

a Tentative Correlations

New ILAW Disposal Site 


\subsubsection{Ringold Formation}

Because few boreholes penetrate much of the entire Ringold Formation at the new ILAW disposal site (Figure 4.17), data are limited. The Ringold Formation reaches a maximum thickness of 285 ft $(95 \mathrm{~m})$ on the west side of the new ILAW disposal site and thins eastward. It consists of three units of Lindsey's (1996) member of Wooded Island. The member of Taylor Flats has been identified in torehole 699-47-37A (Lindberg et al. 1997) east of the site but this correlation was tentative. The deejest unit encountered is the lower gravel, Unit A. Lying above Unit A is the Lower Mud and overlying the Lower Mud is an upper gravel, Unit $E$. The upper Ringold (sand and silt of the member of Taylor Flat) is not present at the new ILAW disposal site (Figure 4.11). Unit $A$ and Unit $E$ are equivalent to mapping unit PLMcg (Figure 4.2), Pliocene-Miocene continental conglomerates of Reidel and Fecht (1994a, 1994b). The Lower Mud is equivalent the mapping unit PLMc, Pliocene-Miocene continental sand, silt, and clay beds of Reidel and Fecht (1994a, 1994b).

\subsection{Unit $A$}

Only 3 boreholes penetrated Unit $A$ in the study area (Table 4.2). Unit $A$ is $61 \mathrm{ft}(19 \mathrm{~m})$ thick on the west side of the new ILAW site but thins to the northeast (Figure 4.11). Unit A is described on bcrehole

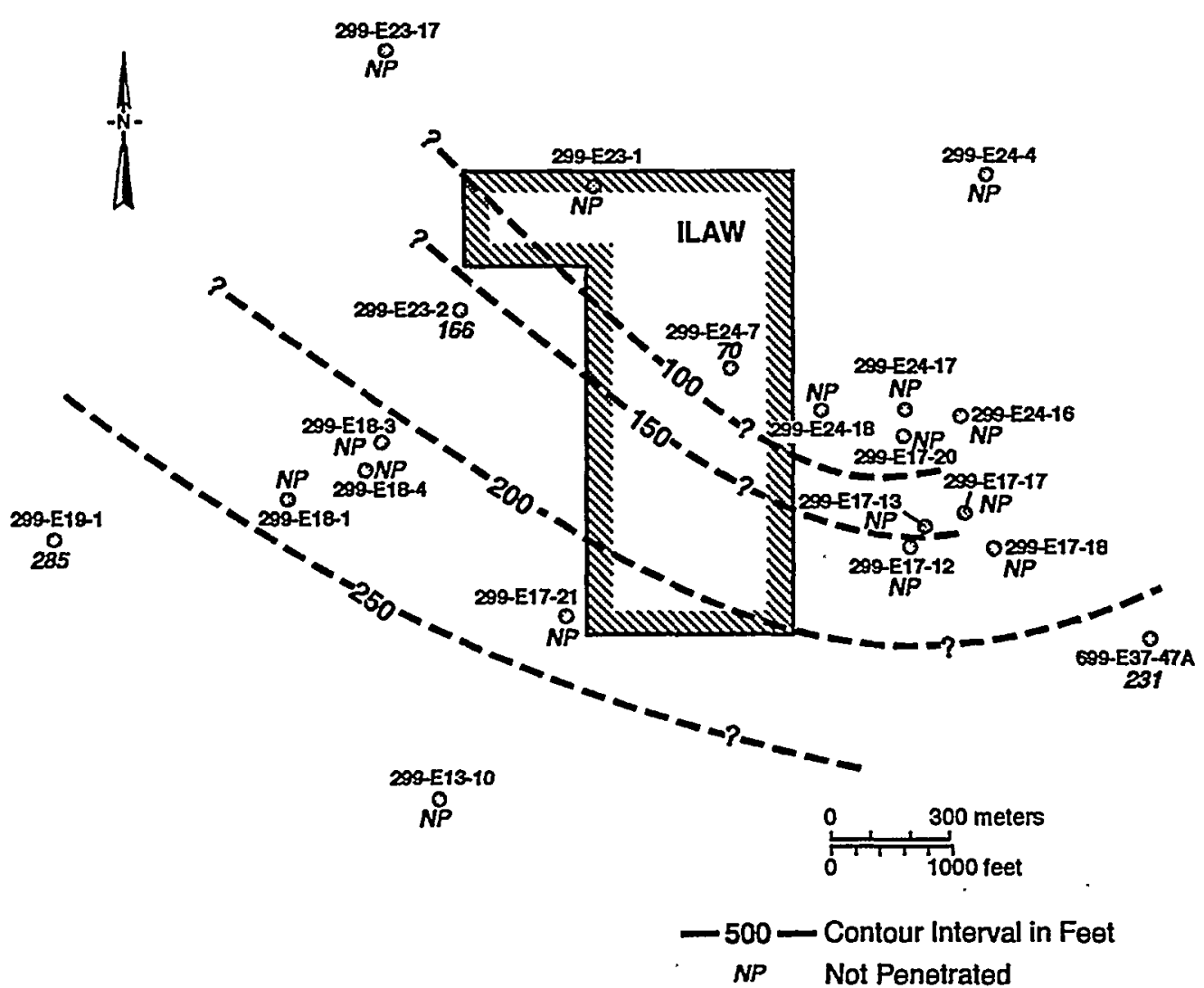

699060223.23

Figure 4.17. Isopach Map of the Ringold Formation at the New ILAW Disposal Site 
logs as a sandy gravel consisting of both felsic and basaltic rocks. It is interpreted as Lindsey's (1996) fluvial gravel facies, which consists of conglomerates and is interpreted to be similar to Unit $A$ in the existing disposal site (Section 4.2.2.2). There are sporadic yellow to white interbedded sands and silts with silt and clay lenses. Green-colored, reduced-iron stain is present on some grains and pebbles. Although the entire unit appears to be partially cemented, the zone produced abundant water in borehole 299-E17-21 (Reidel et al. 1998).

\subsection{Lower Mud}

Sixty-one feet $(19 \mathrm{~m})$ of the Lower Mud was encountered at the new ILAW site characterization borehole (299-E17-21). The upper most part (about $4 \mathrm{ft}[1 \mathrm{~m}]$ ) is described on borehole logs as a yellow sandy to silty mud and is interpreted as Lindsey's (1996) lacustrine facies, which consists of clays, silts, and silty sands. The silty clay grades downward into about $34 \mathrm{ft}(10 \mathrm{~m})$ of blue clay with beds of silt to slightly silty clay. The blue clay, in turn, grades down into $23 \mathrm{ft}(7 \mathrm{~m})$ of brown silty clay with organic rich zones and occasional wood fragments. The Lower Mud is absent in the center of the new ILAW site (Figure 4.11; boreholes 299-E23-1 and 299-E24-7).

\subsection{Unit E}

Unit $\mathrm{E}$ is described on borehole logs as a sandy gravel to gravelly sand. It is interpreted to consist of as much as $50 \mathrm{ft}(15 \mathrm{~m})$ of conglomerate with scattered cobbles up to $10 \mathrm{in}$. $(25 \mathrm{~cm})$ in size. The conglomerate consists of both felsic and basaltic clasts which are well rounded with a sand matrix supporting the cobbles and pebbles. Cementation of this unit ranges between slight and moderate. The upper contact of Unit $E$ is not easily identified at the new ILAW site. In the western part of the study area, unconsolidated gravels of the Hanford formation directly overly the Ringold Unit E gravels. The dominance of basalt in the Hanford formation and the absence of any cementation are the key criteria used for distinguishing them here (Reidel et al. 1998). In the central and northeast part of the study area, Unit E is interpreted to have been eroded (e.g., boreholes 299-E24-7 and 299-E17-21, Figure 4.11). Unconsolidated gravels and sands typical of the Hanford formation replace them.

\subsection{Upper Ringold (Member of Taylor Flat)}

The upper Ringold is not present at the new ILAW disposal site but has been tentatively identified in the southeast corner of 200-East Area in borehole 699-E37-47A (Lindberg et al. 1997). These sediments do not appear to be present at the new ILAW disposal site (Figure 4.11).

\subsection{Unconformity at Top of Ringold Formation}

The surface of the Ringold Formation is irregular in the new ILAW disposal site area (Figure 4.18). A NW-SE trending erosional channel or trough is centered along the northeast portion of the site (Figures 4.11 and 4.18). The deepest portion of the trough occurs near borehole 299-E24-7 in the northern portion of the new ILAW disposal site. This trough is interpreted to be a smaller part of a much larger trough under the 200-East Area resulting from scouring by the Missoula floods or post-Ringold fluvial incision prior to the Missoula floods. 


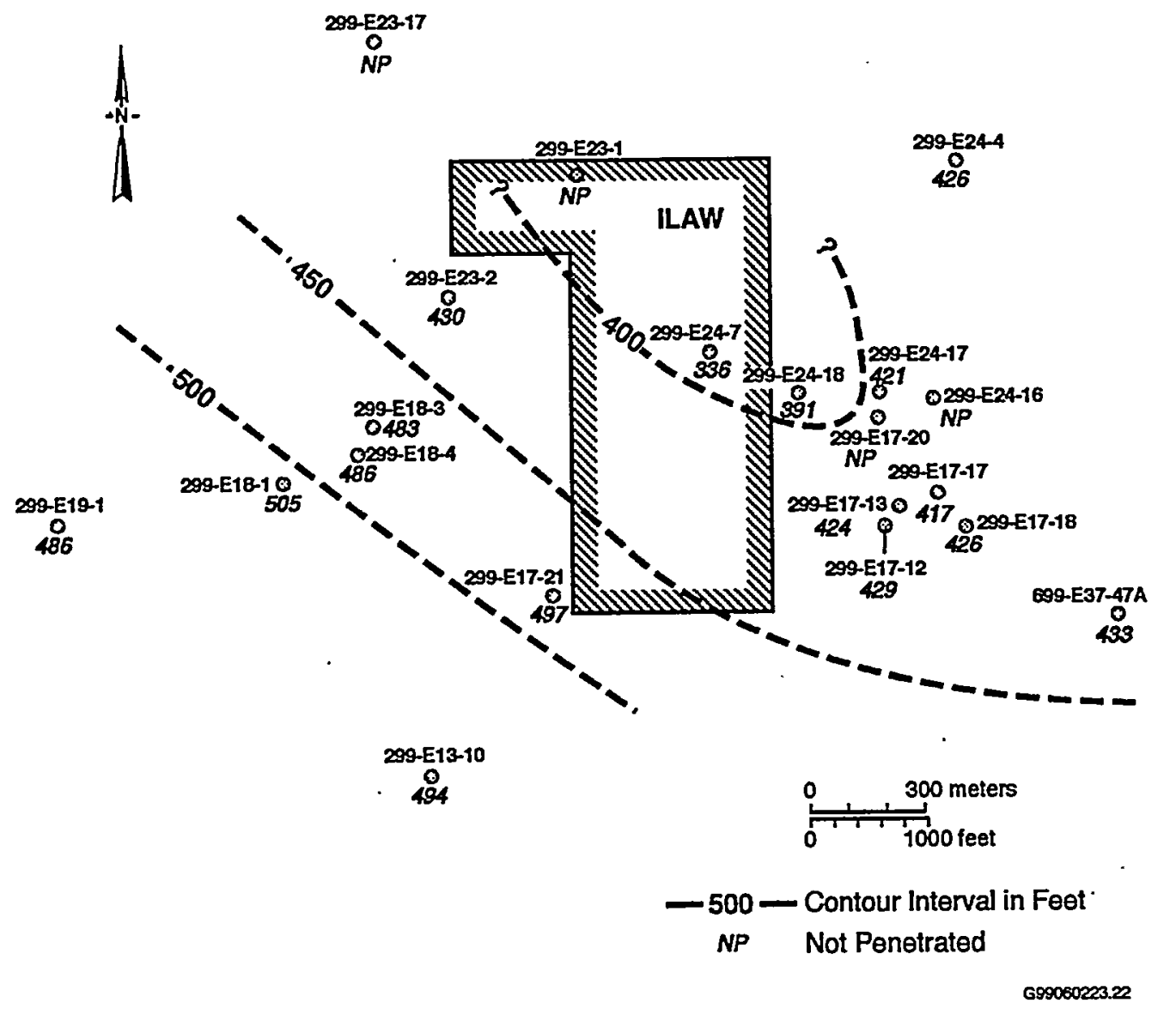

Figure 4.18. Structural Contour Map on the Surface of the Ringold Formation

\subsubsection{Hanford Formation}

The Hanford formation is as much as $380 \mathrm{ft}(116 \mathrm{~m})$ thick in and around the new ILAW disposal site (Figures 4.11 and 4.19). It thickens in the erosional channel cut into the Ringold Formation and thins to the southwest along the margin of the trough. It may thin northeast of the trough but this is based on only one data point (Figure 4.19).

At the new ILAW site, the Hanford formation consists mainly of sand-dominated facies and lesser amounts of silt-dominated and gravel-dominated facies. It has been described on borehole logs as poorly sorted pebble to boulder gravel and fine- to coarse-grained sand, with lesser amounts of interstitial and interbedded silt and clay. In previous studies of the new ILAW disposal site (Reidel et al. 1998), the Hanford formation was described as consisting of three units: an upper and lower gravel-dominated facies and a sand-dominated facies between the two gravel facies. The upper gravel-dominated facies appears to be thin or absent in the new ILAW disposal area. In Table 4.2, the elevations of the tops of several tentatively correlated units of the Hanford formation are given. 


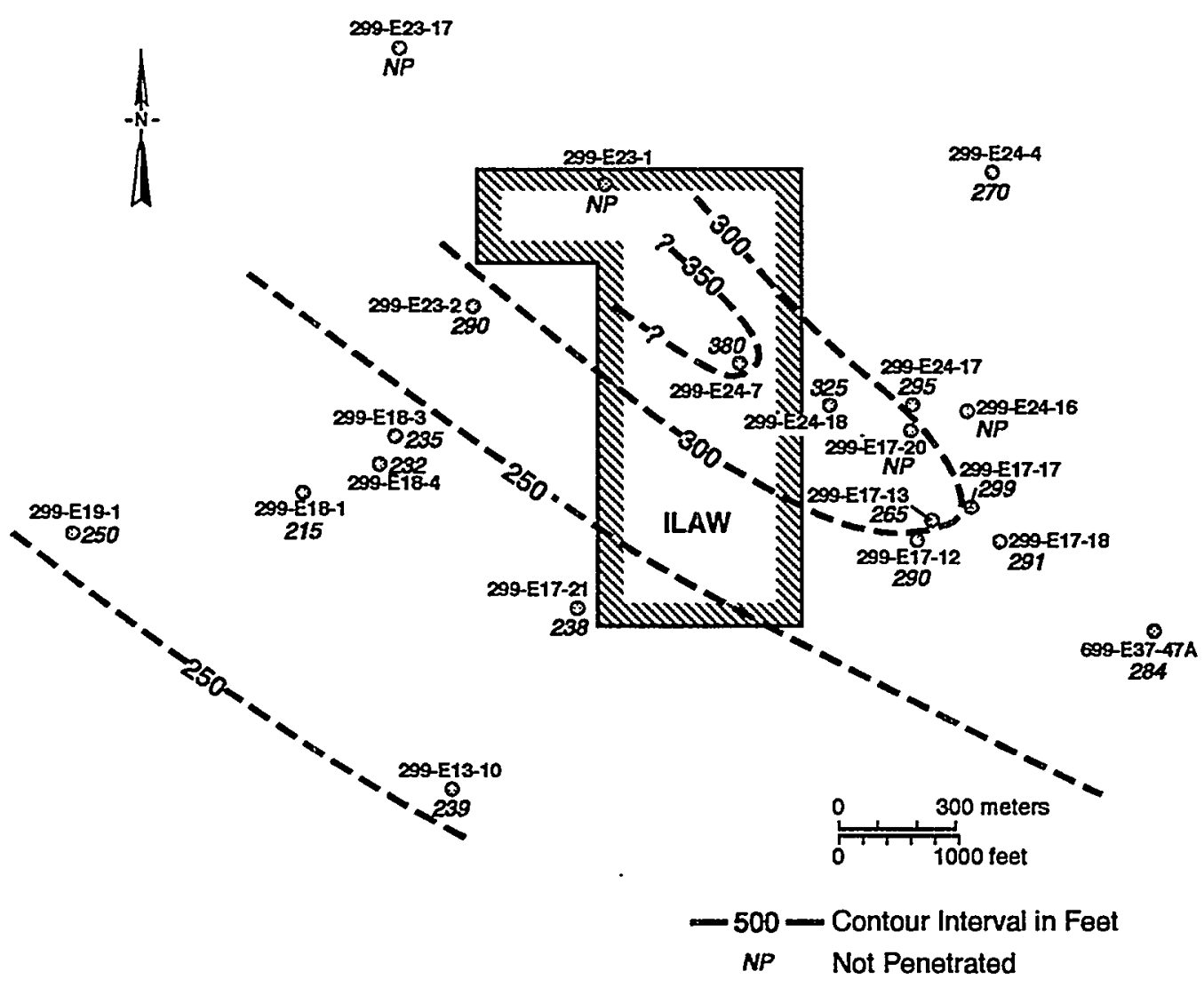

G80060223 24

Figure 4.19. Isopach Map of the Hanford Formation at the New ILAW Disposal Site

\subsection{Basal Gravel Sequence}

The lowermost $88 \mathrm{ft}(27 \mathrm{~m})$ of the Hanford formation encountered in borehole 299-E17-21 consists of gravel-dominated facies. Drill core and cuttings from this borehole indicate that the unit is clastsupported pebble- to cobble-gravel with minor amounts of sand in the matrix. Cobbles and pebbles are almost exclusively basalt with no cementation. In outcroppings these deposits display massive bedding, plane to low-angle bedding and large-scale planar forset cross-bedding, but such features typically cannot be observed in borehole core. This unit either pinches out west of the new ILAW disposal site or becomes more sand rich. It thickens to the northeast. The gravel is interpreted to be Missoula flood gravels deposited in the erosional channel carved into the underlying Ringold Formation (Figure 4.18).

This basal gravel sequence is equivalent to unit $\mathrm{H} 3$ of Lindsey et al. (1994b) (Figure 4.2), and is equivalent to mapping unit Qfg1, Missoula Outburst flood gravel deposits of Reidel and Fecht (1994a, 1994b). The sand unit overlying this gravel has reversed polarity (Appendix B), indicating that these units are older than $780 \mathrm{ka}$. 


\subsection{Sandy Sequence}

The upper portion of the Hanford formation consists of at least $240 \mathrm{ft}(73 \mathrm{~m})$ of sand-dominated and silt-dominated facies. These deposits have been described as fine- to coarse-grained sand with minor amounts of silt and clay and some gravelly sands. This sequence is equivalent to unit $\mathrm{H} 2$ of Lindsizy et al. (1994a), and is equivalent to the following mapping units of Reidel and Fecht (1994a,b): Qfs1, Qf's2, and Qfs3, Missoula Outburst Flood Deposits consisting of sand, silt, and clay (Figure 4.2).

Three paleosols (soils) were identified in core and drill cuttings from borehole 299-E17-21 (Rijidel et al. 1998). Paleosol Horizon 1 occurs at $163 \mathrm{ft}(49 \mathrm{~m})$ drilled depth (Figure 4.11), paleosol Horizon 2 at $58 \mathrm{ft}(18 \mathrm{~m})$ drilled depth, and paleosol Horizon 3 at $5 \mathrm{ft}(1.5 \mathrm{~m})$. The paleosol horizons are as rnuch as 6 in. $(15 \mathrm{~cm})$ thick with a sharp upper surface. The horizons have a light brown color compared to the darker sands below and some $\mathrm{CaCO}_{3}$ cementation. The lack of well-defined bedding laminations rhythmics like the sands below suggests some bioturbation but no root casts were observed in the core. The paleosol grades downward into normal sands.

The three paleosol horizons represent time intervals when soil development took place and are interpreted to represent three time periods between Missoula flood deposition. Reidel et al. (1998) called the layers defined by the paleosols: Layer 1 as that part of the Hanford formation extending from the paleosol horizon at $163 \mathrm{ft}(49 \mathrm{~m})$ to the top of the basalt gravel at $247 \mathrm{ft}(75 \mathrm{~m})$. Layer 2 extends from the top of the second paleosol horizon $58 \mathrm{ft}(18 \mathrm{~m})$ to the top of the first paleosol at $163 \mathrm{ft}(49 \mathrm{~m})$. Layer 3 extends from the top of the third paleosol horizon at $5 \mathrm{ft}(1.5 \mathrm{~m})$ depth to the second paleosol horizon at $58 \mathrm{ft}(18 \mathrm{~m})$ drilled depth. The presence or exact depth of these layers is known elsewhere at the rew ILAW site and can only be inferred.

Layer 1. Layer 1 is $84 \mathrm{ft}(26 \mathrm{~m})$ thick in borehole 299-E17-21. It is a zone of sand and silt with a poorly developed caliche layer at the top. Only the upper several inches are cemented but $\mathrm{CaCO}_{3}$ extends to a depth of about $10 \mathrm{ft}(3.3 \mathrm{~m})$ below the top. $\mathrm{CaCO}_{3}$ fragments or grain coatings were found to a depth of at least $218 \mathrm{ft}(66 \mathrm{~m})$.

The lower $20 \mathrm{ft}(6 \mathrm{~m})$ of Layer 1 consists of interbedded sands and gravels. The basal gravel sequence underlying Layer 1 appears to grade upward into a sequence of interbedded sands and gravels. At least three upward fining zones of gravels to sands were recognized in Layer 1. These zones are equivalent to unit H2A of Lindsey et al. (1994a).

Planar-laminar sands with minor silt lenses dominate the upper $54 \mathrm{ft}(16 \mathrm{~m})$ of Layer 1 . This sequence consists of fining upward sands, well-compacted, slightly $\mathrm{CaCO}_{3}$-cemented sands, and welllaminated sands. $\mathrm{CaCO}_{3}$ associated with development of the paleosol extends well down into this layer.

Layer 1 is part of unit $\mathrm{H} 2$ of Lindsey et al. (1994a), and is equivalent to mapping unit Qfs1 of Reidel and Fecht (1994a, 1994b) (Figure 4.2). Mapping unit Qfs1 is a Missoula Outburst Flood Deposit; consisting of sand, silt, and clay that is $780 \mathrm{ka}$ and has a reversed magnetic polarity. Paleomagnelic studies by the University of California, Santa Cruz, has shown that this layer has reversed magnetic 
polarity (Appendix B). Layer 1 has only been identified in borehole 299-E17-21. Data from surrounding boreholes is of too poor of quality to identify this layer.

Layer 2. The upper $90 \mathrm{ft}(27 \mathrm{~m})$ of Layer 2 is principally the sand- and silt-dominated facies. They have been described as fine- to medium-grained sand with minor amounts of interstitial silt. Throughout the sands are disseminated flakes of $\mathrm{CaCO}_{3}$ and $\mathrm{CaCO}_{3}$-cemented sand grains. Several fining upward zones were recognized as well as highly-compacted zones of sand and silt with faint laminations. Layer 2 was correlated to other boreholes using geologists logs and archived chip samples. In addition, the paleosol that forms the top of this layer appears to responsible for zones of lateral spreading of contaminants under waste disposal sites immediately east of the new ILAW disposal site.

Layer 2 is also part of unit $\mathrm{H} 2$ of Lindsey et al. (1994a), and may be equivalent to mapping unit Qfs2 of Reidel and Fecht (1994a, 1994b) (Figure 4.2). The mapping unit is a Missoula Outburst Flood Deposits consisting of sand, silt and clay that is older than $13 \mathrm{ka}$ and younger than $780 \mathrm{ka}$. Mapping unit Qfs2 has a normal magnetic polarity.

Layer 3. Layer 3 is $53 \mathrm{ft}(16 \mathrm{~m})$ thick in borehole 299-E17-21. The paleosol at the top of Layer 3 is a $1.1 \mathrm{ft}(3 \mathrm{~cm})$ thick, oxidized and leached zone of pebbly, fine-grained sand and silt with some pebbles with a 4-in. $(10-\mathrm{cm})$ poorly developed caliche zone (sand and silt cemented by $\mathrm{CaCO}_{3}$ ). Several distinct gravelly sands are present within several feet of the paleosol at the top of this layer. This forms the surface of much of the new ILAW disposal site north of the eolian deposits.

The lower 25 to $30 \mathrm{ft}$ ( 8 to $10 \mathrm{~m}$ ) of Layer 3 consists principally of sand with interstitial silt and minor silt beds that are interpreted as lenses. Several minor silt beds are locally present. Gravelly sand as described on geologists logs marks a transition to finer-grained sand with more silt at a drilled depth of approximately $25 \mathrm{ft}(8 \mathrm{~m})$.

Layer 3 is interpreted to consist of the upper gravelly sequence and the upper part of the sandy sequence defined in previous studies. It is part of unit H2 of Lindsey et al. (1994) and is equivalent to mapping unit Qfs3 of Reidel and Fecht (1994a, 1994b) - Outburst Flood Deposits consisting of sand, silt and clay that is about $13 \mathrm{ka}$. An ash from the $13 \mathrm{ka}$ eruption of Mt. St. Helens (Set S Ash) is typically found near the top of this unit in many places throughout the Pasco basin. The ash was not recognized in any of the boreholes near the new ILAW disposal site but has been identified as an excavation $100 \mathrm{~m}$ west of the site.

\subsubsection{Eolian Unit}

Eolian deposits cover the southern part of the new ILAW disposal site. Borehole 299-E17-21 was sited on a stabilized sand dune. The eolian unit is composed of fine- to coarse-grained sands with abundant silt. Calcium-carbonate coating found on the bottom of pebbles and cobbles in drill core through this unit is typical of Holocene caliche development in the Columbia Basin. This unit is equivalent to mapping unit Qd, Holocene Dune Sand, of Reidel and Fecht (1994a, 1994b) (Figure 4.2). 


\subsubsection{Clastic Dikes at the New ILAW Site}

Clastic dikes have not been observed at the new ILAW site. Clastic dikes, however, have been observed in excavations surrounding the site (e.g., PUREX, US Ecology, and Canister Storage exsavation). At the new ILAW site, clastic dikes are probably not observed because they are covered by wind blown sediments and a cover of "old growth" sagebrush. The ubiquitous presence of clastic dikes in the 200-East Area suggests that they are probably present at the site. 


\subsection{Seismic Data}

Earthquake activity at the new and existing disposal sites is typical of the Hanford Site. Figure 5.1 shows the location of earthquakes that have occurred near the 200-East Area since monitoring began at Hanford in 1969. Table 5.1 summarizes the pertinent data for the earthquakes shown on Figure 5.1. Most of the earthquakes have been less than coda magnitude 3.0. Coda magnitude is a local magnitude and is an estimate of the Richter magnitude. Thirty-three percent of the earthquakes shown on Figure 5.1 occurred in the Columbia River Basalt Group. Sixteen percent were in the sub-basalt sediments and 51\% were in the crystalline basement.

The principal geologic structures from Reidel and Fecht (1994a) are reproduced on Figure 5.1. A comparison of the location of earthquakes to the geologic structures indicates that there is no apparent pattern.

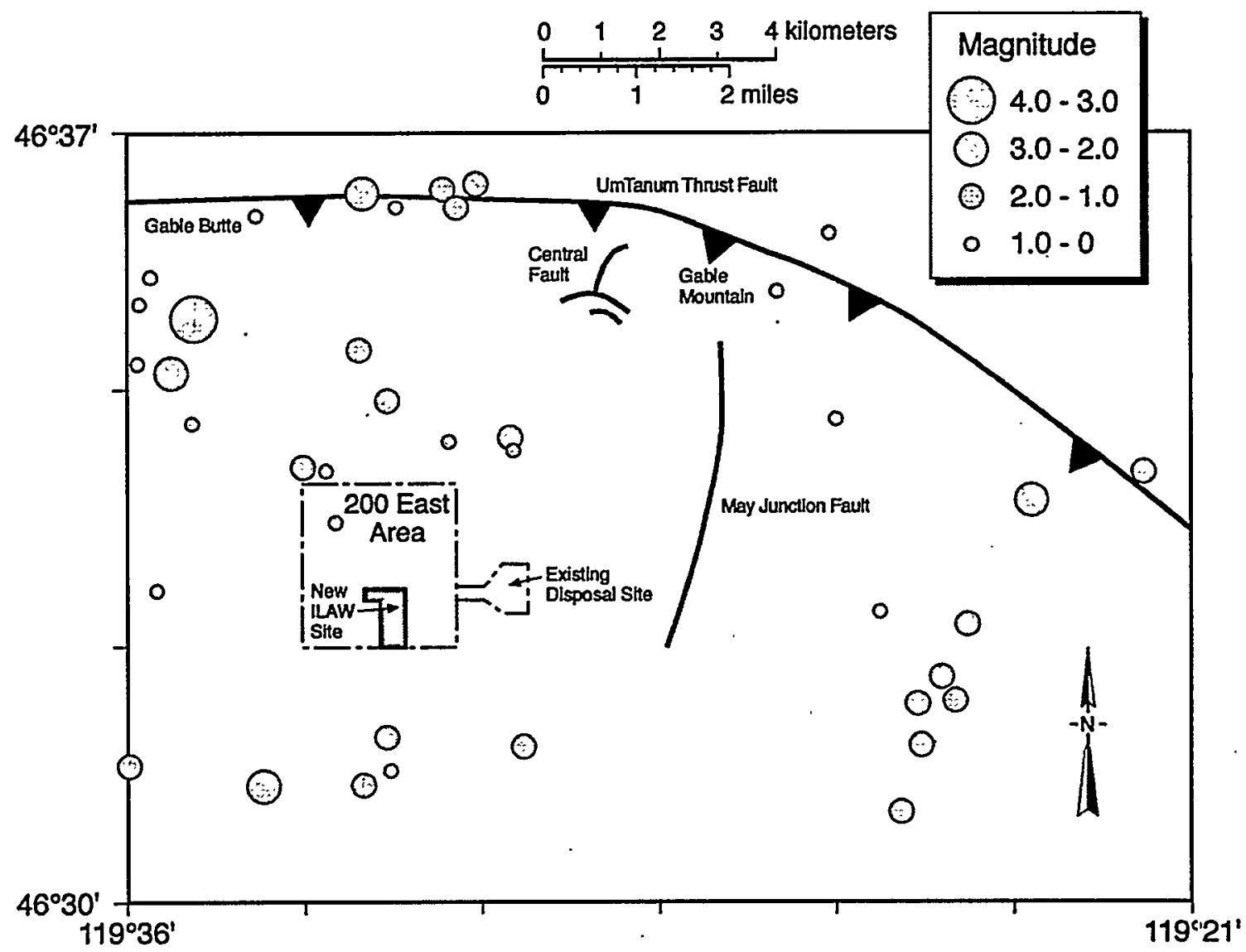

G99110022.3

Figure 5.1. Map Showing the Location of Earthquakes Detected Since 1969 
Table 5.1. Earthquakes in the Area Surrounding the Existing and New ILAW Disposal Sites

\begin{tabular}{|c|c|c|c|c|c|c|}
\hline $\begin{array}{l}\text { Event } \\
\text { Number }\end{array}$ & Date & $\begin{array}{l}\text { Latitude } \\
\text { (degrees N } \\
\text { minutes) }\end{array}$ & $\begin{array}{l}\text { Longitude } \\
\text { (degrees } \mathrm{N} \\
\text { minutes }\end{array}$ & $\begin{array}{l}\text { Depth } \\
(\mathrm{km})\end{array}$ & $\begin{array}{l}\text { Magnitude } \\
\text { (coda) }\end{array}$ & Geologic Layer \\
\hline 7003161548 & $3 / 16 / 70$ & $46 \mathrm{~N} 31$ & $119 W 34$ & 21.5 & 2.1 & Crystalline Basement \\
\hline 7110132218 & $10 / 01 / 71$ & $46 \mathrm{~N} 34$ & $119 \mathrm{~W} 31$ & 18.2 & 1.0 & Crystalline Basement \\
\hline 7302111101 & $2 / 11 / 73$ & $4 \cong \mathrm{N33}$ & $119 W 36$ & 13.56 & 0.6 & Crystalline Basement \\
\hline 7506161959 & $6 / 16 / 75$ & $46 \mathrm{N37}$ & $119 W 33$ & 4.65 & 2.5 & Basalt \\
\hline 7501282012 & $10 / 28 / 75$ & $46 \mathrm{~N} 35$ & $119 \mathrm{~W} 32$ & 19.02 & 1.0 & Crystalline Basement \\
\hline 7805111831 & $5 / 11 / 78$ & $46 \mathrm{~N} 36$ & $119 W 27$ & 16.37 & 0.8 & Crystalline Basement \\
\hline 7805151210 & $5 / 15 / 78$ & $46 \mathrm{~N} 32$ & $119 W 25$ & 17.79 & 1.5 & Crystalline Basement \\
\hline 7808170243 & $8 / 17 / 78$ & $46 \mathrm{~N} 37$ & $119 W 31$ & 4.91 & 1.0 & Basalt \\
\hline 7808190250 & $8 / 19 / 78$ & $46 \mathrm{~N} 37$ & $119 W 31$ & 6.85 & 1.2 & Sub-basalt Sediments \\
\hline 7808221820 & $8 / 22 / 78$ & $46 \mathrm{~N} 37$ & $119 \mathrm{~W} 32$ & 0.31 & 0.7 & Basalt \\
\hline 7808242113 & $8 / 24 / 78$ & $46 \mathrm{~N} 37$ & $119 W 32$ & 4.44 & 1.0 & Basalt \\
\hline 8003252307 & $3 / 25 / 80$ & $46 \mathrm{~N} 32$ & $119 \mathrm{~W} 25$ & 2.66 & 1.3 & Basalt \\
\hline 8003262300 & $3 / 26 / 80$ & $46 \mathrm{~N} 31$ & $119 \mathrm{~W} 25$ & 1.37 & 1.3 & Basalt \\
\hline 8003292210 & $3 / 29 / 80$ & $46 \mathrm{~N} 32$ & $119 W 25$ & 3.22 & 1.2 & Basalt \\
\hline 800414733 & $4 / 14 / 80$ & $46 \mathrm{~N} 33$ & $119 W 26$ & 0.44 & 0.8 & Basalt \\
\hline 8004161834 & $4 / 16 / 80$ & $46 \mathrm{~N} 33$ & $119 W 25$ & 7.56 & 1.1 & Sub-basalt Sediments \\
\hline 8010221136 & $10 / 22 / 80$ & $46 \mathrm{~N} 34$ & $119 W 33$ & 20.87 & 0.3 & Crystalline Basement \\
\hline 8104161826 & $4 / 16 / 81$ & $46 \mathrm{~N} 31$ & $119 W 25$ & 1.27 & 1.3 & Basalt \\
\hline 8107200623 & $7 / 20 / 81$ & $46 \mathrm{~N} 34$ & $119 \mathrm{~W} 32$ & 11.99 & 0.1 & Sub-basalt Sediments \\
\hline 8108072202 & $8 / 7 / 81$ & $46 \mathrm{~N} 31$ & $119 W 36$ & 15.45 & 1.5 & Crystalline Basement \\
\hline 8312181118 & $12 / 18 / 83$ & $46 \mathrm{~N} 34$ & $119 W 34$ & 15.65 & 1.5 & Crystalline Basement \\
\hline 8612120307 & $12 / 12 / 86$ & $46 \mathrm{~N} 34$ & $119 W 31$ & 3.94 & 0.9 & Basalt \\
\hline 8707251409 & $7 / 25 / 87$ & $46 \mathrm{~N} 34$ & 119W33 & 15.59 & 0.3 & Crystalline Basement \\
\hline 8807042056 & $7 / 4 / 88$ & $46 \mathrm{~N} 36$ & $119 W 26$ & 16.62 & 0.7 & Crystalline Basement \\
\hline 9003162235 & $3 / 16 / 90$ & $46 \mathrm{~N} 31$ & 119 W33 & 7.83 & 1.2 & Sub-basalt Sediments \\
\hline 9003162236 & $3 / 16 / 90$ & $4 \mathrm{~N} 31$ & $119 W 32$ & $8.16^{\circ}$ & 0.4 & Sub-basalt Sediments \\
\hline 9003180506 & $3 / 18 / 90$ & $46 \mathrm{~N} 32$ & 119 W32 & 4.13 & 1.2 & Basalt \\
\hline 9008020211 & $8 / 2 / 90$ & $46 \mathrm{~N} 35$ & 119 W33 & 14.75 & 1.0 & Crystalline Basement \\
\hline 9011201718 & $11 / 20 / 90$ & $46 \mathrm{~N} 35$ & $119 W 35$ & 25.24 & 2.1 & Crystalline Basement \\
\hline 9201070846 & $1 / 7 / 92$ & $46 \mathrm{~N} 35$ & 119 W35 & 24.38 & 0.9 & Crystalline Basement \\
\hline 9201241911 & $1 / 24 / 92$ & $46 \mathrm{~N} 35$ & $119 W 26$ & 19.72 & 0.9 & Crystalline Basement \\
\hline 9411131510 & $11 / 13 / 94$ & $46 \mathrm{~N} 36$ & 119 W36 & 24.74 & 0.4 & Crystalline Basement \\
\hline
\end{tabular}


Table 5.1. (contd)

\begin{tabular}{|c|c|c|c|c|c|l||}
\hline $\begin{array}{c}\text { Event } \\
\text { Number }\end{array}$ & Date & $\begin{array}{c}\text { Latitude } \\
\text { (egrees N } \\
\text { minutes) }\end{array}$ & $\begin{array}{c}\text { Longitude } \\
\text { (degrees } \mathrm{N} \\
\text { minutes }\end{array}$ & $\begin{array}{c}\text { Depth } \\
(\mathrm{km})\end{array}$ & $\begin{array}{c}\text { Magnitude } \\
\text { (coda) }\end{array}$ & \multicolumn{1}{|c|}{ Geologic Layer } \\
\hline 9411131650 & $11 / 13 / 94$ & $46 \mathrm{~N} 35$ & $119 \mathrm{~W} 35$ & 28.22 & 3.3 & Crystalline Basement \\
\hline 9411242107 & $11 / 24 / 94$ & $46 \mathrm{~N} 35$ & $119 \mathrm{~W} 36$ & 25.40 & 0.7 & Crystalline Basennent \\
\hline 9412152020 & $12 / 15 / 94$ & $46 \mathrm{~N} 36$ & $119 \mathrm{~W} 36$ & 25.18 & 0.3 & Crystalline Basement \\
\hline 9603210923 & $3 / 21 / 96$ & $46 \mathrm{~N} 32$ & $119 \mathrm{~W} 31$ & 21.88 & 1.1 & Crystalline Basement \\
\hline 9708122312 & $8 / 12 / 97$ & $46 \mathrm{~N} 34$ & $119 \mathrm{~W} 24$ & 0.27 & 2.1 & Basalt \\
\hline 9809232334 & $9 / 23 / 98$ & $46 \mathrm{~N} 36$ & $119 \mathrm{~W} 34$ & 14.16 & 0.9 & Crystalline Basement \\
\hline 9901101816 & $1 / 10 / 99$ & $46 \mathrm{~N} 34$ & $119 \mathrm{~W} 22$ & 0.26 & 1.4 & Basalt \\
\hline
\end{tabular}




\subsection{References}

Baker VR, BN Bjornstad, AJ Busacca, KR Fecht, EG Kiver, UL Moody, JG Rigby, DF Stradling, and AM Tallman. 1992. "Quaternary geology of the Columbia Plateau," in RB Morrison (ed.), Quaternary geology of the conterminous United States. Geological Society of America, Boulder, Colorado, v. K-2, p. 215-238.

Bjornstad BN, KR Fecht, and AM Tallman. 1987. Quaternary stratigraphy of the Pasco Basin area south-central Washington. RHO-BW-SA-563A, Rockwell Hanford Operations, Richland, Washington.

Chamness MA and JK Merz. 1993. Hanford wells. PNL-8800, Pacific Northwest Laboratory. Richland, Washington.

Connelly et al. 1992. Hydrogeologic model for the 200 East groundwater aggregate area. WHC.-SDEN-TI-019, Westinghouse Hanford Company, Richland, Washington.

Delaney CD, KA Lindsey, and SP Reidel. 1991. Geology and hydrology of the Hanford Site: A standardized text for use in Westinghouse Hanford Company documents and reports. WHC-SD-ER-1.1-003, Rev. 0, Westinghouse Hanford Company, Richland, Washington.

Fayer MJ, EM Murphy, JL Downs, FO Khan, CW Lindenmeier, and BN Bjornstad. 1999. Recharge data package for the Immobilized Low-Activity Waste 2001 performance assessment. PNNL-130.33, Pacific Northwest National Laboratory, Richland, Washington.

Fecht KR, KA Lindsey, BN Bjornstad, DG Horton, GV Last, and SP Reidel. 1998. An Atlas of C.lastic Injection Dikes of the Pasco Basin and Vicinity. Bechtel Hanford Incorporated Report BHI-01103.

Kaplan DI and JR Serne. 1999. Geochemical Data Package for the Immobilized Low-Activity Tank Waste Performance Assessment. PNNL-13037, Pacific Northwest National Laboratory, Richland, Washington.

Khaleel R. 1999. Far-field hydrology data package for the immobilized low-activity tank waste performance assessment. HNF-4769, Rev. 0, Fluor Daniel Northwest.

Lindberg JW, JV Borghese, BN Bjornstad, and MP Connelly. 1993. Geology and aquifer charaiteristics of the Grout Treatment Facility. WHC-SD-EN-TI-071, Westinghouse Hanford Company, Richland, Washington.

Lindberg JW, BA Williams, and FA Spane. 1997 Borehole data package for well 299-E37-47A, PUREX cribs. PNNL-11515, Pacific Northwest National Laboratory, Richland, Washington. 
Lindsey KA, BN Bjornstad, JW Lindberg, and KM Hoffman. 1992. Geologic setting of the 200 East Area; an update. WHC-SD-EN-TI-012, Rev. 0, Westinghouse Hanford Company, Richland, Washington.

Lindsey KA. 1996. The Miocene to Pliocene Ringold Formation and associated deposits of the ancestral Columbia River system, south-central Washington and north-central Oregon. Washington Division of Geology and Earth Resources Open-file Report 96-8.

Lindsey KA, SP Reidel, KR Fecht, JL Slate, AG Law, and AM Tallman. 1994a. "Geohydrologic setting of the Hanford Site, south-central Washington" in DA Swanson and RA Haugerud: Geologic Field Trips in the Pacific Northwest, 1994 Annual Meeting, Geological Society of America, v. 1, p. 1C-1-16.

Lindsey KA, JL Slate, GK Jaeger, KJ Swett, and RB Mercer. 1994b. Geologic setting of the low-level burial grounds. WHC-SD-EN-TI-290, Rev. 0, Westinghouse Hanford Company, Richland, Washington.

Mann FM. 1999. Scenarios for the Hanford Immobilized Low-Activity Waste (ILAW) performance assessment. Report HNF-EP-0828, R2.

Mann FM, RJ Puigh, PD Rittmann, NW Kline, JA Voogd, Y Chen, CR Eiholzer, CT Kincaid, BP McGrail, AH Lu, GF Williamson, NR Grown, and PE LaMont. 1998. Hanford immobilized lowactivity tank waste performance assessment. DOE/RL-97-69, U.S. Department of Energy, Richland Operations Office, Richland, Washington.

Meyer PD and JR Serne. 1999. Near-field hydrology data package for the Immobilized Low-Activity Waste 2001 performance assessment. PNNL-13035, Pacific Northwest National Laboratory, Richland, Washington.

Myers CW, et. al. 1979. Geologic studies of the Columbia Plateau: A status report. RHO-BWI-ST-4, Rockwell Hanford Operations, Richland, Washington.

Mitchell RM (ed.). 1998. TWRS Phase 1 privatization site preconstruction characterization report. HNF-2067, Fluor Daniel Hanford, Inc., Richland, Washington.

Reidel SP, KA Lindsey, and KR Fecht. 1992. Field trip guide to the Hanford Site. WHC-MR-0391, Westinghouse Hanford Company, Richland, Washington.

Reidel SP and KR Fecht. 1994a. Geologic map of the Richland 1:100,000 quadrangle, Washington. Open File report 94-8, Washington State Department of Natural Resources, Olympia, Washington.

Reidel SP and KR Fecht. 1994b. Geologic map of the Priest Rapids 1:100,000 quadrangle, Washington. Open File report 94-13, Washington State Department of Natural Resources, Olympia, Washington.

Reidel SP and KD Reynolds. 1998. Characterization plan for the immobilized low-activity waste borehole. PNNL-11802, Pacific Northwest National Laboratory, Richland, Washington. 
Reidel SP, DG Horton, and KD Reynolds. 1998. Immobilized low-activity waste site borehole 299-E17-21. PNNL-1 1957, Pacific Northwest National Laboratory, Richland, Washington.

Rockhold ML, MJ Fayer, and PR Heller. 1993. Physical and hydraulic properties of sediments and engineered materials associated with grouted double-shell tank waste disposal at Hanford. PNL-8813, Pacific Northwest Laboratory, Richland, Washington.

Swanson LC. 1992. Borehole completion data package for Grout Treatment Facility well 299-E25-39. WHC-SD-EN-DP-048, Westinghouse Hanford Company, Richland, Washington.

Swanson LC. 1993. Grout Treatment Facility borehole summary report for 1989 - 1993 update. WHC-SD-EN-DP-070, Westinghouse Hanford Company, Richland, Washington.

Swanson LC. 1994. 1993 borehole completion data package, Grout Treatment Facility wells 299-E25-49, 299-E25-50 and 299-E25-1000. WHC-SD-EN-DP-058, Westinghouse Hanford Company, Richland, Washington.

Swanson LC, DC Weekes, SP Luttrell, RM Mitchell, DS Landeen, AR Johnson, and RC Roos. 1988. Grout Treatment Facility environmental baseline and site characterization report. WHC-EP-0150, Westinghouse Hanford Company, Richland, Washington.

Tallman AM, KR Fecht, MC Marratt, and GV Last. 1979. Geology of the separations areas, Hanford Site, south-central Washington. RHO-ST-23, Rockwell Hanford Operations, Richland, Washington.

U.S. Department of Energy (DOE). 1988. Consultation draft site characterization plan. Reference repository location, Hanford Site, Washington. DOE/RW-0164, U.S. Department of Energy, Office of Civilian Radioactive Waste Management, Washington, D.C.

Wootan DW. 1999. Immobilized low-activity tank waste inventory data package. HNF-4921, Rev. 0, Fluor Daniel Northwest Inc., Richland, Washington. 
Appendix A

Quality Assurance and Safety 


\section{Appendix A}

\section{Quality Assurance and Safety}

All laboratory and field experiments are conducted under PNNL quality assurance (QA) requivements as described in the guidance provided in PNNL's Standards Based Management System (SBMS) and as specified in the Project QA Plan. Significant modifications to the QA plan are made in accordance with the guidance in the SBMS.

Project staff members are qualified and receive any training needed to carry out their assigned responsibilities.

Staff use equipment of known accuracy for data collection. For measurements necessary to substantiate test results, staff ensure that standards used for calibration are traceable to nationally recognized standards. Measuring and Test Equipment (M\&TE) lists are generated by each task and maintained in the project files applicable to the specific task. M\&TE used is identified in the laboratory record books or other data recording location to provide traceability to instrument calibrations.

Test procedures and methods are documented and deviations noted. New methods developed during the course of this work are documented and reviewed. All test procedures, data processing software, and supporting documentation undergo independent technical review by qualified PNNL staff.

Staff maintain records necessary to substantiate results and processes of research activities. After activities are completed, records are filed and maintained per the project Records Inventory and Disposition Schedule (RIDS).

All precautionary measures are taken in accordance with standard PNNL safety procedures to ensure that field work is conducted in a safe manner. No hazardous wastes have been generated during the conduct of work described in this report. 


\section{Appendix B}

\section{Paleomagnetic Study}




\title{
Paleomagnetism of Borehole 299-E17-21 Sediments, Hanford, WA
}

\author{
prepared by Christopher J. Pluhar \\ under the supervision of Professor Robert S. Coe
}

University of California, Santa Cruz

Earth Sciences Dept.

1156 High St.

Santa Cruz, CA 95064-1077 


\section{Abstract}

We have completed paleomagnetic analysis of seventeen sediment samples of the Hanford Formation from a drill core recovered from borehole 299-E17-21 at the Hanford DOE site. These analyses reveal dominantly reversed polarity directions, including that these sediments are older than the Brunhes-Matuyama magnetic reversal (780 ka).

\section{Introduction}

Seventeen minimally-consolidated, oriented samples were collected from the most finegrained segments of the drill core (Table 1). The samples consisted of cubes "carved" from the drill core. Plastic sample boxes were placed over/around each cube before it was detached from the core. Sample lithology varied between fine and coarse grained sand, but in all cases was very loose and therefore likely sustained some randomization from shaking in transit from Washington to Santa Cruz. Upon arrival, samples were cemented with sodium silicate solution and in some cases were capped with alumina cement to prevent the loss of sample. Samples were analyzed in a 3-axis DC SQUID cryogenic magnetometer, housed in a shielded room at the UC Santa Cruz paleomagnetism lab.

\section{Demagnetization Experiments}

We conducted unusually detailed alternating field (AF) demagnetization experiments on the samples to reveal their characteristic remanent magnetization (ChRM) directions. Typical AF demag steps were; NRM, 1, 2, 3, 4, 5, 6, 7, 8, 10, 13, 16, 20, 25, 30, 35, 40,.. milli-Tesla (mT). Demagnetization was considered complete when the remaining sample magnetization intensity was $<10 \%$ of NRM, or more than 3 consecutive directions along a sample's demag path were highly scattered and non-collinear. Typically, samples dropped below $50 \%$ of their NRM intensity before the $10 \mathrm{mT}$ AF step and the ChRM is at least partially revealed by $10 \mathrm{mT}$. This indicates low coercivity magnetization of the samples, leading to concern about the samples being overprinted in situ, or during drilling, transportation and storage. None of the rigorous paleomagnetic tests for sample overprinting (reversal test, fold test, conglomerate test) are available to us due to the nature of the samples (derived from one drill core and apparently containing no magnetic reversals). However, any in situ overprinting with a reversed-polarity direction would require that the samples existed during a reversed chron of significant length, still making them $>780 \mathrm{ka}$. Furthermore, the observed ChRM is of similar inclination to that expected for the Hanford geographic area. Overprinting during drilling could have induced a uniform overprint, but since the observed ChRM is not parallel to the drill string (inclination direction \pm 90 ), it is unlikely caused by drilling. Overprinting by the earth's field during sample storage is possible, if the core segments were all stored parallel, and with their tops all toward the same direction. However, to produce the observed ChRM the cores would have to be stored flat side down with the core tops pointing in a northerly direction. This is not the case. The cores were stored flat side up and therefore overprinting during storage is unlikely unless the storage location possesses a uniform ambient field opposed to the earth's field.

Thermal demagnetization experiments were not conducted since the samples were extremely friable and contained in plastic sample boxes. It is very possible that thermal demag would yield superior results if samples could be cemented prior to removal from the drill core.

\section{Least-squares Sample Analysis}

We obtained the ChRM directions by fitting least-squares lines to the demagnetization data (see Zijderveld diagrams on the following pages). Typically, higher level demag segments of the demagnetization paths degenerated to highly-scattered, semi-random collections of points. Thus points chosen for least-squares fitting are at relatively low demag levels, although generally we 
Table 1 - Borehole 299-E17-21 Stratigraphic, Lithologic and Paleomagnetic Summary

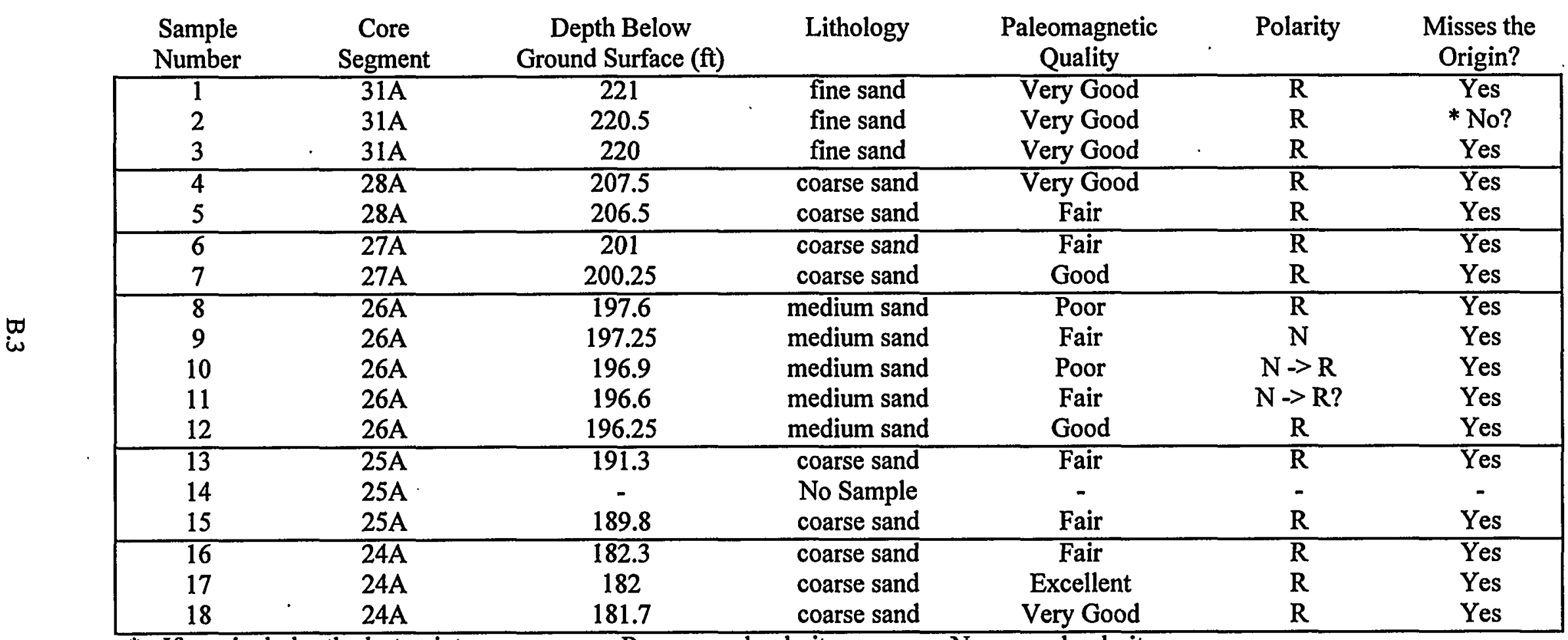

\footnotetext{
* - If one includes the last point $\quad \mathrm{R}$ - reversed polarity $\mathrm{N}$ - normal polarity
} 

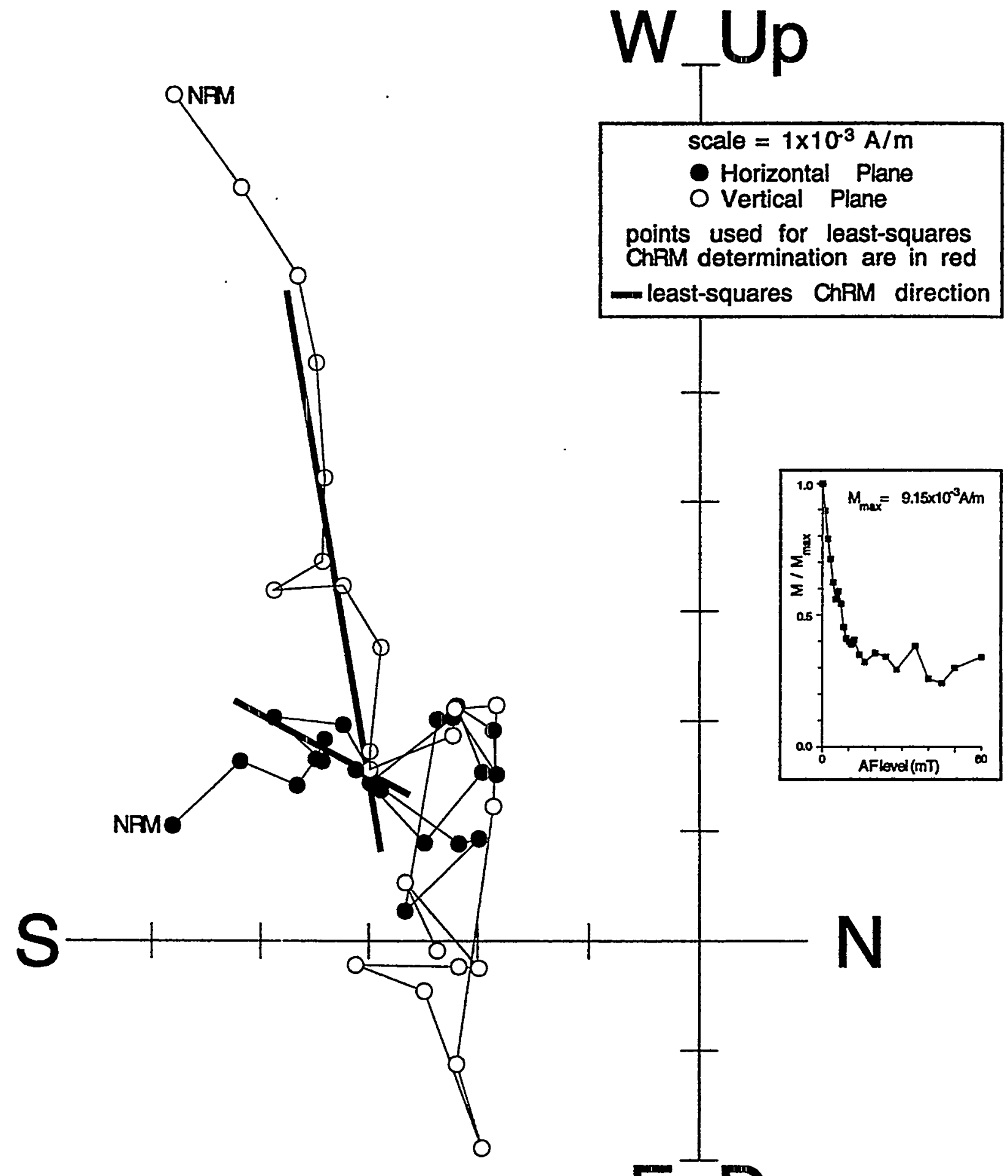

Sample 1 (from Core 31A) 


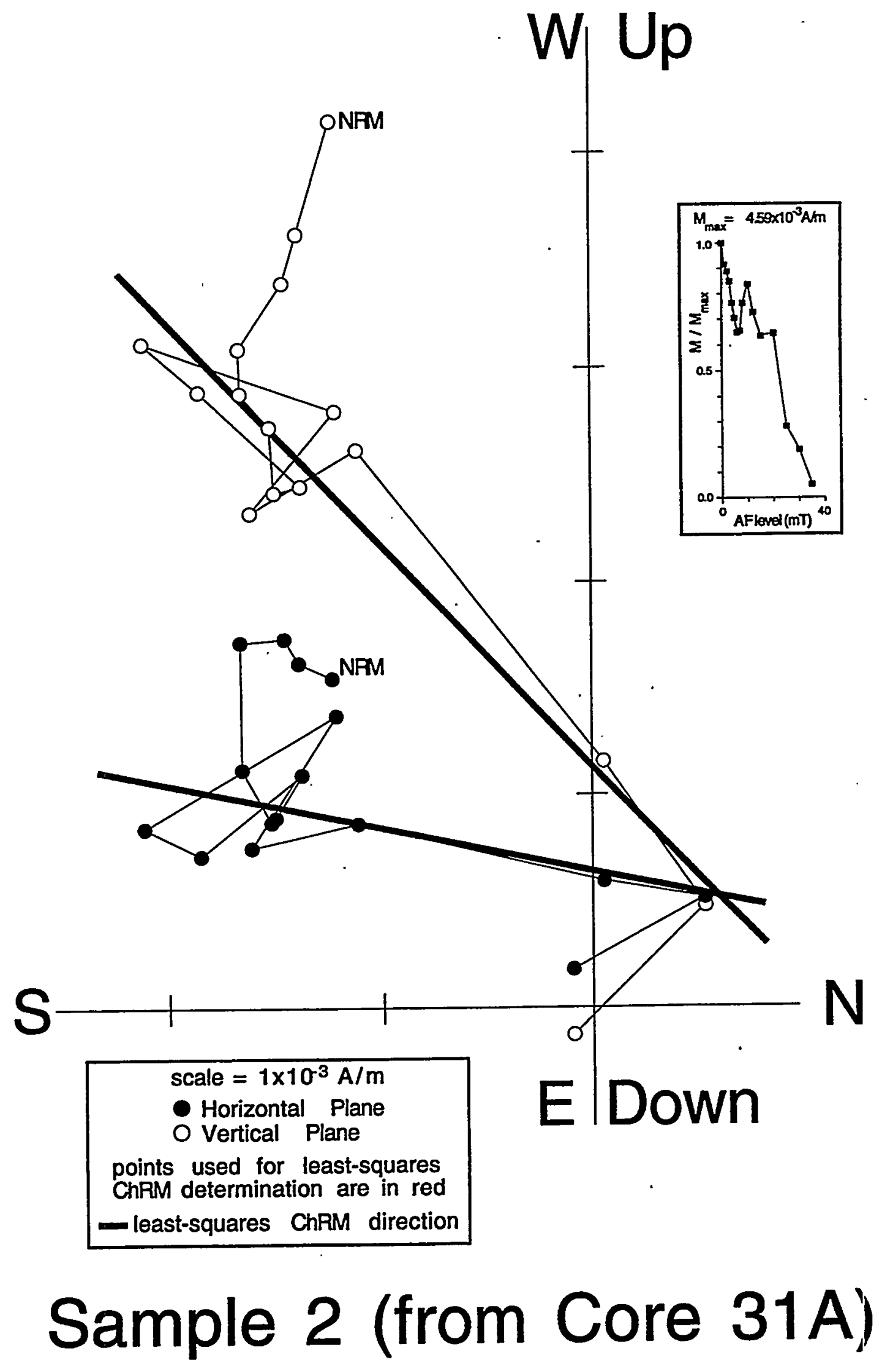

B. 5 


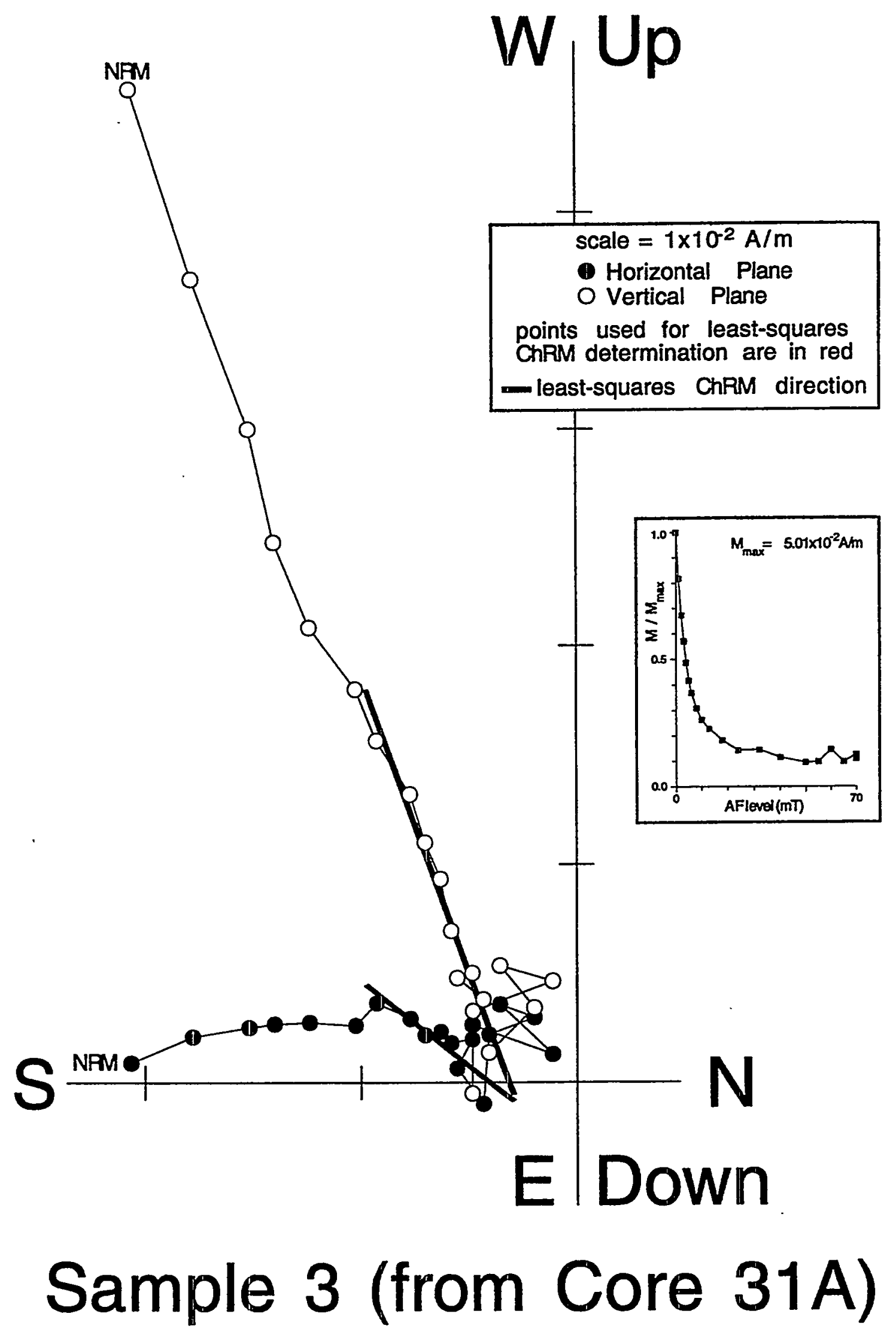

B. 6 


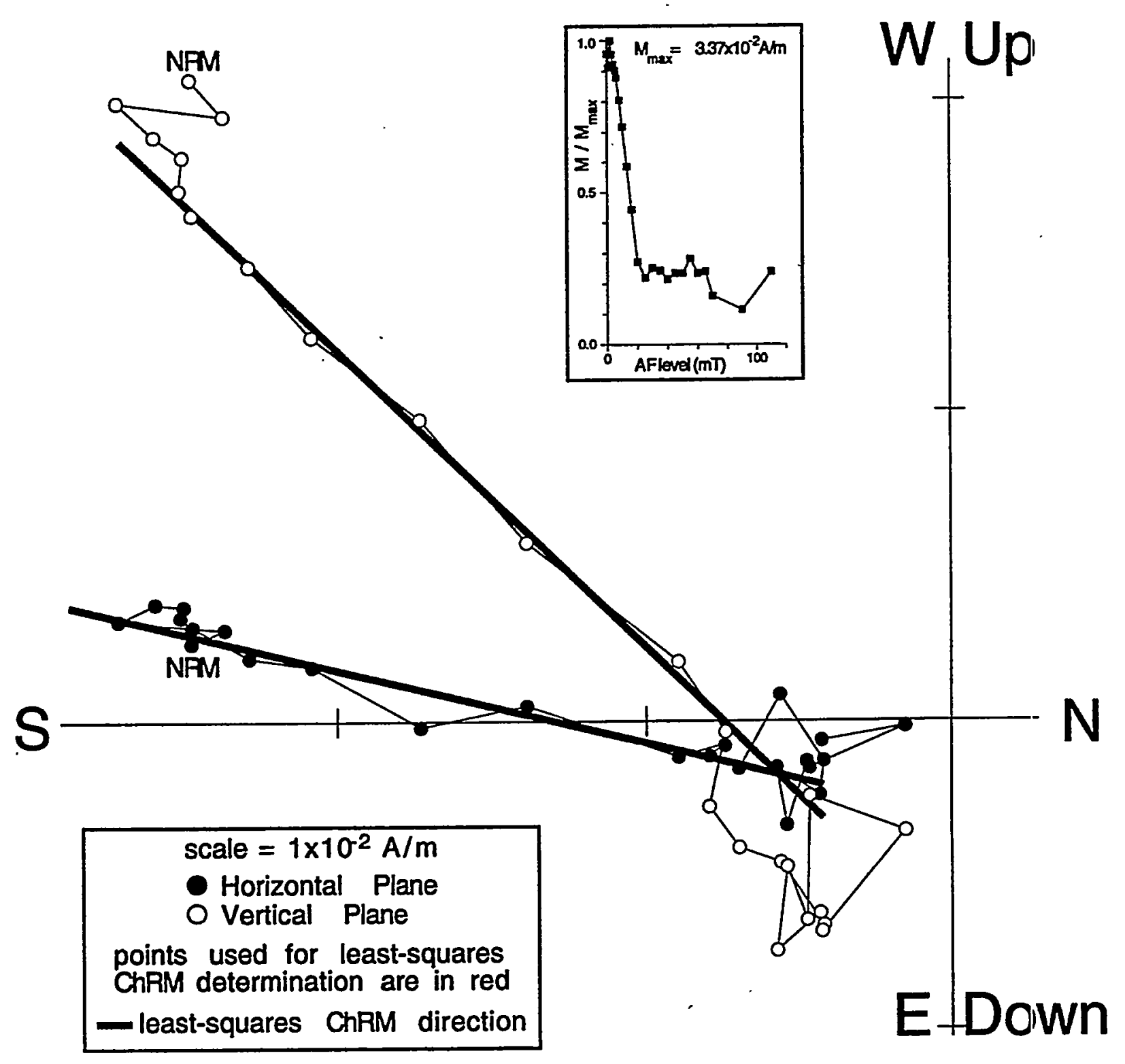

\section{Sample 4 (from Core 28A)}

B.7 


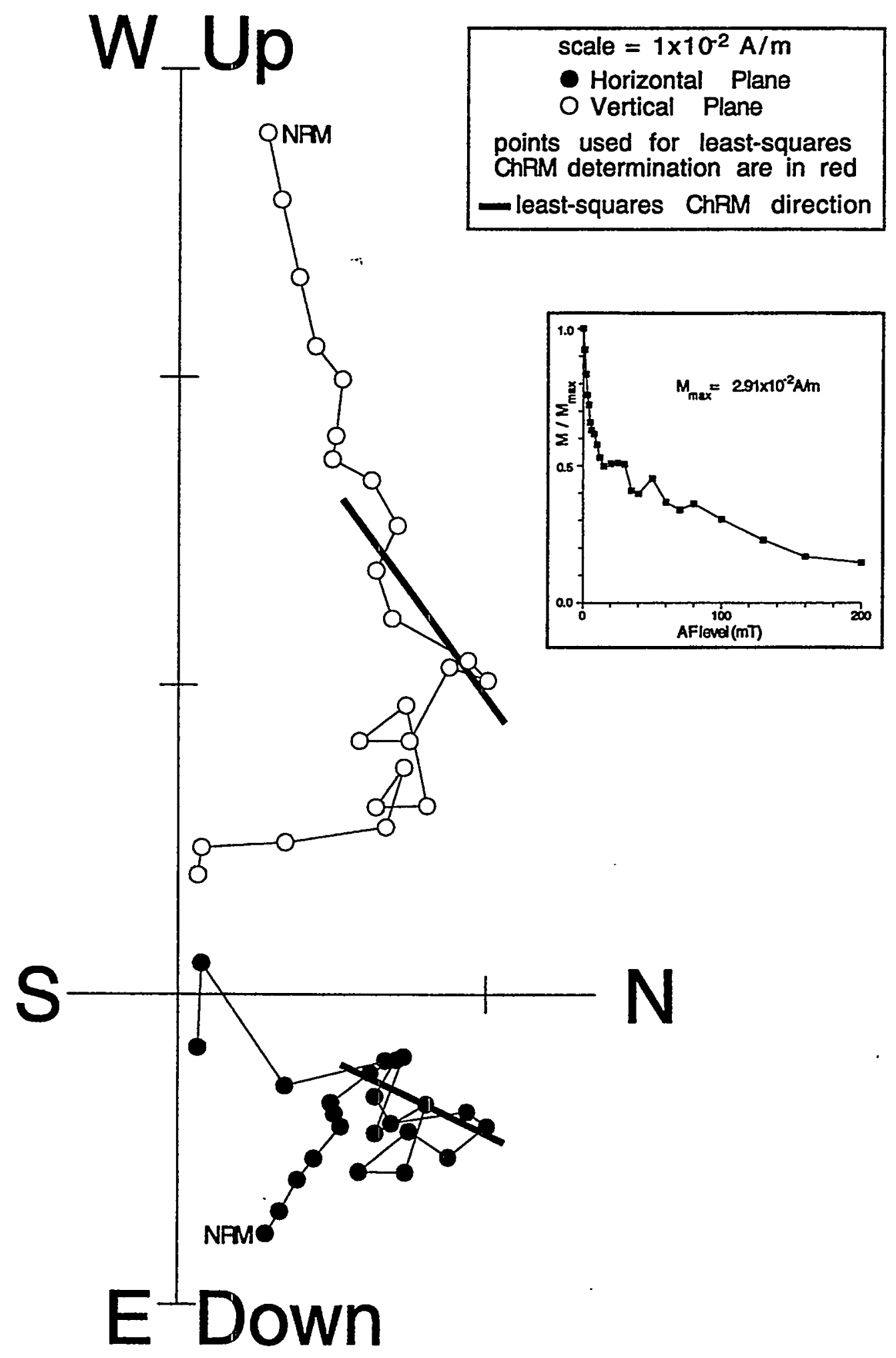

Sample 5 (from Core 28A) 


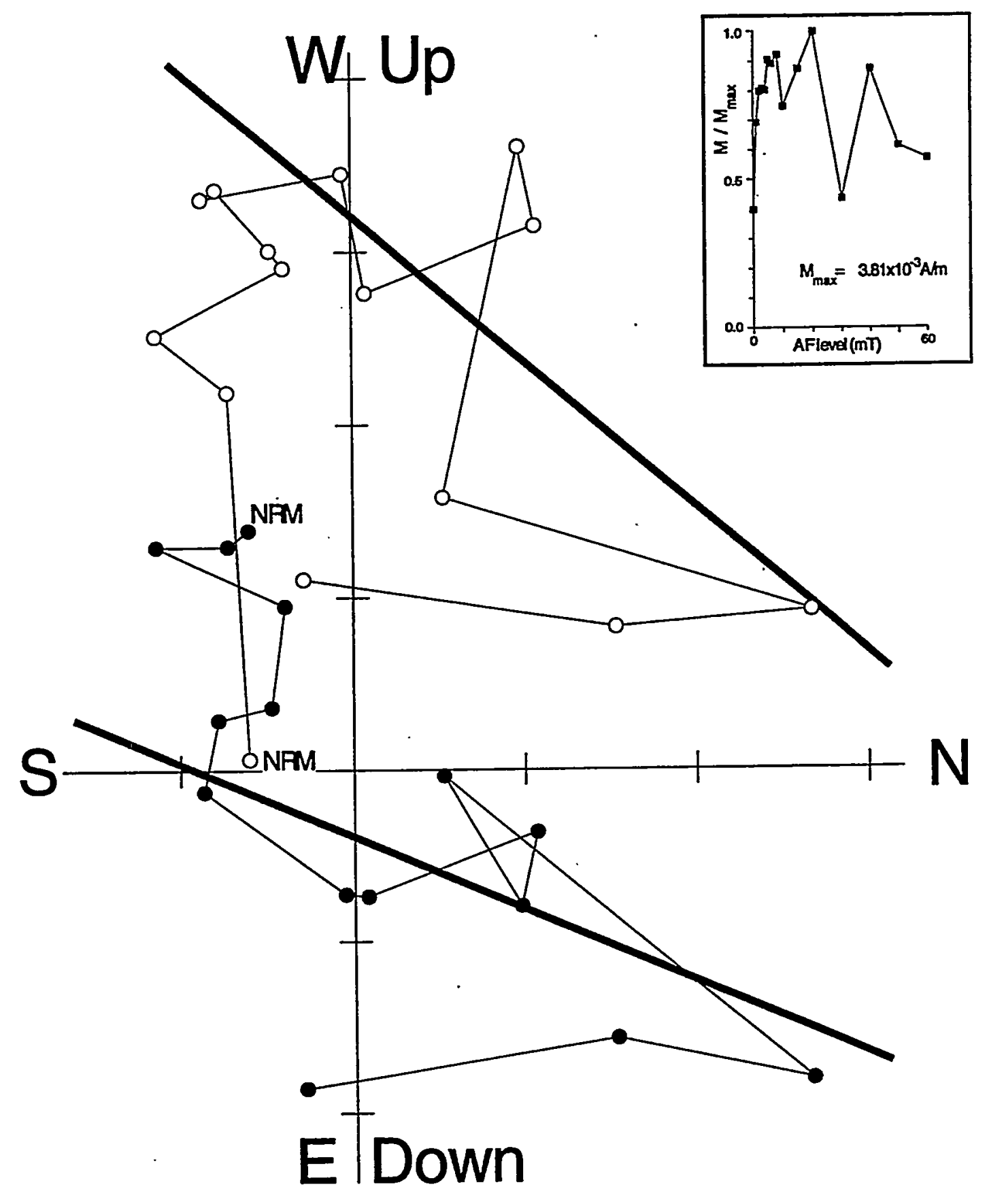

scale $=1 \times 10^{-3} \mathrm{~A} / \mathrm{m}$

- Horizontal Plane

O Vertical Plane

points used for least-squares

ChRM determination are in red

- least-squares ChRM direction

\section{Sample 6 (from Core 27A)}




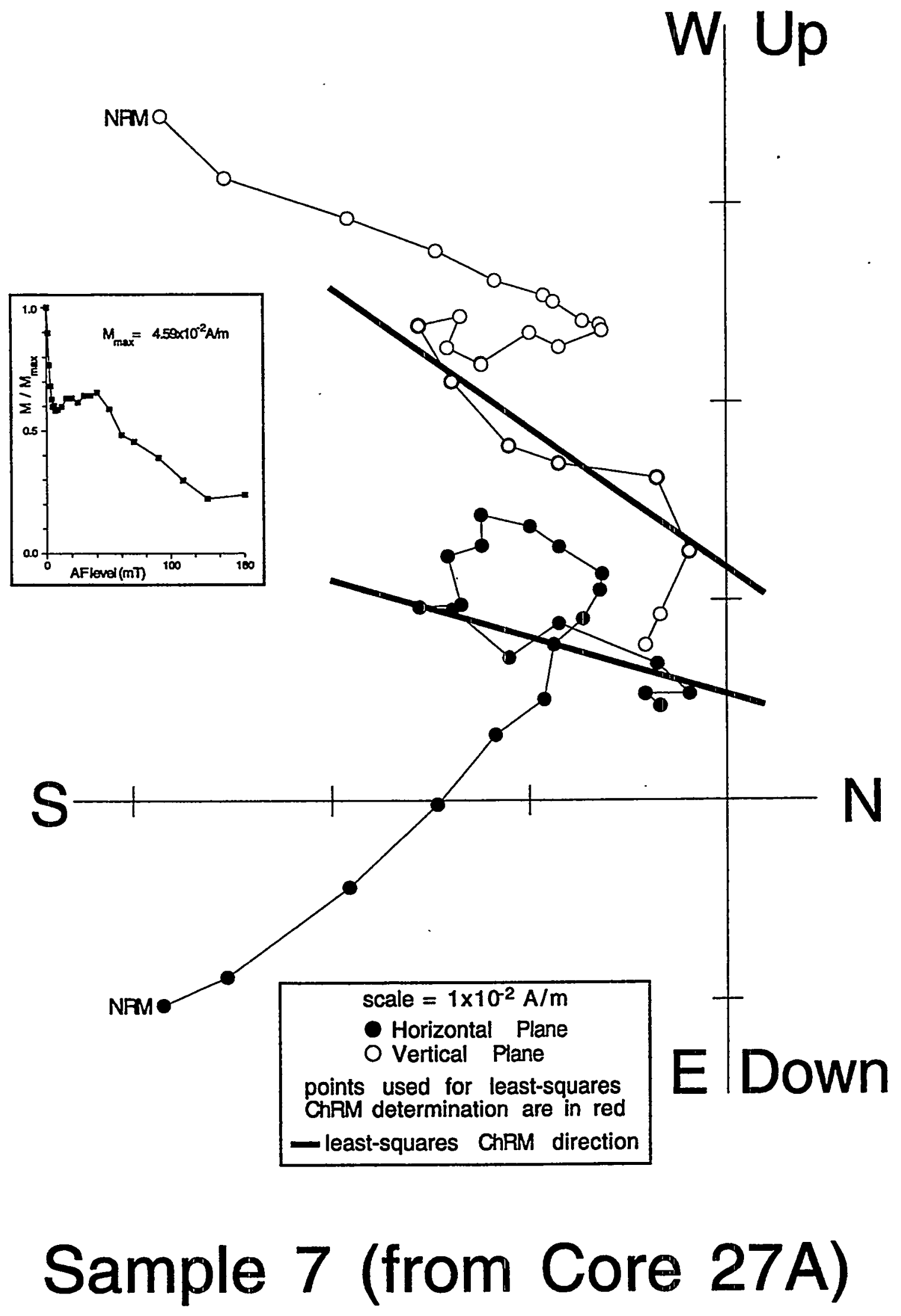

B. 10 


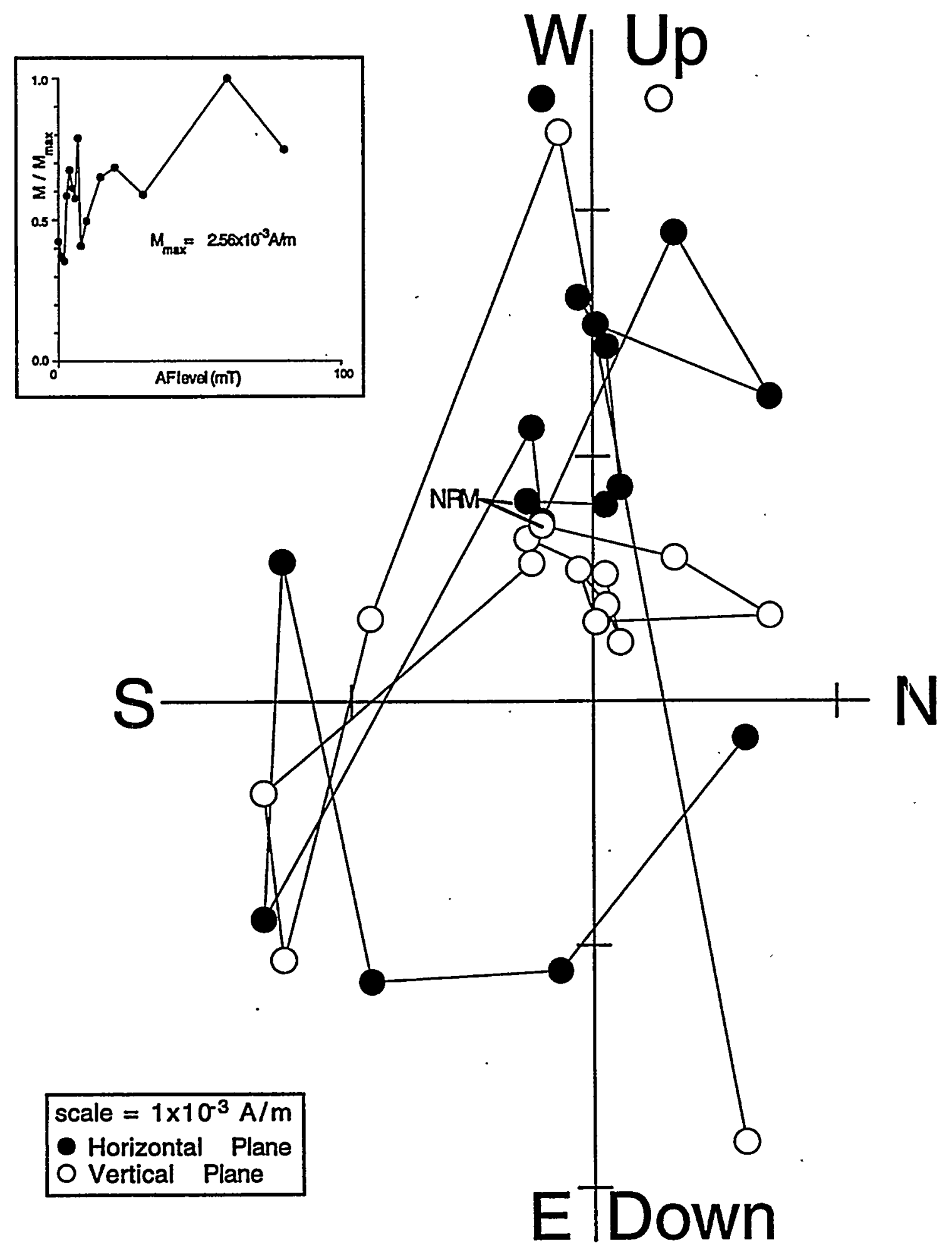

Sample 8 (from Core 26A) 


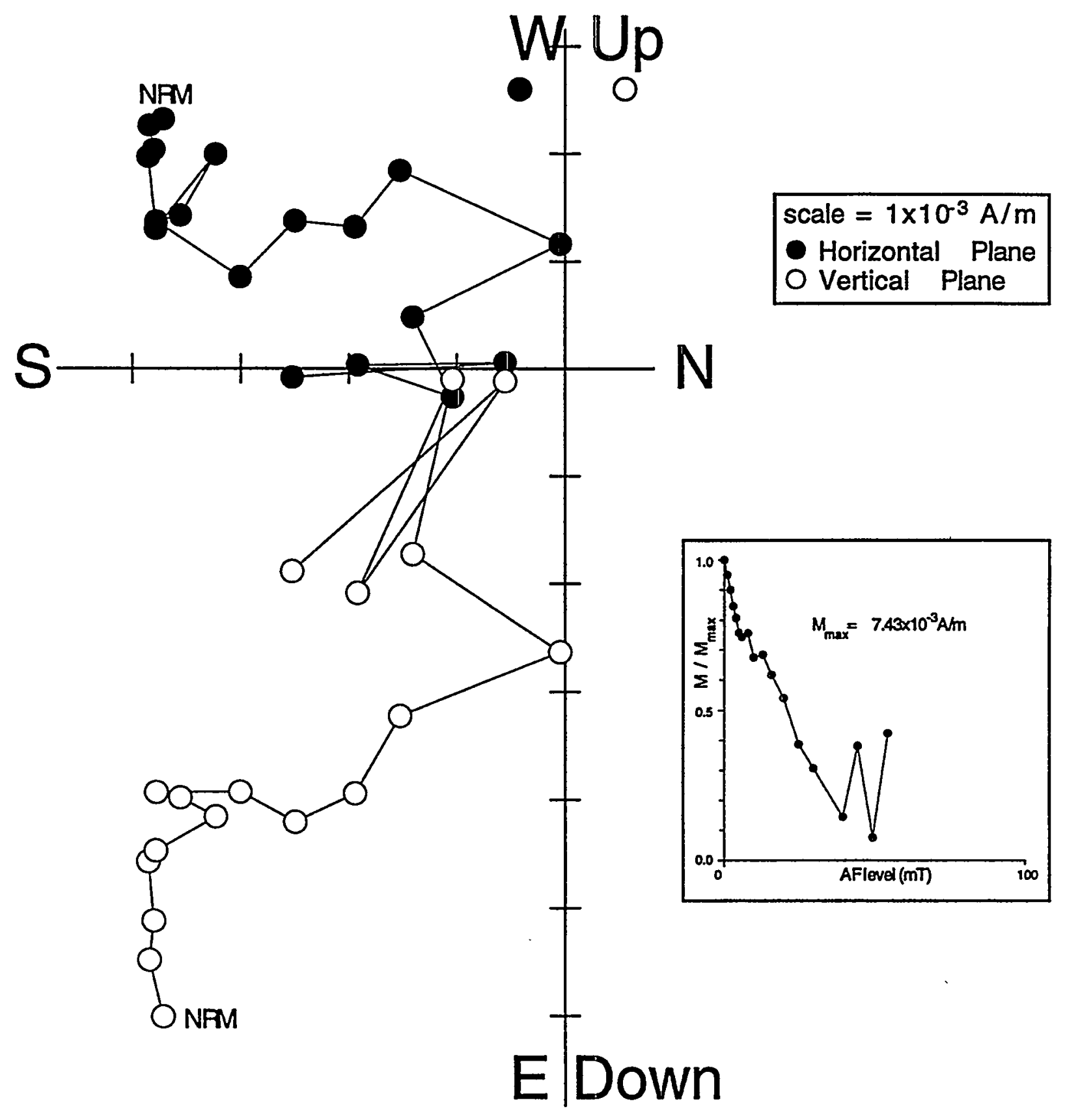

Sample 9 (from Core 26A) 


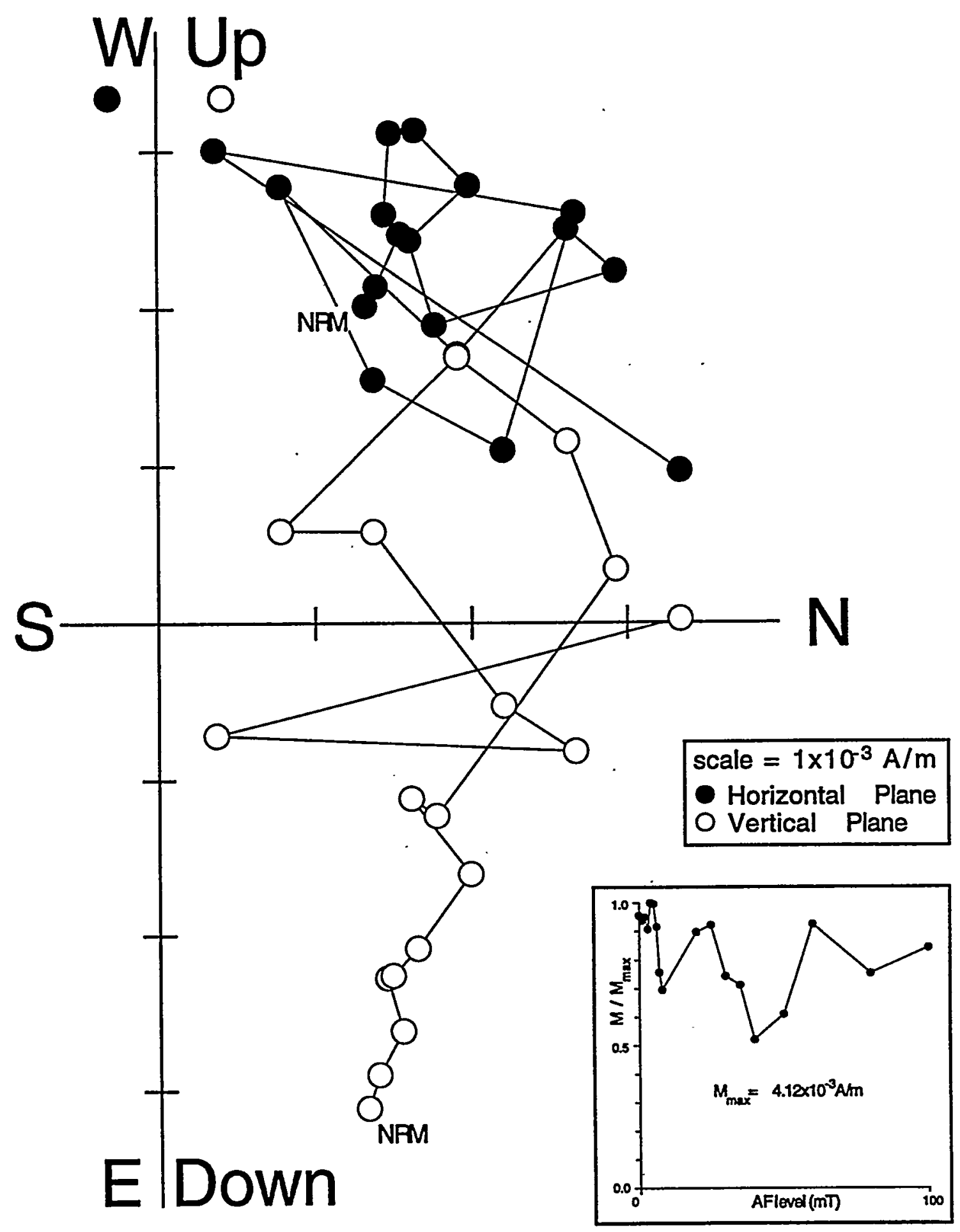

Sample 10 (from Core 26A) 


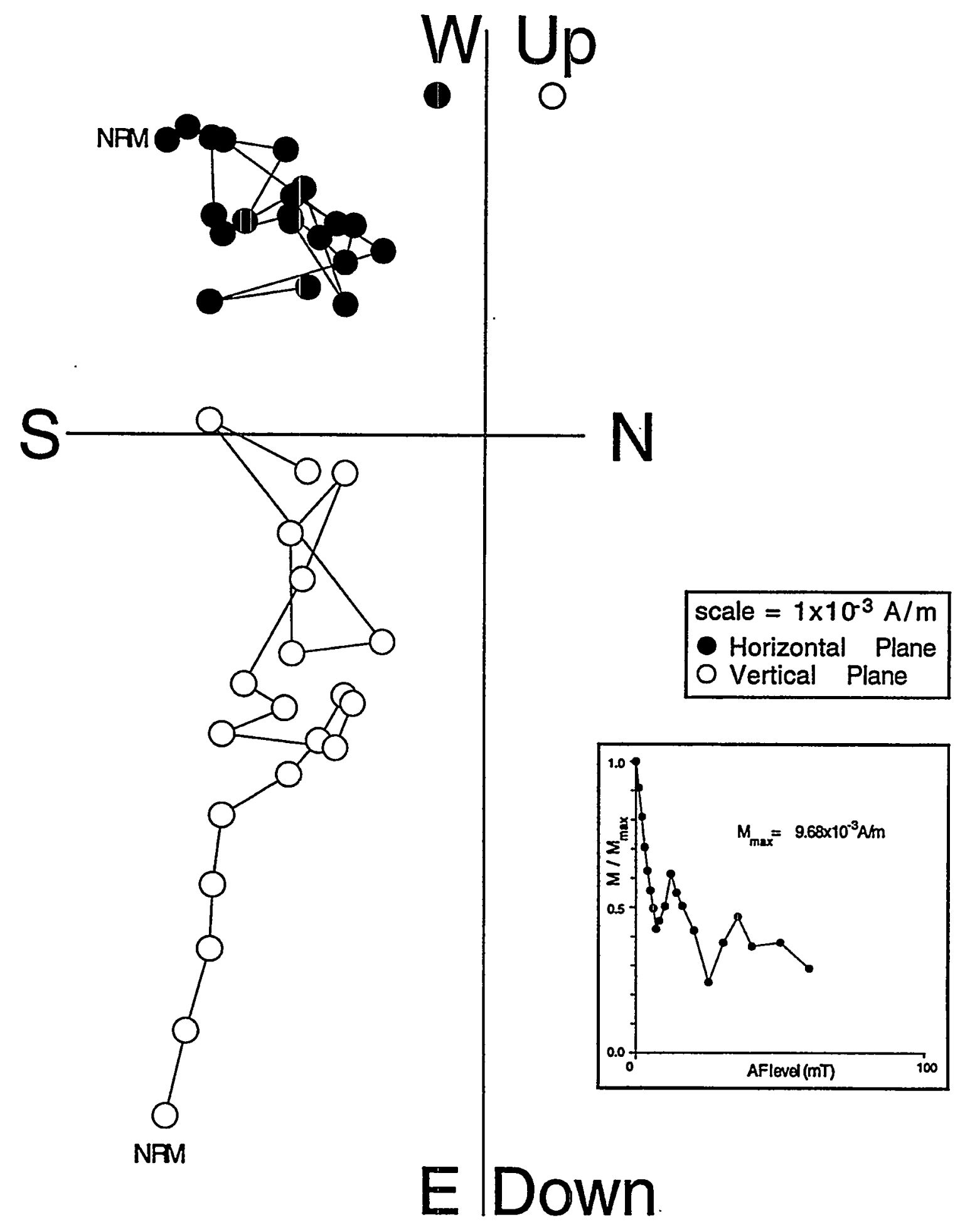

Sample 11 (from Core 26A) 


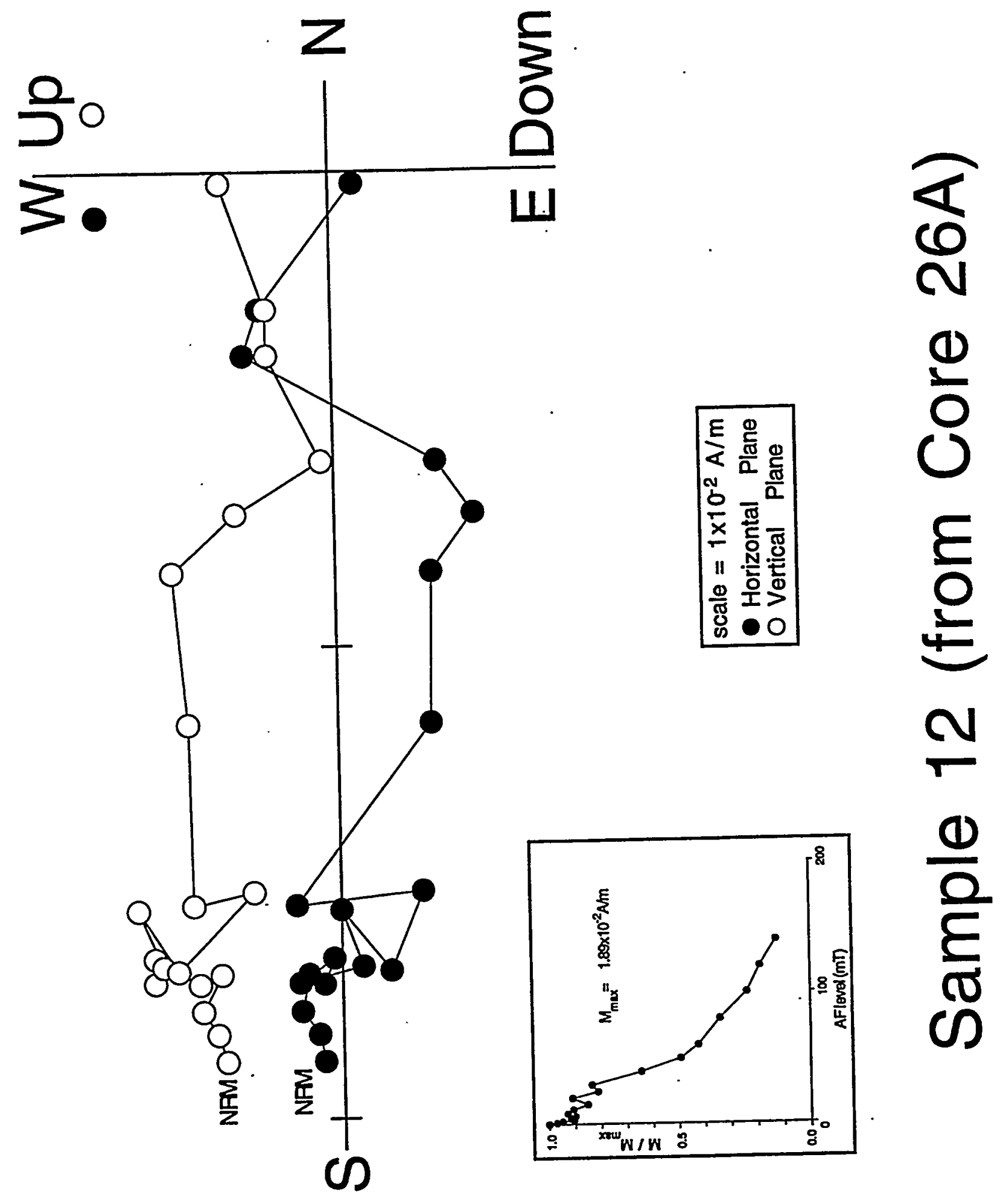



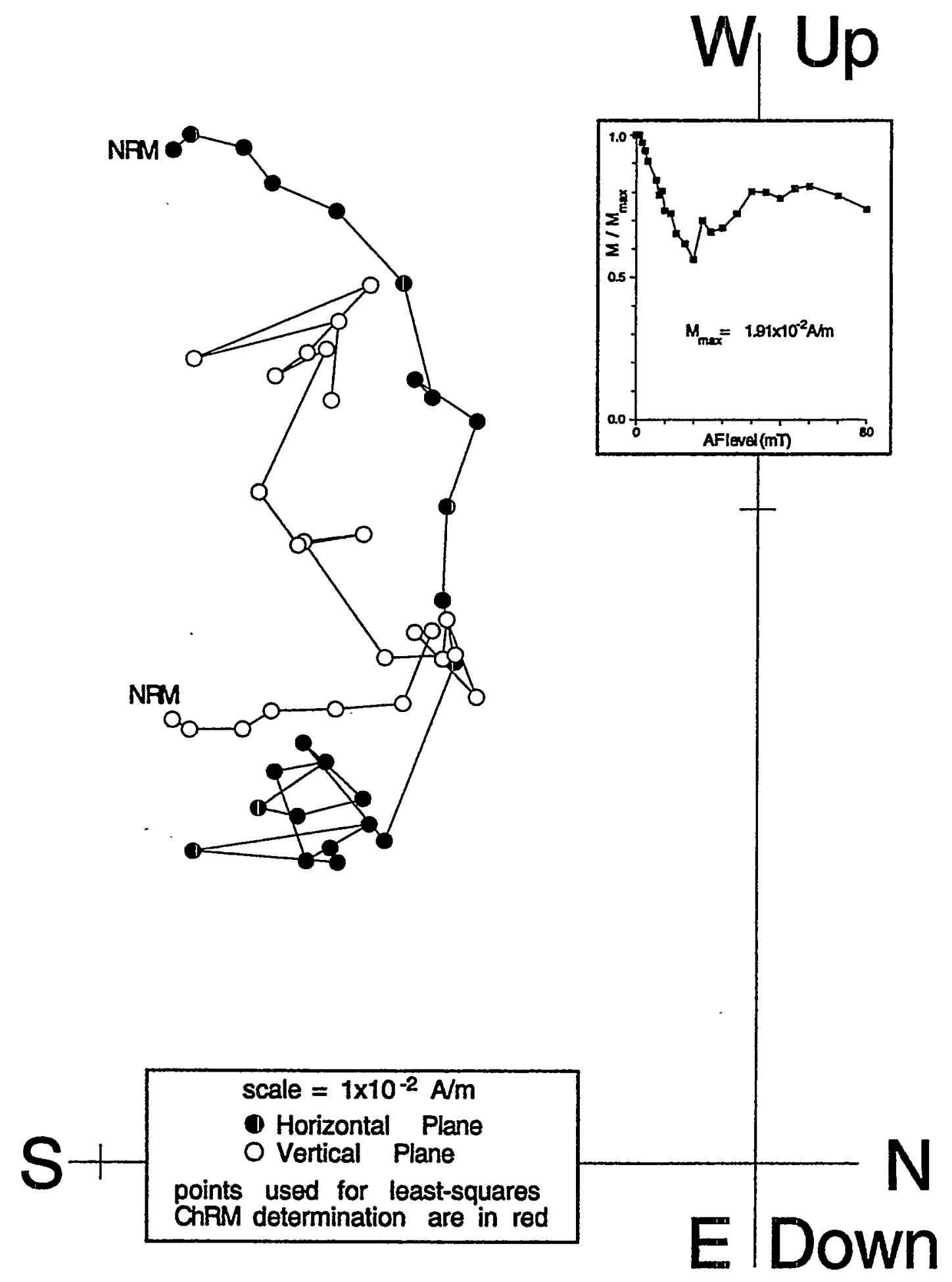

\section{Sample 13 (from Core 25A)}




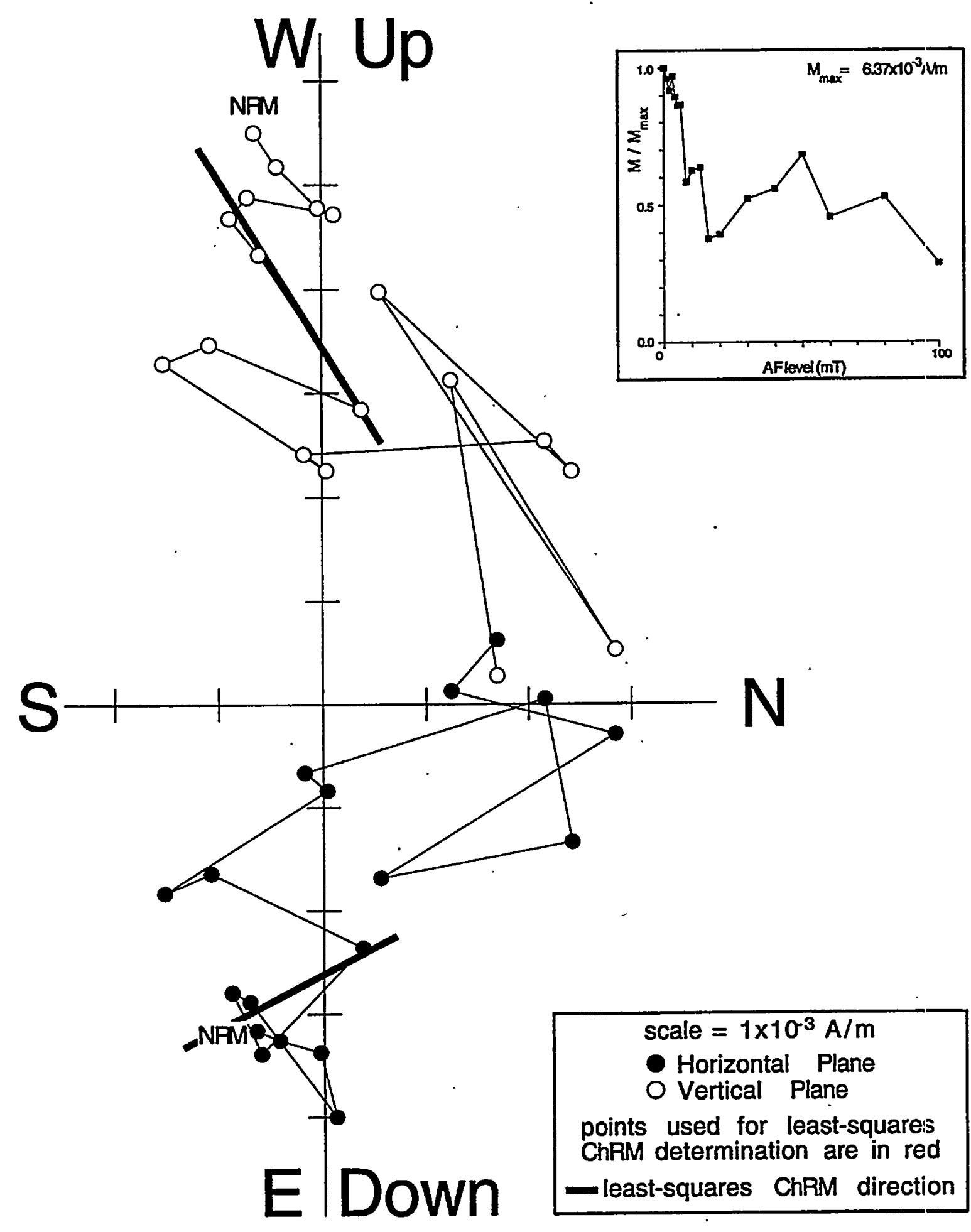

Sample 15 (from Core 25A)

B.17 


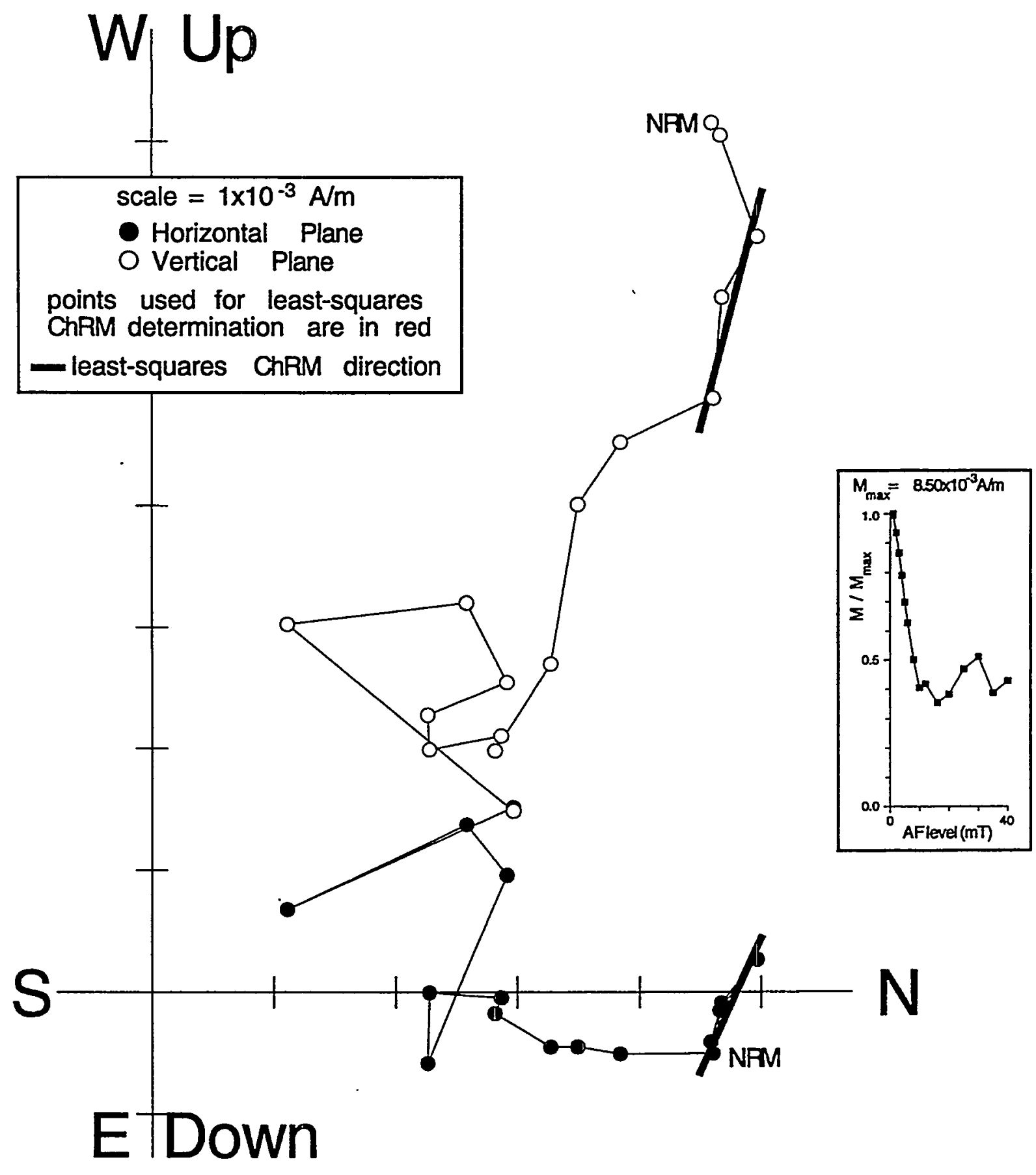

Sample 16 (from Core 24A)

B.18 

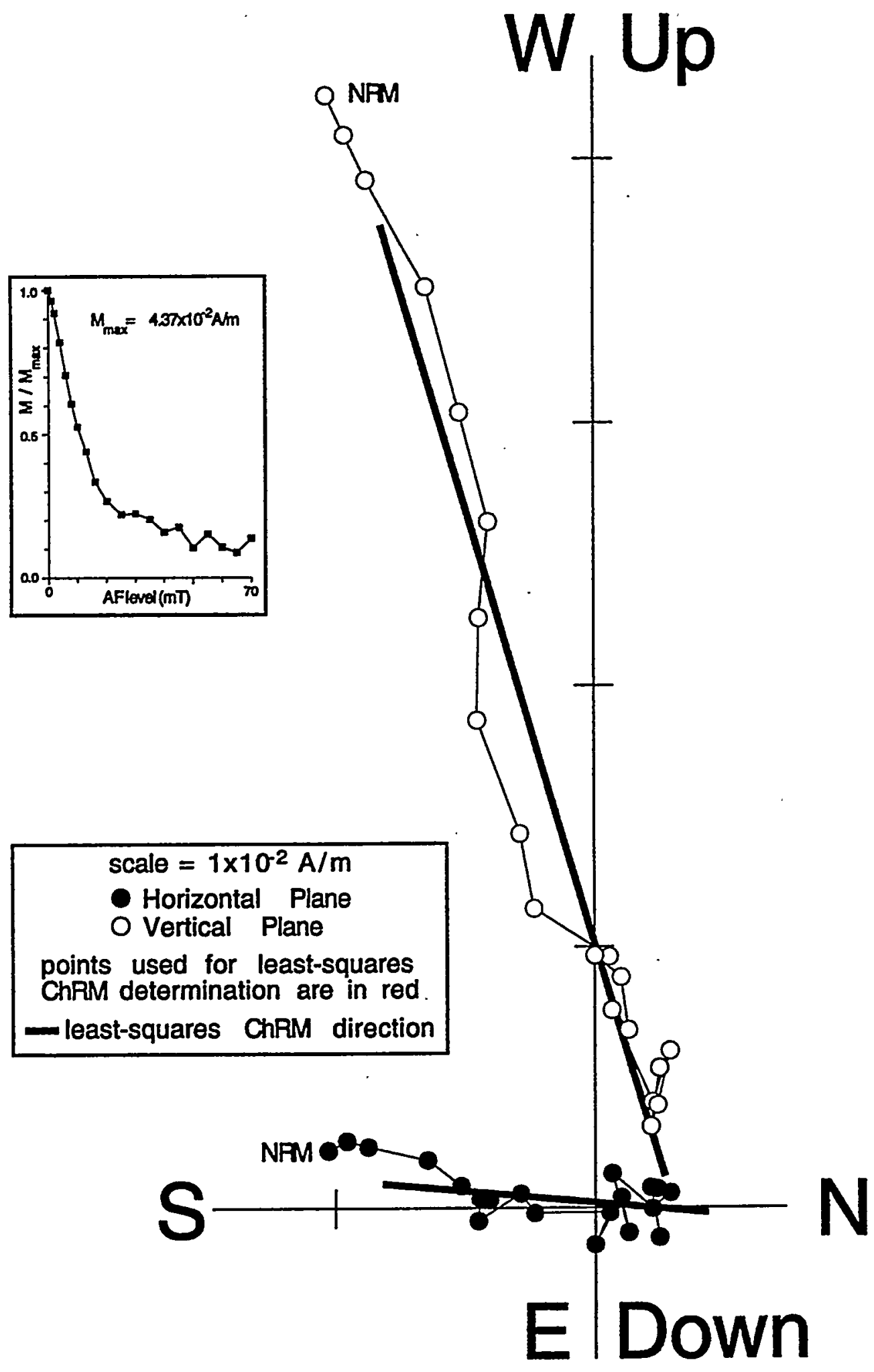

Sample 17 (from Core 24A)

B.19 


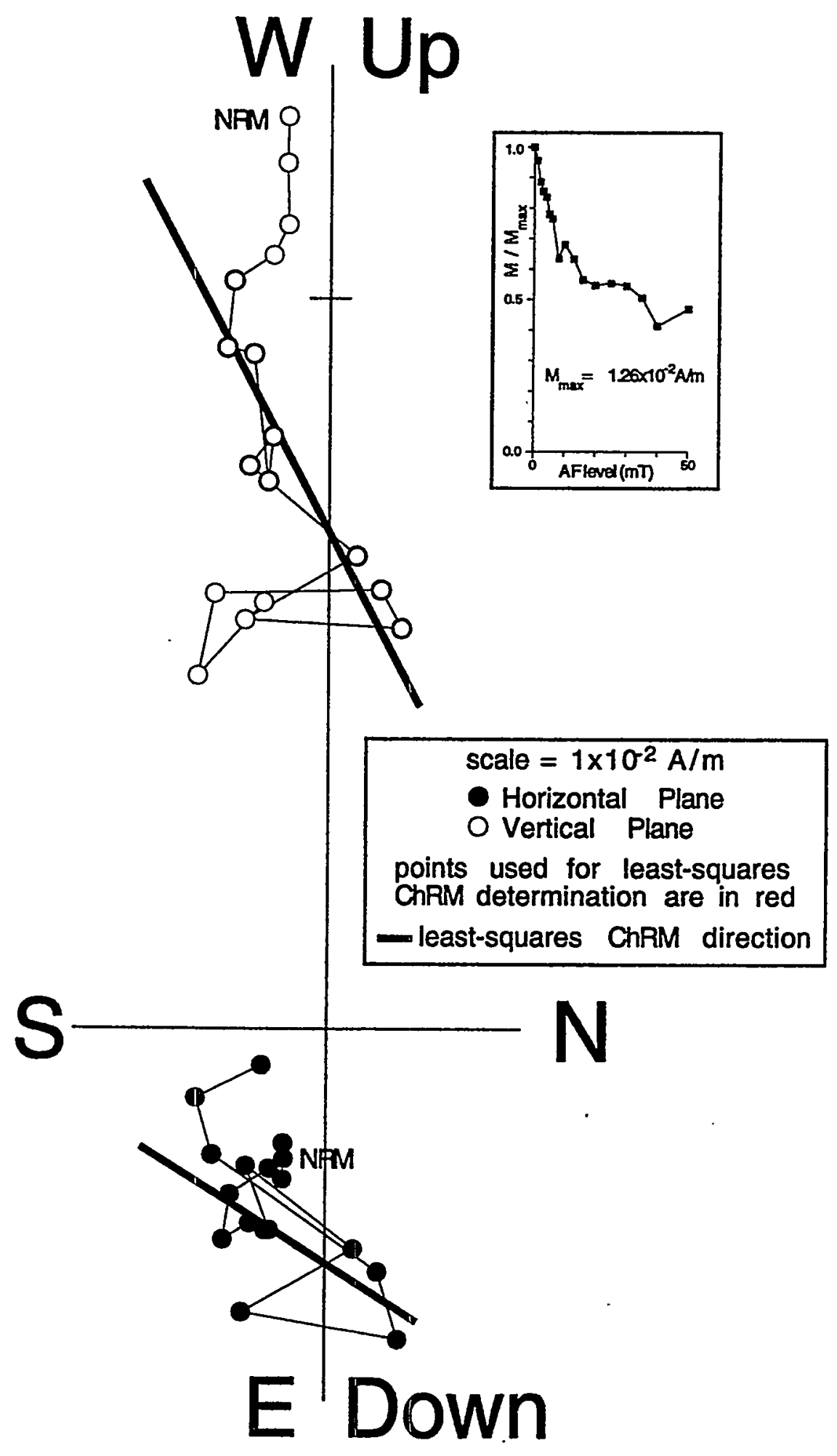

\section{Sample 18 (from Core 24A)}


magnetic overprints. While least-squares analysis of some points is rather questionable, all such ChRM directions were chosen because of favorable agreement with samples derived from the same drill-core segment, creating the most plausible magnetostratigraphy.

Least-squares analysis was not performed on core segment $26 \mathrm{~A}$ because of the highly scattered nature of the data and lack of a consistent ChRM for the core segment. Either magnetic overprint or physical disruption has degenerated the paleomagnetic quality of these samples. However, it is noteworthy that these samples nonetheless possess an upward inclination or the demag path heads towards an upwards inclination. We therefore interpret this core segment to be of reversed polarity.

Lithology only somewhat controls the quality of individual sample results. Samples 1-3 are the finest-grained and yield some of the best results (Table 1). However, samples 8-12 are the nextfinest-grained and yield the poorest results, with very coarse-grained samples 4-7 and 13-18 yielding fair to good results.

\section{Magnetostratigraphy}

The figure on the next page shows the ChRMs of each core segment in equal area stereographic projection. Presumably, within each core segment there has been a minimum of disruption from drilling and therefore the ChRMs from each segment will be oriented consistently relative to each other. As one can see, this is plausibly true - each cluster of directions only ciccupies approximately one quadrant. The ChRM inclination is essentially that expected for the gecigraphic latitude of the drilling site during a reversed-polarity chron. Note that only core 26A fails to provide well-grouped, easily-interpreted directions. We believe this results from disruption of the core while drilling, rather than the samples indicating some normal polarity chron.

Orientation between core segments should be random, as we understand it, due to the method of core retrieval. However, this appears not to be the case, resurrecting the possibility that the ChRM is some sort of uniformly-induced overprint like that which might be acquired from earth's field applied to a neatly stored drill core.

\section{Observations}

1. All but three samples have reversed polarity (i.e., upward) remanent magnetizations.

2. Of the three normal polarity samples, the demagnetization paths of two appear headed towards reversed polarity.

3. Essentially the demagnetization paths of all seventeen samples miss the origin.

\section{Interpretations}

1. The samples we have analyzed were magnetized mainly in a reversed polarity magnetic field, and was probably also deposited in a reversed field. Therefore, the age of these sediments is greater than $780 \mathrm{ka}$.

2. Only 5 of the seventeen samples have a low-coercivity normal-polarity overprint (samples 6,9 , $10,11,13)$.

3. Some samples appear to have a small, high-coercivity normal overprint, possibly resulting from the mineral geothite. While almost all samples become unstable at the higher AF levels, and therefore fail to decay smoothly to the origin.

\section{Conclusions}

Despite the lack of consolidation, paucity of fine-grained material, and non-ideal demagnetization behavior, the reversed paleomagnetic signal strongly suggests that this core is older than $780 \mathrm{ka}$. Either it is a primary magnetization acquired at or shortly after deposition (our preferred interpretation) or it is a secondary overprint. In either case it was acquired in a reversed polarity chron, the youngest known of which ended $780 \mathrm{ka}$ ago. 

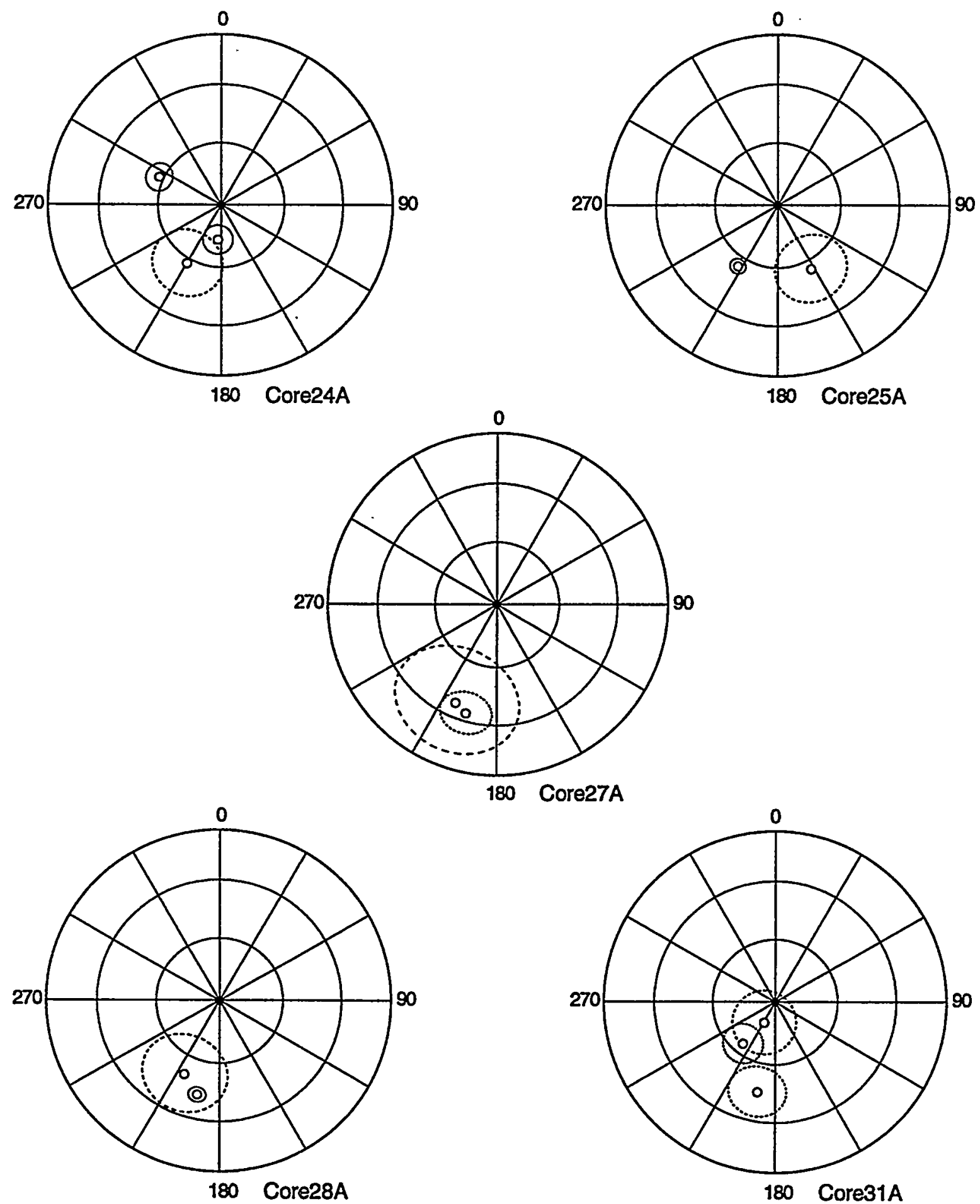

Sample Characteristic Remanent Magnetization Directions Presented in equal-area stereographic projections and plotted separately for each core segment, except Core 26A which did not yield ChRMs (see text). Open circles signify projection onto the upper-hemisphere, and each direction is accompanied by an alpha 95 . 


\section{Appendix C}

Summary Stratigraphic Cross Sections for the Existing and New Immobilized Low-Activity Waste Disposal Sites 


\section{Appendix C}

\section{Summary Stratigraphic Cross Sections for the Existing and New Immobilized Low-Activity Waste Disposal Sites}

This appendix provides summary diagrams showing cross sections for the existing and new Irnmobilized Low-Activity Waste (ILAW) disposal sites based on the more detailed geology presented in Section 4.0. Figures C.1, C.2, and C.3 are for the existing ILAW disposal site. Figures C:4, C.5, and C.6 are for the new ILAW disposal site. These figures were constructed to show the principal features; of both sites for use in the ILAW Performance Assessment. Thin, local layers or layers with uncertain extent that depicted in the cross sections in Section 4.0 were omitted. Clastic dikes are not shown because their locations are not known even though they are suspected of being present.

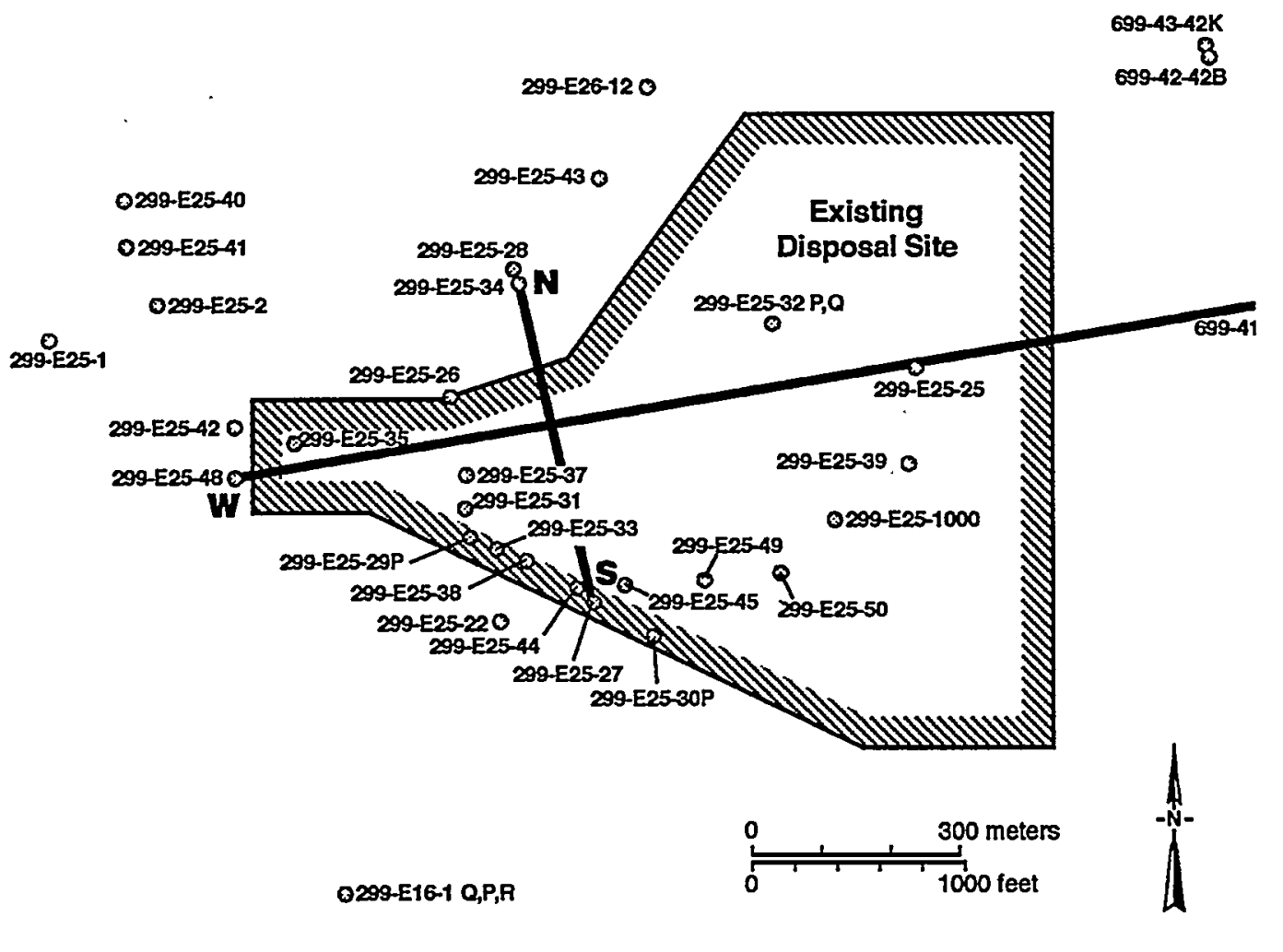

G99110108.2

Figure C.1. Map of the Existing ILAW Disposal Site Showing the Locations of the Summary Cross Sections 


\section{West}

\section{East}

\section{Existing Disposal Site}

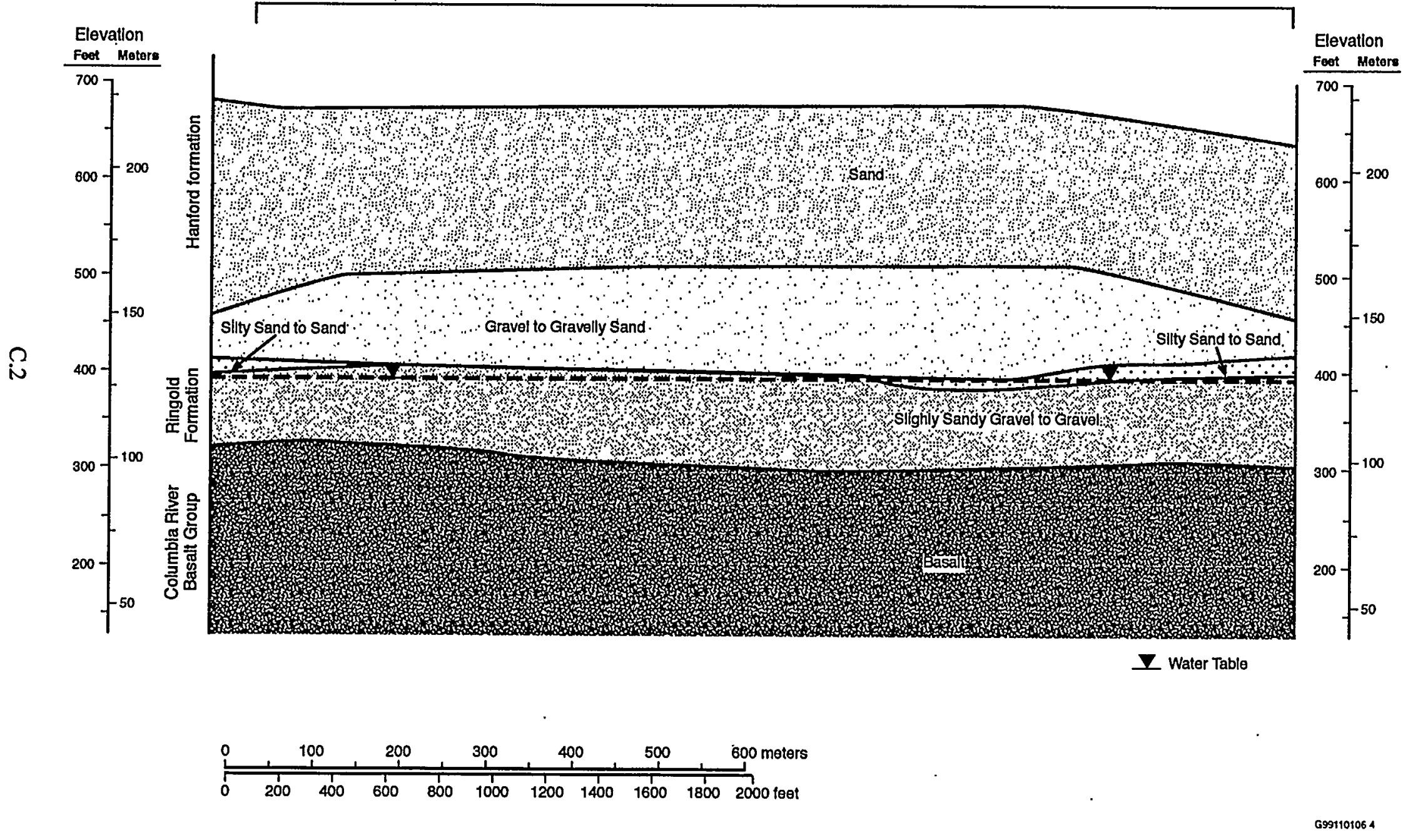

Figure C.2. Summary Diagram of a West to East Cross Section for the Existing ILAW Disposal Site 

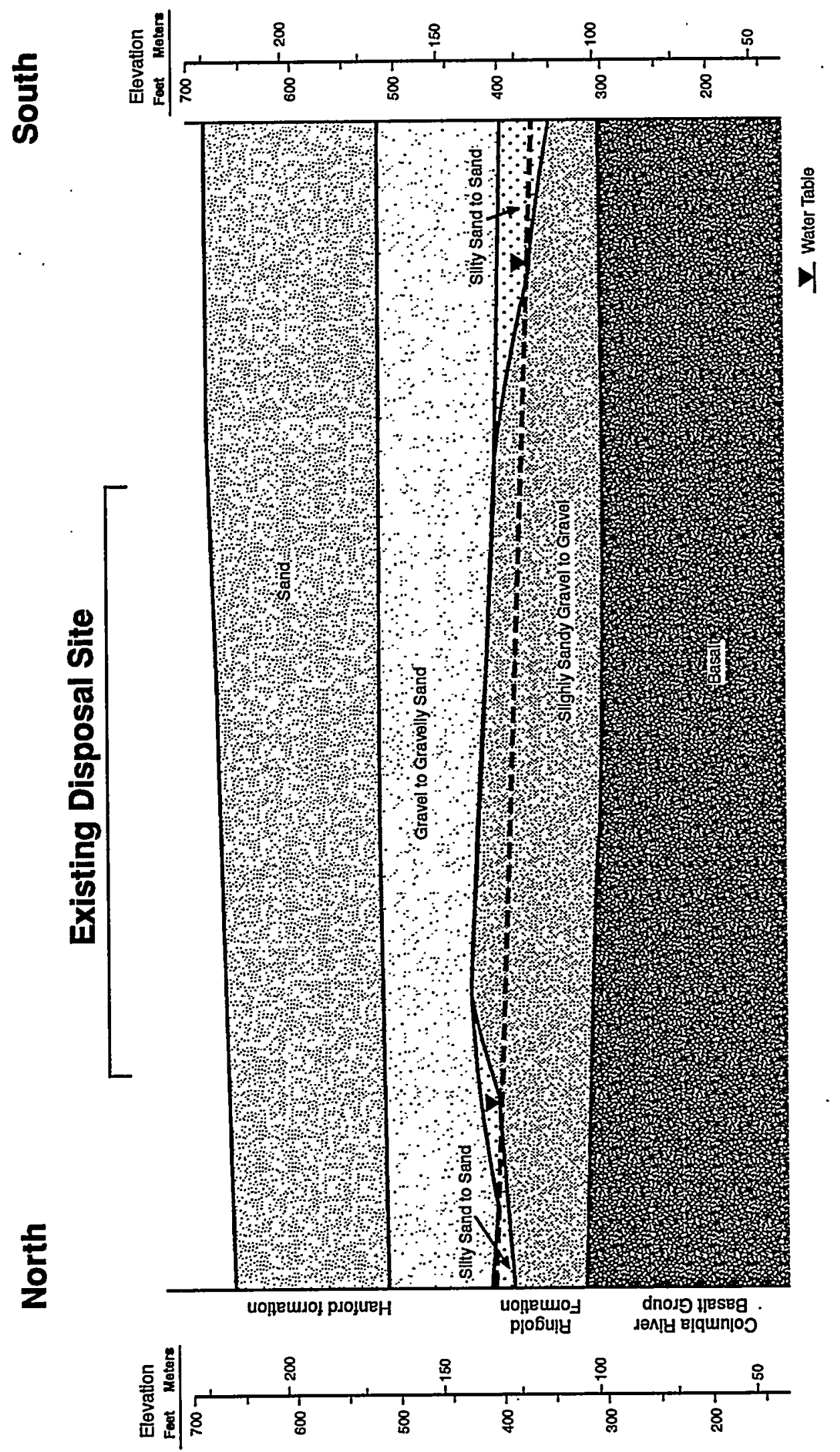

C.3 

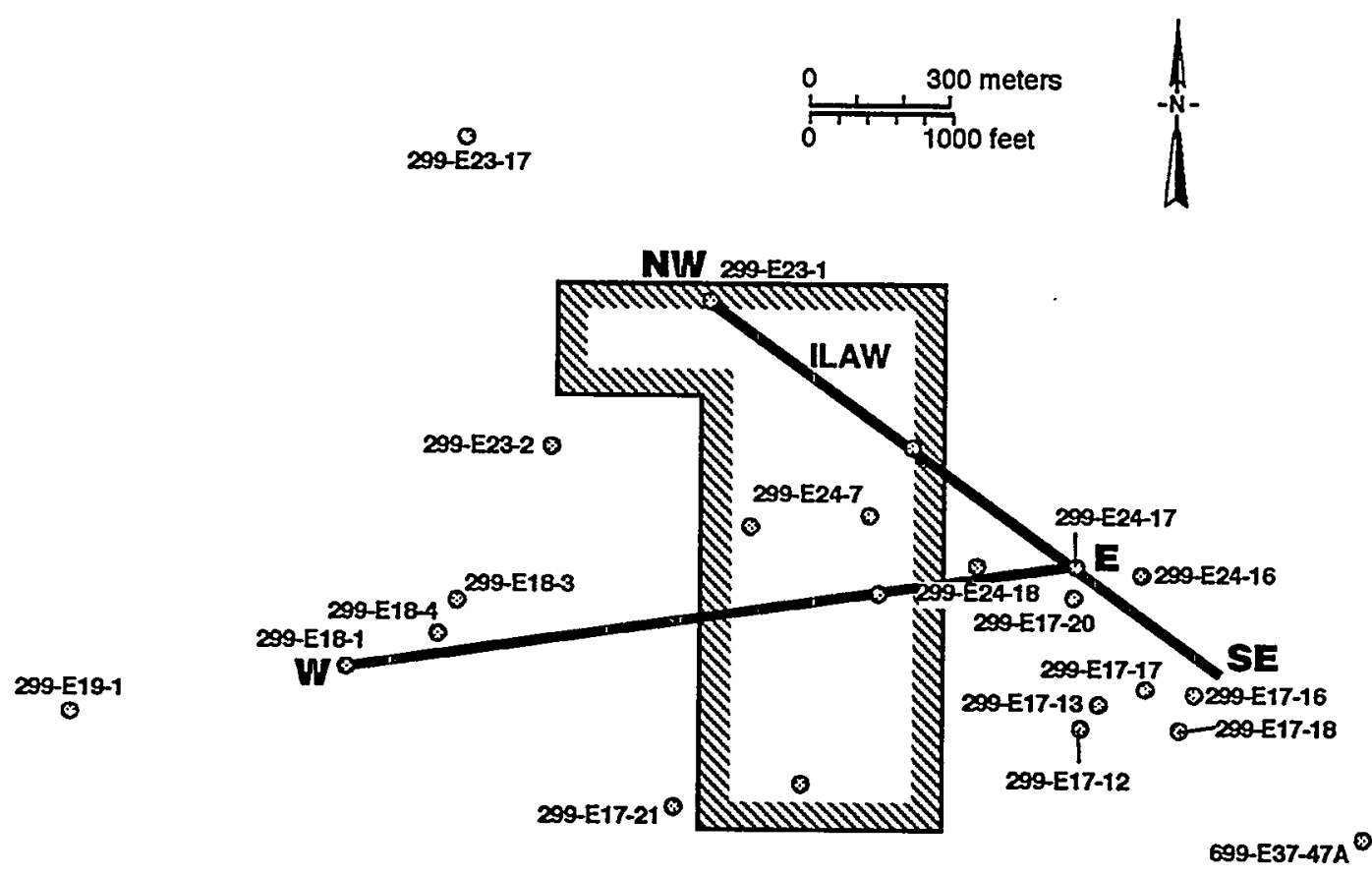

299-E13-14

0

O299-E13-10

G89110108.1

Figure C.4. Map of the New ILAW Disposal Site Showing the Locations of the Summary Cross Sections 


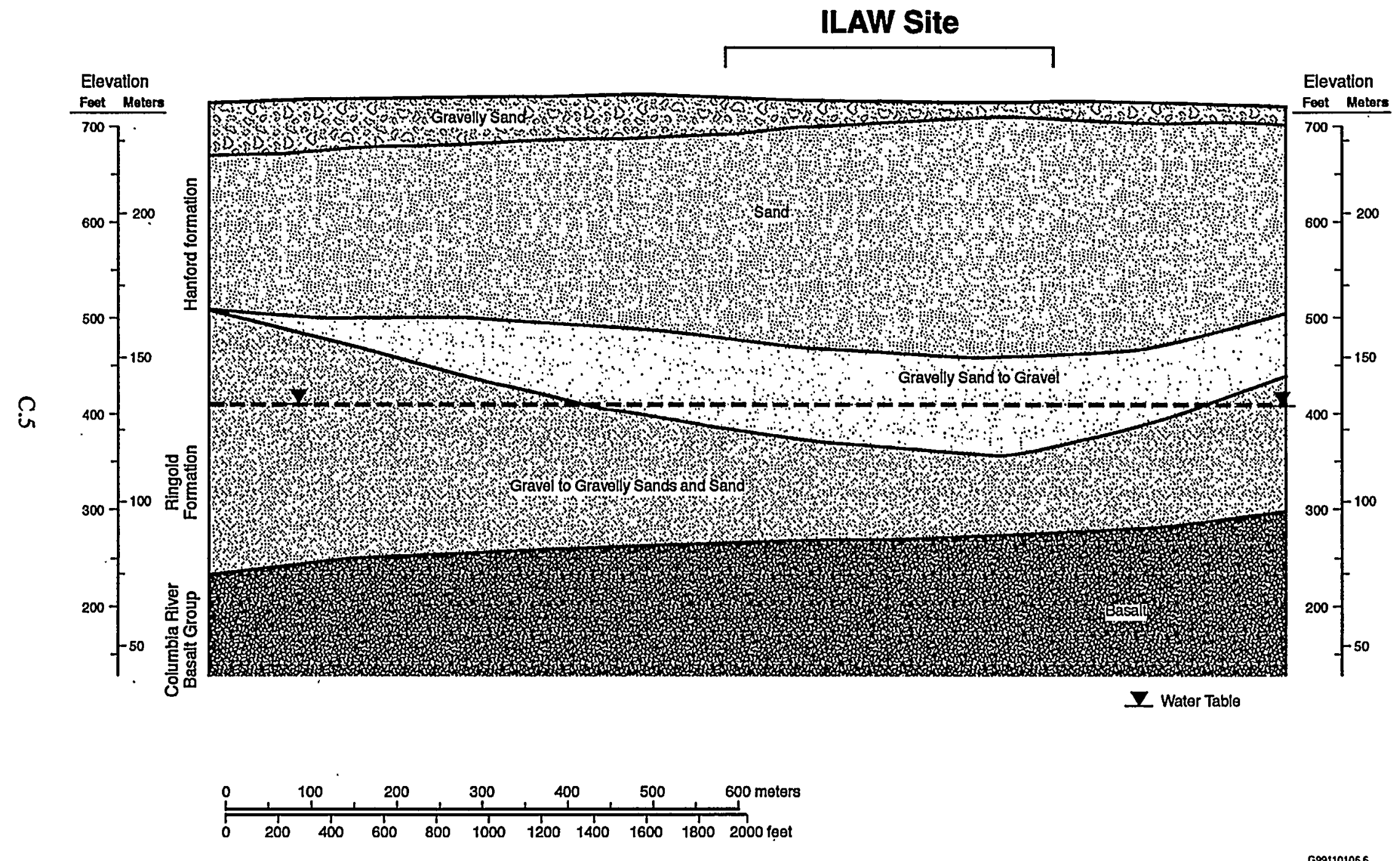

Figure C.5. Summary Diagram of a West to East Cross Section for the New ILAW Disposal Site 


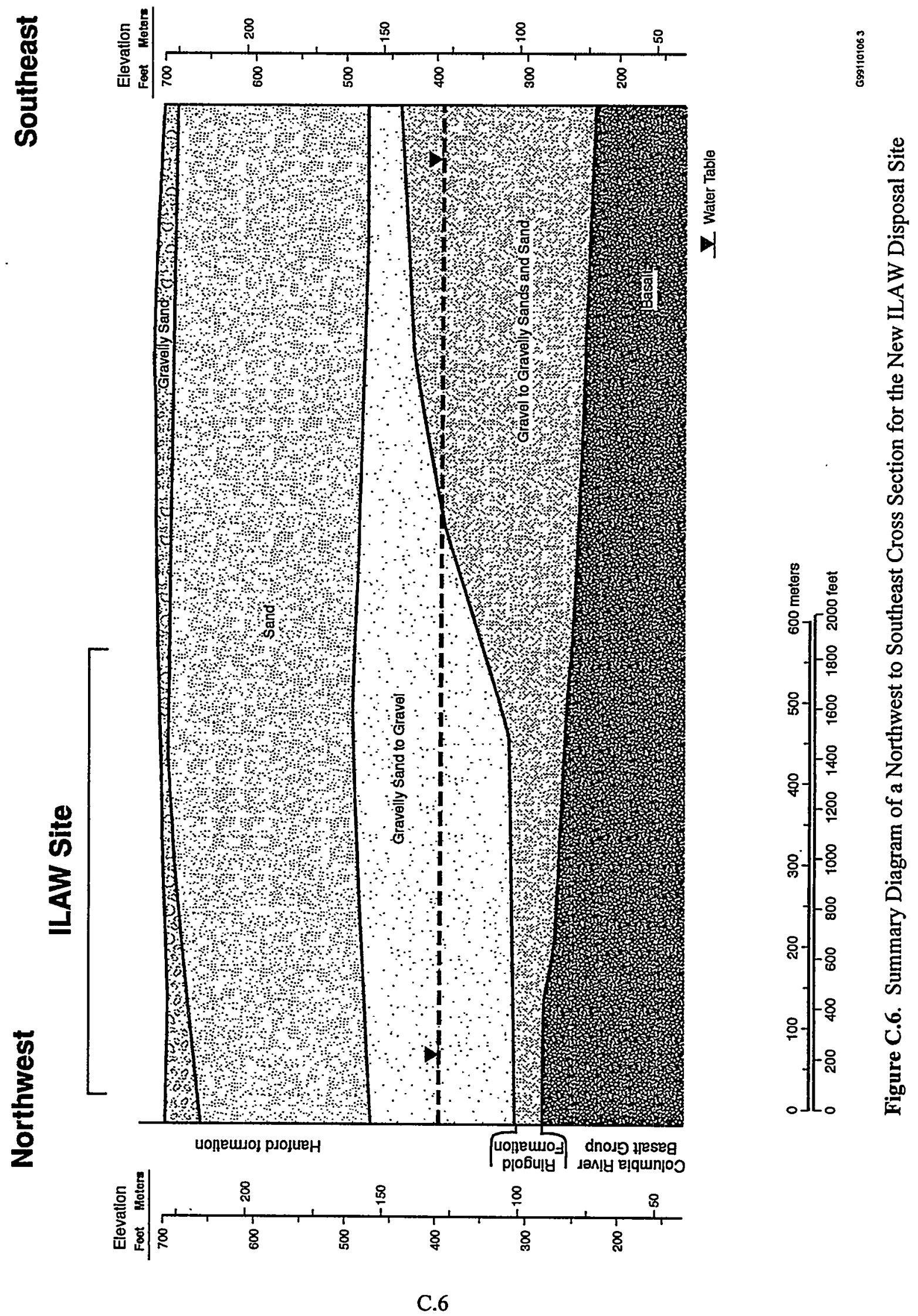




\section{Distribution}

No. of

Copies

ONSITE

3 Bechtel Hanford, Inc.

BH Ford

$\mathrm{H} 0-21$

GA Jewell (2)

4 Fluor Daniel Northwest Services, Inc.

EJ Freeman

B4-43

$\mathrm{R}$ Khaleel

FM Mann

B4-43

$\mathrm{H} 0-22$

RJ Puigh

B4-43

4 Lockheed Martin Hanford Corporation

DA Burbank

S4-45

KC Burgard

AJ Knepp

RW Root

S4-45

$\mathrm{H} 0-22$

R2-53
No. of

Copies

2 Office of River Protection

CA Babel

H6-60

PE LaMont

H6-60

16 Pacific Northwest National Laboratory

RW Bryce

K6-75

MJ Fayer

K9-33

R Holdren

K6-81

DG Horton

K6-81

CT Kincade

K9-33

BP McGrail

K9-81

PD Meyer

BPO

RJ Serne

K6-81

SP Reidel

K6-81

Information Release Office (7)

K1-06

Distr.1 